\title{
Article
}

\section{Currency Policies and Legal Development in Colonial New England}

\author{
Claire Priest ${ }^{\dagger}$
}

\section{CONTENTS}

I. THE EFFECTS OF CURRENCY SCARCITY ON MARKETS AND

THE LAW

A. Barter, the Cost of Transacting, and Market Development

B. Public and Private Responses to Currency Scarcity in Colonial Massachusetts Prior to the Issuance of Public Currency.

C. Colonial Judicial Remedies Before Widespread Public Currency Circulation

D. Assessing the Costs of Monetary Scarcity ...............................1335

1. The Limitations of Money Substitutes

2. Economics Scholarship on Colonial Economic Growth......1339

II. Public PAPER Money ISSUANCE AND ITS EFFECT ON LITIGATION PATTERNS

A. The Demand for Greater Currency.

$\dagger$ Samuel I. Golieb Fellow, New York University School of Law. I wish to thank Christine Desan, Robert Gordon, Timothy Guinnane, Ronald Michener, Edmund Morgan, Carol Rose, Susan Rose-Ackerman, Christopher Tomlins, James Whitman, and Sean Wilentz for providing valuable comments and encouragement. I am also grateful for the contributions of seminar participants at NYU's Legal History Colloquium, the John M. Olin Summer Fellows program at Yale Law School, and the American Society for Legal History. The John M. Olin program at Yale and the Samuel I. Golieb program at NYU provided generous financial support for this project. Finally, I thank Renato Mariotti and all those at The Yale Law Journal who provided editorial assistance. 
B. The Structure of Colonial Paper Money Policies

C. The Legal and Economic Effects of Government Control over Monetary Stability

1. The Effect of Currency Issuance on the Colonial Money Supply

2. Colonial Monetary Policy and the Potential for Currency Crises.

3. Currency Policies, the Common Law, and Contractual Relations

4. Currency Policies and Individuals' Litigation Strategies ... 1357

III. CURRENCY POLICIES IN MASSACHUSETTS, 1710-1750.

A. Expanding the Money Supply, 1710-1725. 1360

B. The Currency Crises of the 1720s and 1730s and Their Resolution. 1368

IV. A CuRRency Policy EXPlanation of TRENDS In DEbT LITIGATION 1384

A. The Modernization Analysis of Debt Litigation Data 1384

B. Currency Crises and Debt Litigation Volume 1386

V. COlONIAL LAW AND THE ECONOMY: A REINTERPRETATION 1396

A. The Centrality of Currency Policy and Politics to Debt Litigation Trends...

B. Reassessing the Role of Courts in Promoting Economic Growth.

1. Nominalism

2. The Colonial Court System and Economic Recession 1402

VI. CONCLUSION 1404 
Legal historians have long emphasized the role courts played in promoting the development of a market society in colonial America. Indeed, judicial enforcement of debt agreements and other contractual obligations has been viewed as the central and most important aspect of government promotion of the nascent colonial economy. Nevertheless, there has been substantial disagreement about the extent of colonial economic development and about colonists' attitudes toward markets and commercialism. Judges have been characterized in contrasting terms as bulwarks of pre-industrial cultural norms impeding development or as knowing catalysts of commercial transformation. Legal historians, however, have universally (if implicitly) agreed that focusing on the court system and judicial decisionmaking is the best means of assessing the role of law in economic development.

An emphasis on judicial decisionmaking has led legal historians to accept two underlying assumptions about the relationship of law to the development of markets. First, colonial law has been generally perceived as rooted in inherently local cultural norms and local market conditions. When the principal source of law is considered to be the decisions imposed by judges on disputing parties, "law" in a more composite sense is naturally characterized as emerging endogenously out of relationships between individuals within local communities. Legal historians therefore principally see the impact of law on economic development as the combined effect of many individual decisions relating to the economic matters emerging within particular communities.

Legal historians' focus on judicial decisionmaking has also led to an assumption that the law adjusts in some natural way to changing economic and cultural climates. According to this view, lawsuits are an indirect reflection of prevailing cultural norms and market conditions. Judges adapt the law as those norms and conditions change. The court system therefore fulfills an institutional role of ensuring that the law keeps pace with societal transformation. As described in greater detail below, however, colonial legal historians have characterized the court system not merely as keeping pace with changing conditions. According to current legal historical scholarship, whether by formalistically requiring parties to adhere to their commitments and thereby promoting economic advance and the extension of a market society, or by resolving disputes in a matter consistent with communitarian values, judges actively promoted an agenda in harmony with local preferences. Colonial courts are therefore typically depicted as optimally satisfying the legal needs of local communities.

The most prominent description of the insular and community-oriented base of colonial law is in Morton Horwitz's The Transformation of American Law, 1780-1860. Horwitz emphasizes the centrality to eighteenth-century law of limitations on market activity such as the just 
price and usury doctrines, contracts involving transfers of property rather than monetary payments, and damages based on equity and fairness rather than on satisfying expectations. ${ }^{1}$ Emphasizing the prevalence of litigation based on direct property exchanges, Horwitz concludes that the law reflected undeveloped markets and a community-oriented society in which goods "were usually not thought of as being fungible.... [and] [e]xchange was not conceived of in terms of future monetary return." 2 To Horwitz, colonial law reflected a pre-industrial communitarian mindset, "essentially antagonistic to the interests of commercial classes," 3 in which the justification for contractual obligation was "the inherent justice or fairness of an exchange." ${ }^{4}$ Colonial law applied by judges, therefore, reflected the values associated with pre-industrial, agrarian societies. ${ }^{5}$ In this respect, Horwitz contrasts the judicial doctrine of the eighteenth century with that of the nineteenth century, when judges began using common-law decisions to promote capitalist values and a market economy. ${ }^{6}$ With regard to both the colonial period and the nineteenth century, however, Horwitz portrays the law as harmoniously synchronized to advance prevailing cultural norms and preferences regarding economic advance.

More recently, legal historians such as Bruce Mann and Cornelia Dayton have examined colonial court records and have developed a vastly different interpretation of colonial law and its relation to market activity. By focusing on legal practice and litigation trends, rather than strictly on

1. See Morton J. Horwitz, The Transformation Of American Law, 1780-1860, at $160-73$ (1977).

2. Id. at $162-63$.

3. Id. at 167 .

4. $l d$. at 160 .

5. The scholarship supporting the conception of colonial law as static first gained prominence with ROSCOE POUND, THE FORMATIVE ERA OF AMERICAN LAW (1938), and includes GRANT Gilmore, The Ages of American law (1977); William E. Nelson, Americanization of THE COMMON LAW (1975) [hereinafter NELSON, AMERICANIZATION]; and WILLIAM E. NELSON, Dispute and CONFLict Resolution in Plymouth COUNTY, MASSACHUSETTS, 1725-1825 (1981) [hereinafter NELSON, DISPUTE AND CONFLICT RESOlUTION]. See also Charles Fried, 93 HARV. L. REV. 1858, 1864-66 (1980) (reviewing P.S. ATIYAH, THE RISE AND FALL OF FREEDOM OF CONTRACT (1979)) (criticizing Atiyah for overemphasizing the extent to which judges valued community consensus above individuals' promises in the seventeenth and eighteenth centuries); Robert W. Gordon, Book Review, 51 N.Y.U. L. REV. 686, 687-88 (1976) (reviewing NELSON, AMERICANIZATION, supra) (criticizing Nelson for characterizing colonial law and society as static and consensus-oriented).

6. According to Horwitz, "[o]nly in the nineteenth century did judges and jurists finally reject the longstanding belief that the justification of contractual obligation is derived from the inherent justice or faimess of an exchange." HORWITZ, supra note 1, at 160.

In a well-known article, A.W.B. Simpson questioned the extent to which judges applied doctrines that seemingly restricted market activity such as, for example, just price and usury, in a way that actually limited commercial activity. See A.W.B. Simpson, The Horwitz Thesis and the History of Contracts, 46 U. CHI. L. REV. 533, 535-42 (1979). Simpson also challenged the merits of Horwitz's conclusion that colonial courts failed to award expectation damages in contract litigation. Id. at 547-61. Simpson's critique was widely accepted, but was chiefly negative, providing no affirmative explanation of colonial law. 
doctrine, these historians conclude that civil law in colonial New England was neither static nor reflective of antimarket communitarian beliefs. According to Mann and Dayton, seventeenth-century civil law derived from economic conditions of predominately household subsistence production and market transactions that were largely confined within relatively insular communities. In the seventeenth century, judges tailored their decisions to individual litigants and to the relationship between the parties underlying the transaction. By the first half of the eighteenth century, however, economic advances made these informal procedures untenable. In response to commercialization, judges began to apply more formal and predictable legal rules, which provided greater certainty to contractual promises and generated, as a result, even further economic development. The law, therefore, modernized in the New England colonies during the first half of the eighteenth century in response to, and to promote, the expansion of markets and the growth of contractual promises between citizens of different communities. ${ }^{\text {? }}$

Bruce Mann's and Cornelia Dayton's theories of legal development in eighteenth-century New England have been widely accepted and endorsed by a generation of legal historians. Although a relatively recent addition to legal scholarship, this "modernization theory" ${ }^{8}$ of legal change parallels a

7. See CORnelia Hughes DaYTon, WOMEN BEFORE THE BAR: GENDER, LAW \& SOCIETY IN CONNECTICUT, I639-1789 (1995) [hereinafter DAYton, WOMEN BEFORE THE BAR]; PETER Charles Hoffer, Law and People in COlonial America (rev. ed. 1998); BRuCE H. ManN, NEIGHBors AND StRangers: LaW AND COMMUNity IN EARLY CONNECTICUT (1987); Peter Charles Hoffer, Honor and the Roots of American Litigiousness, 33 AM. J. LEGAL HIST. 295 (1989); Deborah A. Rosen, Courts and Commerce in Colonial New York, 36 AM. J. LEGAL HIST. 139 (1992) [hereinafter Rosen, Courts and Commerce]; Deborah A. Rosen, The Supreme Court of Judicature of Colonial New York: Civil Practice in Transition, 1691-1760, 5 LAW \& HIST. REV. 213 (1987) [hercinafter Rosen, Civil Practice in Transition]; Cornelia Dayton, Law and Disputing in Commercializing Early America, 87 MICH. L. REV. 1538 (1989) Lhereinafter Dayton, Law and Disputing] (reviewing MANN, supra). For a discussion of the relation between Mann's, Dayton's, and Rosen's works and earlier scholarship characterizing colonial law as static, see Rosen, Civil Practice in Transition, supra, at 213-14; and James A. Henretta, 53 WM. \& MARY Q. 793, 796 (1988) (reviewing MANN, supra).

8. Cornelia Dayton characterizes Mann's Neighbors and Strangers as "a sustained argument for the emergence by 1750 of a legal system geared to serve the interests of a commercial (or capitalist) political economy." Dayton, Law and Disputing, supra note 7, at 1546. Dayton's Women Before the Bar focuses on the changing nature of women's role in the legal system during the colonial and early republican periods. Her analysis of the relationship between economic development and legal modernization, however, largely complements Mann's analysis in Neighbors and Strangers. Although with some reservations, Mann describes his own argument as a modernization theory, arguing that

the importance of a rational, predictable legal system to economic activity is a staple of the modernization literature. One need not address the simplistic and misleading question of whether Connecticut was undergoing modernization in the eighteenth century to accept that mercantile transactions can proceed more smoothly and on a grander scale when the impediment of individuality is removed...

An expanding economy requires that individual transactions be governed by generally applicable rules. ... Rational economic exchange requires the assurance that 
longstanding body of scholarship among historians that describes the decline in community in colonial New England as the society transformed from one oriented around close-knit, cooperative Puritan towns to one with extended markets and market values. The decline in community also coincided with increased immigration, geographical mobility, and the growth of urban centers. ${ }^{9}$

The central evidence supporting the legal modernization theory consists of widely accepted statistics relating to the volume and substantive content of litigation. These statistics show that, in the first half of the eighteenth century, the total volume of litigation rose exponentially, far above increases in population. These statistics also show that the increase in litigation is largely attributable to an increase in the volume of cases based on debts - suits to reclaim money, goods, and services. ${ }^{10}$ The modernization hypothesis claims that this increase in litigation volume resulted from growing commercialization and the use of more formal credit instruments that resulted in an increase in the number of debt obligations entered into and, as a result, an increase in the number of debt cases to reclaim money owed on those obligations. " Proponents of the modernization theory show

like cases will be treated alike. To provide that assurance, general rules override the individuality of particular cases and force them into a common mold.

MANN, supra note 7, at 36. Deborah Rosen refers to her argument as a modernization theory, arguing: "[T]he American legal system underwent steady change in response to economic developments well before the alleged modernization of the nineteenth century.... In the eighteenth century, legal practice changed in order to make sure that law served the interests of commercial people and a commercial economy." Rosen, Courts and Commerce, supra note 7, at $139-40$.

9. For examples of historical scholarship establishing the "decline of community" theory, see Richard L. Bushman, From PURITAN to YankeE: Character and the SOCIAL ORDER IN CONNECTICUT, 1690-1765 (1967); KENNETH A. LOCKRIDGE, A NEW ENGLAND TOWN: THE FIRST HUNDRED YEARS (expanded ed. 1985); and sources cited in CHRISTINE LEIGH HEYRMAN, Commerce and Culture: The Maritime Communities of Colonial MassachusetTs, 1690-1750, at 6 n.4 (1984).

10. Reference to "debt" cases in this Article follows the practice of other colonial historians and includes all cases brought to reclaim money or goods (but not rent or other land cases), which means that actions on "Debt" have been grouped with actions on "Case." Colonial courts used a more informal variation of the English writ system. According to Zechariah Chafee, who studied the cases of the Suffolk County Court in Massachusetts in the period from 1671 to 1680, there was "no apparent differentiation between debt and case .... [S]uits on debts are called case or debt without any apparent reasons for the distinction." Zechariah Chafee, Jr., The Suffolk County Court and Its Jurisdiction, Introduction to 29 PUBLICATIONS OF THE COLONIAL SOCIETY OF MASSACHUSETTS, RECORDS OF THE SUFFOLK COUNTY COURT 1671-1680: PART I, at xxxviii-xl (1933) [hereinafter RECORDS OF THE SUFFOLK COUNTY COURT 1671-1680: PART 1].

11. Mann attributes the increase in litigation rates to rising indebtedness accompanying economic growth:

Commercial expansion brought with it-indeed, rode the crest of - a rising tide of indebtedness... The sharp increase in uncontested debt actions in the 1730 s... underscored not only the massive increase in indebtedness but also the acceptance of indebtedness as a necessary cost of doing business.

MANN, supra note 7, at 62. Dayton, largely following Mann, clearly specifies the correlation between economic growth and increasing civil litigation. According to Dayton, "[t]he proliferation of notes-and other written instruments such as bonds and bills-fueled an 
that the legal system was becoming more formal and predictable by demonstrating increases in the percentage of uncontested debt cases, pleadings based on purely technical issues, as well as a decline in the use of juries. In essence, modernization theory scholars contend that rising litigation accompanied a process of legal formalization and was a function of economic advance and commercialization.

The acceptance of the modernization theory has led to a partial rejection of Horwitz's and others' conclusion that colonial law was static in comparison to the more development-oriented law of the nineteenth century. Although the modernization theorists do not dispute that communitarian values may have influenced judicial decisionmaking in the seventeenth century, they identify the eighteenth century-not the nineteenth century - as the key moment when the legal system began promoting the expansion of markets. Much of the success of the modernization theory has derived from its seemingly superior ability to explain colonial litigation data. The Horwitz hypothesis of dominant communitarian norms does not explain, for example, the remarkable rise in

enormous rise in debt litigation across New England, an expansion that far outstripped population growth.... In essence, the burgeoning volume of uncontested debt cases represented the capitalization of the New England economy." DAYTON, WOMEN BEFORE THE BAR, supra note 7, at 90, 102. Rosen states similarly that "[i]n colonial New York, debt litigation increased as a direct consequence of the growth of New York's economy. Economic growth led to an increased number of commercial transactions, which meant an increased number of potential disputes-and potential lawsuits." Rosen, Courts and Commerce, supra note 7, at 150; see also BuSHMAN, supra note 9, at 136 (relating Connecticut's exponential litigation increases of the eighteenth century to economic expansion).

Although each author emphasizes the relationship between the rise in the volume of debt litigation and economic growth and commercialization, each acknowledges that colonial economic development varied over time and that other factors also affected litigation rates. Both Mann and Dayton, for example, mention that in 1740, the year of the highest volume of debt litigation in Connecticut, agricultural prices dropped, which brought debtors to courts in high numbers. See DAYTON, WOMEN BEFORE THE BAR, supra note 7, at 90 . According to Mann, the decline in farm prices in 1740 led to a "decade of economic distress" which resulted in abnormally high litigation volumes. See MANN, supra note 7, at 62-66. Rosen addresses the issue of recession and litigation volume in greater detail, recognizing that high litigation rates were often attributable to a "fluctuating economic climate," when defendants in debt suits sued down the "chain of credit, with each person unable to pay his own debts until his own debtors paid him." Rosen, Courts and Commerce, supra note 7, at 146. According to the modemization theory, however, these changes reflect only variations from the general trend of an increase in litigation volume paralleling an expanding economy. See DAYTON, WOMEN BEFORE THE BAR, supra note 7, at 90-91; Rosen, Courts and Commerce, supra note 7, at 150-51.

A second explanation attributes the changes in litigation rates to courts' social function beyond their role as a source of stability in the economy. One common element of the arguments of Mann, Dayton, and Rosen is the contention that litigation increased as other, communityoriented enforcement mechanisms, such as town governments and churches, lost legitimacy and authority. See DAYTON, WOMEN BEFORE THE BAR, supra note 7, passim; MANN, supra note 7, at chs. 4, 5; Rosen, Courts and Commerce, supra note 7, at 144; see also DAVID THOMAS KonIG, LAW AND SOCIETY IN PURITAN MASSACHUSETTS: ESSEX COUNTY, 1629-1692, at 188 (1979) (describing the role of colonial courts in providing social cohesion and equilibrium in seventeenth-century Massachusetts); $c f$. Hoffer, supra note 7, at 297-98 (arguing that the central determinant of colonial debt litigation was a plaintiff's sense of honor). 
the volume of debt litigation and the shift to litigation based on more formal credit instruments during the first half of the eighteenth century.

Some aspects of the modernization theory, however, do not seeni to be thoroughly worked out, especially with respect to the interpretation of the legal data. First, as discussed below, economic scholarship raises considerable doubts about the extent to which New England experienced substantial economic growth during the first half of the eighteenth century, which supports Horwitz's view that market activity was suppressed during this period. Second, according to the modernization theory, the law became steadily more formal and predictable at the same time that civil litigation increased exponentially. This relationship is peculiar because under steady economic conditions, the adoption of more predictable legal rules should decrease, rather than increase, litigation, and out-of-court settlements should increase because of greater predictability. ${ }^{12}$ It follows that to sustain the modernization explanation of litigation increase-that economic advances led to an increase in the volume of credit agreements entered into, and a proportionate increase in debt defaults-requires a showing of economic growth and commercialization at levels high enough to account for an absolute increase in litigation despite a reduction in the litigation rate because of greater legal predictability. To date, no modernization scholar has attempted this proof. As a consequence, there are reasons to question the relationship among each of the features of the modernization hypothesis-economic growth leading to greater legal predictability and resulting in exponential increases in litigation.

This Article argues that there are serious methodological and substantive limitations in the explanation given by colonial legal historians of the legal system's impact on economic expansion and the emergence of a market-oriented society. The principal weakness of legal historical scholarship on the relationship between law and colonial economic development has been a failure to recognize the legislature's powers over economic conditions and its essential role in affecting the nature of contractual relationships, the quantity of litigation, and even the court system's function in promoting, or limiting, economic growth. This Article proposes that the legal and economic changes of the first half of the eighteenth century in New England did not emerge endogenously out of individuals' obligations, shaped by local conditions and enforced in local courts. The principal factor driving the legal changes of the first half of the eighteenth century was the effort by colonial legislatures to expand their powers and to gain control over the economy by issuing the first paper

12. See George L. Priest \& Benjamin Klein, The Selection of Disputes for Litigation, $13 \mathrm{~J}$. LEGAL STUD. 1 (1984). 
currencies $^{13}$ and by taxing in paper currency. The central purpose of the Article is to show the interconnection between legislatures' use of currency policy to expand government power, the types of contractual obligations entered into on a widespread basis, and the litigation explosions occurring during the currency crises of the period. Examining these relationshipsamong currency policies, the nature of contracting, and litigation trendsleads to a different assessment of the role of the colonial legal system in the economy of New England than that of prior scholarship. An emphasis on currency policy reveals that colonial law should not be characterized by either the assumption that the most important sources of law emerged locally, or that the law continually adapted optimally to satisfy preferences of local communities.

Colonial governments began issuing paper money, in the form of bills of credit, in the period from 1690 to $1710 .{ }^{14}$ The seventeenth-century colonial economy was plagued by an extreme scarcity of a circulating medium of exchange. Indeed, at various times, the economy was close to operating on a barter basis. Currency scarcity had tremendous implications for the nature of government, the forms in which individuals transacted, and the structure of the society. First, the lack of a circulating currency seriously limited government power. New England colonial governments in the seventeenth century, for example, were often required to tax in commodity currencies, such as corn and wheat, because the citizenry lacked other currencies with which to satisfy their tax obligations. ${ }^{15}$ Taxing in a commodity imposes a variety of inefficiencies on a government. ${ }^{16}$ Its effect was to limit the extent to which government institutions could finance and realistically expand the scope of their operations.

Second, the scarcity of cash was profoundly important in determining the types of contractual obligations entered into by individuals. Barter exchange is difficult. ${ }^{17}$ Colonial citizens adopted many mechanisms to surpass direct barter: First, they used what might be called "money substitutes," such as commodity money-corn, wheat, or tobacco

13. For the purposes of this Article, "currency" and "money" are defined as devices that operate as a means of exchange, a mode of payment, and a standard of value. This Article examines many types of "currency" and "money": gold and silver coins from Europe; public bills of credit issued by colonial governments; and commodity money and credit devices such as book accounts and promissory notes (which used other currencies as a standard of value). This Article focuses on the importance to legal change of the issuance and circulation of bills of credit, first issued by the Massachusetts government in 1690 . These bills of credit, and those of other colonies, are called "public currency" or "paper money."

14. Massachusetts issued the first paper bills of credit in the colonies in 1690. Connecticut and New Hampshire issued their first bills of credit in 1709, and Rhode Island in 1710. LESLIE V. Brock, THE CURRENCY OF THE AmERICAN COLONIES, 1700-1764: A STUdY IN COLONIAL FINANCE AND IMPERIAL RELATIONS 18, 35 (1975).

15. See infra text accompanying notes 56-65.

16. See infra note 174 and accompanying text.

17. See infra notes $35-43$ and accompanying text. 
functioning as cash. In addition, colonial laborers were often compensated in kind-such as by the use of "shop notes." 18 Indeed, the prevalence during this period of slavery and labor relations structured as property relationships, rather than wage contracts, during this period was very likely a consequence of the scarcity of cash. A final principal way colonists surpassed the problems of barter was through the creation of networks of debt relationships, such as book accounts, which functioned as a system of tabs, allowing members of a community to buy and sell goods from each other without using cash. The prevalence of these practices suggests that the economy should be characterized as generally consisting of "quasi-barter," rather than pure barter conditions. Even quasi-barter, however, limited the potential for economic exchange and constrained individuals to be involved in local, intracommunity economic relationships.

Finally, quasi-barter conditions had an important effect on the overall social structure of the society. In relation to the cash economy that was to develop later, the seventeenth- and early eighteenth- century economy was an environment of high transaction costs. The more difficult and costly it is to make exchanges in the market, the more goods will be produced within a household or a community. ${ }^{19}$ As is described in greater detail below, the forms of transacting colonial citizens developed to surpass pure barter often led to insularity within small communities. Being constrained to quasibarter exchanges therefore greatly suppressed economic activity and reinforced an economic system based upon intracommunity exchanges and localism.

The complications of an economy without money have been overlooked by legal historians. The older school of colonial legal scholarship - exemplified by Horwitz's account-instead focused on a set of phenomena that might be better regarded as the effects on the legal system of a scarcity of sufficient currency. Horwitz, for example, recognizes the lack of monetary provisions in contractual obligations, but explains them as deriving from a colonial "premarket" ideology. Understanding the difficulties of exchange under a barter regime and the ways in which colonial merchants ameliorated those difficulties, however, suggests a more materialist explanation of the communitarian aspects of early colonial society. Intracommunity contractual relationships were reinforced by economic conditions and were not necessarily driven by (although in some areas plausibly coincided with) a pre-industrial, communitarian mindset. New England citizens involved in the market, however, aggressively advocated the adoption of private and governmental

18. See infra note 270 and accompanying text.

19. See infra text accompanying notes $41-42$. 
currencies as early as $1682,{ }^{20}$ expecting that widespread availability of currency would lead to economic advance. As a consequence, the evidence Horwitz describes would change once currency became more widely available.

The expense of war efforts in the late seventeenth and early eighteenth centuries led the colonial governments for the first time to print paper money in the form of bills of credit. Thus, after 1710, colonial economies transformed from being based principally on a mix of barter, money substitutes, and coin exchanges to operating with widespread use of government paper money. ${ }^{21}$ The circulation of paper money had a tremendous effect both on the power of colonial legislatures and on market conditions within the colonies. Printing money vastly increased colonial governments' ability to finance operations. Governments could raise funds far more quickly by printing and issuing bills, and then by levying taxes payable in the bills, than by earlier forms of finance. Taxing in bills of credit was far more efficient than taxing in corn or wheat.

Paper money also had profound effects on credit conditions and the forms of contractual obligations colonists used. Widespread availability of cash dramatically lowered the costs of transacting, which increased the number of exchanges possible and led to greater market development and specialization. The widespread availability of paper money also changed the nature of contractual relationships throughout the colonies. It was no longer necessary to employ barter exchanges or the forms of debt instruments that had substituted for hard currency. The colonial legislatures' enactment of the first currency policies both increased legislative power and promoted commercialization. Expanding government power and market growth seemingly coincided.

Despite the evident benefits of a stable currency, however, currency policy in New England was highly uncertain. Each colony's annual determination of the volume of public currency in circulation reflected a struggle within colonial assemblies, which faced pressure from part of the public to print more bills, and conflicting pressure from English and New England merchants who desired a stable currency of high value to satisfy English import debts. The colonies, of course, were not autonomous: The English Board of Trade and Parliament repeatedly attempted to stabilize the value of colonial currencies, which often increased uncertainty and

20. Andrew McFarland Davis, Introduction to 1 COLONIAL CURRENCY REPRINTS, 16821751, at 1 (Andrew McFarland Davis comp., 1910) [hercinafter Colonial CurRency REPRINTS]. 1682 is the year of publication of a plan describing and advertising the first privately backed currency instituted in the colonies. The plan was conceived in 1649. [REV. JOHN WOODBRIDGE], SEVERALS RELATING TO THE FUND (n.p. 1681), reprinted in I COLONIAL CURRENCY REPRINTS, supra, at 108, 110. This bank is discussed infra notes 147-151 and accompanying text.

21. See infra text accompanying notes 168-172. 
fluctuations in currency values because of conflicts with colonial policies. Indeed, in New England, the tensions within the elected, representative assemblies, and between those assemblies and the English-representatives of a foreign sovereign promoting a mercantilist agenda-led to policies that created disastrous uncertainty. Moreover, because colonial bills of credit passed throughout New England at par, the policies of neighboring governments at times led to currency instability despite the efforts of individual colonial governments. The resulting currency policies and the combined effect of various colonial governments' currency issues led in New England to periods of extreme depreciation (currency gluts), and periods of currency scarcity when people were forced to revert to barter exchange.

Colonial currency policies had a direct effect on trends in litigation and, more generally, on the court system's impact on economic development. Periods of currency crisis greatly affected individuals' litigation strategies. First, high levels of inflation (currency depreciation) had a direct effect on the value of all debt obligations within the colony. ${ }^{22}$ Debtors had an incentive to postpone payment to benefit from declining currency values. ${ }^{23}$ Fluctuations in the value of currency similarly affected the costs of litigation which, in the colonial period, principally took the form of legislatively determined court and lawyers' fees. Court fees impose a cost on litigation; inflation, not to say high inflation, lowered the costs of litigating in real terms, reducing those costs. ${ }^{24}$ Second, colonial currency crises generated deep economic recessions, leading creditors to sue to reclaim debts in advance of other creditors, thereby causing "chains of debt," in which each person sued his debtors and then his debtors' debtors, and so on. ${ }^{25}$ All of these factors influenced individuals' litigation strategies-and, therefore, influenced the creation of law as applied by courts. These factors have been ignored, however, by colonial historians.

The creation of law through individual judicial decisions therefore cannot be adequately understood without an appreciation of the complex relationship between currency policies and economic conditions, and the resulting impact of those conditions on litigation volume. Indeed, in contrast to the modernization theory, a more thoroughgoing analysis of debt litigation reveals that the volume of litigation in the colonies did not rise gradually during the first half of the eighteenth century, as might be expected if litigation levels were the result of growing commercialization

22. See infra text accompanying notes $186-193$.

23. See infra text accompanying notes 222-223.

24. See Claire Priest, Note, Colonial Courts and Secured Credit: Early American Commercial Litigation and Shays' Rebellion, 108 YALE L.J. 2413, 2424-39 (1999); infra text accompanying note 338 .

25. See infra text accompanying notes 193-194, 224-229. 
and general economic growth. Rather, there were specific periods during which the volume of litigation rose exponentially, and separate periods when it sharply declined. The periods of high litigation volume occurred at times of economic crisis in Massachusetts, Connecticut, and other colonies, and were triggered by the state of their public currencies.

Close examination of litigation trends reveals a correlation between currency policies and litigation volume: As this Article shows, the exacerbation of currency problems in the years 1726 to 1730,1733 to 1734 , and 1738 to 1741 in New England corresponds to volatile and increasing litigation volume during those periods. Colonial legal historians have focused on the years from 1730 to 1750 as the principal period of increasing legal modernization. This Article shows, in contrast, that currency scarcity or instability required many engaged in trade to revert to barter transactions and caused widespread financial hardship and economic stagnation-exactly the reverse of modernization.

The currency policy approach also suggests a different interpretation of the judiciary's impact on the economy during the first half of the eighteenth century. As this Article shows, the legal tender laws in force during the times of currency crisis in Massachusetts permitted debtors to repay in paper money the nominal value designated in contracts, despite any depreciation (reduction in currency value) or appreciation (increase in currency value) of the bills. ${ }^{26}$ During periods of extreme depreciation, debtors defaulted on their debts to delay repayment in the hope that they would benefit from continued depreciation and would be able to pay in money of a lesser value. Contemporary accounts indeed suggest that the rise in uncontested debt cases of the 1730s and 1740s represents not legal modernization, but debtors' attempts to delay repayment by forcing their creditors to obtain judgments against them. ${ }^{27}$ Until the legislature enacted a law in 1742 requiring that judges index judgments in response to changes in the value of the bills of credit, the judiciary could play no role in remedying Massachusetts's economic crises. ${ }^{28}$ Thus, examination of the currency events of the 1730 s and 1740 s suggests a very different conclusion from modernization theorists' characterization of the eighteenth-century judiciary as reforming legal process to promote economic advance. Rather, by enforcing legal tender laws enacted by the colonial assembly, Massachusetts law did very little to improve, and may have worsenedhowever involuntarily-already poor economic conditions.

A lack of understanding of the importance of currency policies in shaping contractual relations and motivating litigation has led legal scholars

26. See infra text accompanying notes 186-190.

27. See, e.g., infra text accompanying note 338 .

28. See infra text accompanying notes 306-309. 
to overlook crucial aspects of the interrelation of economic, legal, and political developments of the colonial period. First, legislative policy is essential to an understanding of the role of law in promoting or limiting economic development. Economic conditions within the colonial economy were importantly determined by political events, including the escalating tensions between the colonies and England. Indeed, a focus on currency policies reveals that the prevalence of book accounts-perhaps the most "local" of transactions-was dependent upon decisions made by Parliament in England. The direct correlation between currency policies and litigation shows that a historical approach that emphasizes judicial responses to relationships between individuals and community valuesystems is an approach that loses sight of the importance of broader political issues on local events.

Indeed, colonial legal historians have ignored the specific ways in which the politics of currency policy affected colonial legal developments. For example, when the Royal Government required the colonies to recall outstanding bills of credit in the 1730s and 1740s, colonists burdened by the subsequent recession attempted to remedy the problem by establishing: a Land Bank and a Silver Bank that issued private currencies. The subsequent British dismantling of these banks, in order both to respond to the demands of British creditors and to limit the political autonomy of colonial governments, led to a general uproar and a minor insurrection in western Massachusetts. John Adams later claimed that the "act to destroy the Land Bank scheme raised a greater ferment in this province than the Stamp Act did." ${ }^{29}$ Sentiments of this nature have had no role in current colonial legal history. Yet, the political fervor of the time provides additional support for one of this Article's central arguments-that politics on a national, as well as a colony-wide, level was vitally important to local litigation events and the relation of courts to the economy.

Second, the assumption that judges continually adapted the law to satisfy local preferences optimally is misguided. The court system's impact on economic development is far more problematic in light of its management of the litigation crises occurring during periods of currency crisis. During skyrocketing inflation, the requirement of the law that debtors could satisfy their monetary obligations with a payment of the nominal value - and the unwillingness of judges to amend the doctrine-may have worsened credit conditions. ${ }^{30}$ Moreover, the absence of a good system of priority lending rules in the colonial period led to a higher litigation volume

29. 4 JOHN ADAMS, Novanglus: Or, A History of the Dispute with America, from Its Origin, in 1754, to the Present Time, in THE WORKS OF JOHN ADAMs 3, 49 (Charles Francis Adams ed., Boston, Charles C. Little \& James Brown 1851) (emphasis added).

30. For a discussion of the advantages and disadvantages of the "nominalism" doctrine, see infra text accompanying notes 360-363. 
than would otherwise have been the case ${ }^{31}$ Each of these features of the court system requires further scrutiny.

Part I of this Article examines economic conditions in Massachusetts ${ }^{32}$ preceding the issuance of government paper money and shows how the lack of a widely available currency shaped contractual relations and commercial litigation. Part II describes the nature of private and public support for the issuance of government paper money and how dependence upon that paper money affected Massachusetts's litigation volume. Part III examines the currency crises of the 1730s and early 1740s. Part IV demonstrates the empirical correlation between currency policies and litigation volume revealed by data from the Plymouth, Massachusetts, County Court of Common Pleas. Part V then reassesses the role of the court system in promoting economic growth during the first half of the eighteenth century in New England.

\section{THE EFFECTS OF CURRENCY SCARCITY ON MARKETS AND THE LAW}

To understand the links between monetary and litigation crises in colonial times, it is necessary to understand the nature of the colonial economy before the issuance of paper money and how quasi-barter conditions suppressed commercial relations. This Part analyzes the ways in which early New England's economic conditions were reflected in the prevailing economic practices, contractual arrangements, and judicial remedies of a society in which little hard currency was available for use in transactions. Section I.A examines generally the aspects of barter economies that suppress commerce. Section I.B discusses the ways that economic practices in colonial New England reflected an environment in which money was scarce. It analyzes the types of trading practices used to increase the number of possible exchanges and, more relevant to litigation, the importance and prevalence of borrowing practices when hard currency was not available. Section I.C describes how judicial remedies in commercial litigation reflected an environment of scarce cash. Finally,

31. See infra note 366 and accompanying text.

32. Bruce Mann's and Comelia Dayton's works focus on Connecticut during the first half of the eighteenth century. This Article examines the currency policies in Massachusetts during the period from 1710 to 1742 . The determinants of litigation in Massachusetts are likely to be very similar to those affecting litigation in other New England colonies (though political events differed throughout the colonies). The economies of Connecticut and other New England colonies were closely linked commercially with Massachusetts, because Boston was the principal port of export. Though each colony determined its own currency policy, bills of credit of the New England colonies were accepted at par as a medium of exchange throughout. See infra note 172. This Article focuses on a currency crisis instigated by currency policies imposed by England on Massachusetts and New Hampshire, but Connecticut's economy was so closely linked with that of Massachusetts that Connecticut's currency (and as this Article argues, its litigation levels as well) would have been affected similarly, though perhaps not exactly simultaneously. 
Section I.D examines the costs of reliance on endogenous money substitutes and the systemic effects of a lower volume of exchange and of undeveloped markets on economic and cultural conditions. Section I.D also analyzes economics scholarship on colonial economic growth rates, suggesting the real effects of monetary scarcity on economic activity. Then, Part II shows how economic crises causing reversion to barter led to periods of dramatically increasing litigation volume.

\section{A. Barter, the Cost of Transacting, and Market Development}

It is unlikely that any economy, other than the truly primitive, has ever operated purely on barter. This Section analyzes the difficulties of pure barter in order to clarify the problems facing colonial citizens who participated in the market economy. The following Sections, then, describe in greater detail how colonial governments responded to this monetary scarcity and how colonial citizens surpassed the constraints of pure barter.

Monetary conditions directly affect the costs of transacting. In the aggregate, through multiplied costs imposed on individual transactions, monetary conditions greatly influence the degree of specialization and the development of markets. Pure barter creates essentially two impediments to economic activity that have been emphasized in the economic literature: the need for a "double coincidence of wants," and information problems associated with an economy without money prices. Money is commonly defined in the economic literature as any item that serves as a medium of exchange, a unit of account, and a store of value. ${ }^{33}$ The existence of money, whether in the form of fiat money, ${ }^{34}$ commodity money, or enforceable debt obligations, immediately solves many of the problems associated with barter and advances a process of change toward a developed market economy.

The first way in which pure barter suppresses economic exchange is defined in the economic literature as the need for a "double coincidence of wants" - that exchanges can occur only when individuals want to exchange the precise goods they possess and can agree on the value, quantity, and time to make the exchange. ${ }^{35}$ There are three components of

33. See, e.g., Bennett T. McCallum \& Marvin S. Goodfriend, Demand for Money: Theoretical Studies, in THE NEW PALGRAVE: MONEY 117 (John Eatwell et al. eds., 1989).

34. Fiat money is money that has no intrinsic value, such as paper money. In contrast, specie is currency with intrinsic value, such as gold, which can be exchanged whether in the form of coin or melted down.

35. See, e.g., W. Stanley Jevons, Money and the Mechanism of Exchange (London, D. Appleton 1875); Abhijit V. Banerjee \& Eric S. Maskin, A Walrasian Theory of Money and Barter, 111 Q.J. ECON. 955, 956 (1996); Ross M. Starr, The Structure of Exchange in Barter and Monetary Economies, 86 Q.J. ECON. 290, 290 (1972). According to Jevons, "There may be many people wanting, and many possessed those things wanted; but to allow an act of barter, there must be a double coincidence, which will rarely happen." JEVONS, supra, at 3. 
the double coincidence problem. One component might be called "incommensurability": The goods of one of the potential parties to a transaction cannot be divided to match the value of the goods of the other by quantity or according to value. As an obvious example, the value of a pig may be equal to more than five, but less than six, live laying hens. The existence of money, particularly in small denominations, solves this problem by permitting payment according to the precise value of each good. Under barter, on the other hand, many exchanges will not occur or will be subject to additional costs of exchange because there is no way to compensate more precisely for value or quantity.

Another component of the double coincidence problem might be called the "incompatibility of wants": One person may want to trade his or her pig for hens, but may find only a person with no hens but who is willing to take the pig in exchange for cloth or wood. This incompatibility may not defeat the transaction, but it will only go forward if the owner of the pig is willing to act as a middleman and believes a subsequent deal can be made trading cloth or wood for hens. ${ }^{36}$ In a fully developed economy, money eliminates this problem; in a thin economy, such as colonial New England, money reduces it.

A final double coincidence problem involves "synchronization." ${ }^{37}$ Parties may want to make an exchange, but may not have the exact goods desired by the other at the exact time the other wants to make the exchange. Money, in any form, solves this problem since money can be held (saved) for future use or, in the case of enforceable debt obligations, promised for the future, allowing parties themselves to control the timing of consumptive exchanges.

The second difficulty emphasized in economics that tends to suppress trade under conditions of pure barter is the high cost of attaining information $^{38}$ about goods or labor. Unlike under a monetary economy, where a price establishes a good's value in relation to all other goods, under barter, the value of the goods in an exchange is conditioned by what is being exchanged-no general value is established. Knowledge concerning the value of a good depends upon a community's ability to disseminate

36. Karl Brunner and Allan $\mathrm{H}$. Meltzer argue that a lack of a medium of exchange leads to use of "transaction chains" (multiple-stage transactions) to reduce the marginal costs of exchanging. Karl Brunner \& Allan H. Meltzer, The Uses of Money: Money in the Theory of an Exchange Economy, 61 AM. ECON. REV. 784, 788 (1971).

37. Id. at $785 \&$ n. 4 .

38. The term "information" is used in a general sense to mean any facts relevant to the value of the product. The "information problem" in undeveloped markets refers to, for example, problems conveying the value of inherent features of the product or its use, problems of spreading information about the relative values of particular goods (for example, prices in Boston or prices in neighboring rural towns), and information problems regarding supply and demand (for example, knowledge that another boat is arriving with similar goods or that the boat was shipwrecked). 
information about previous exchanges of that good; thus, the marginal cost of acquiring information about goods is reduced according to the frequency with which a group exchanges those goods. ${ }^{39}$ Uncertainty about value limits incentives to improve the quality-and thus increase the marginal valueof goods. In an undeveloped market, the person in possession of a good with uncommon features may know its value, but may have no way of proving the value to others and obtaining its true value in an exchange. ${ }^{40}$

A barter economy with thin markets can be characterized as one in which transaction costs are extremely, perhaps in many cases prohibitively, high. The double coincidence problem and the lack of price information impose a "cost" on each transaction. The aggregate costs of individual transactions in a society directly influence the development of markets and the volume of contractual relations. Higher transaction costs lead to less specialization and reduce the benefits of comparative advantage. The more difficult and costly it is to make exchanges in the market, the more goods will be produced within a household or community. Indeed, just as Ronald Coase explained with regard to the existence of firms, households and communities will produce on a self-subsistence basis wherever the additional costs of trading on the market exceed the diseconomies of internal household or community production. ${ }^{41}$ Household subsistence production, however, limits the degree to which individuals can channel their energies into specialized tasks because of the diverse work required to produce the full set of necessary foods and goods. Phrased differently, the prevalence of subsistence production reflects the limitations of the ability of markets to benefit from specialization. Indeed, as emphasized by Adam Smith in The Wealth of Nations, the division of labor is limited by the extent of the market, and the extent of the market is constrained by the costs of exchange. ${ }^{42}$

39. Brunner \& Meltzer, supra note 36 , at 786 .

40. Brunner and Meltzer argue that the principal problem of barter is "the uneven distribution of information." Id.

41. According to Coase:

The main reason why it is profitable to establish a firm would seem to be that there is a cost of using the price mechanism... [A] firm will tend to expand until the costs of organizing an extra transaction within the firm become equal to the costs of carrying out the same transaction by means of an exchange on the open market or the costs of organizing in another firm.

R.H. COASE, The Nature of the Firm, in THE FIRM, THE MARKET, AND THE LAW 38, 44 (1988).

42. 1 Adam SMITH, AN INQUiRy inTo THE Nature and CaUSES OF THE WEalth OF Nations 21 (Edwin Cannan ed., Univ. of Chi. Press 1976) (1776). In 1729, Benjamin Franklin described how currency allows market development and specialization, particularly focusing on the importance of currency to the development of a larger population of wage laborers, who would work for money rather than laboring for their own subsistence. Coin scarcity in New England, he argued, led to difficulties in recruiting wage laborers because the value of their labor often exceeded the amount a laborer wanted to receive in subsistence goods. According to Franklin, "A Plentiful Currency will encourage great Numbers of Labouring and Handicrafts Men to come and Settle in the Country, by the same Reason that a Want of it will discourage and 
The level of transaction costs, therefore, directly affects market activity and the volume of contractual relations in a society. In addition, profitseeking activity is more limited in an economy with high transaction costs. In a barter economy, the potential for "profits" in each transaction is limited by the ability to trade the excess of goods acquired beyond one's needs (the profits) for more desirable goods through the market. The limited profit-making ability in barter similarly constrains the extent of borrowing and lending. Receiving goods as payment for debts is feasible chiefly where there exists a market for those goods. The higher the transaction costs, the lower the profits gained from obtaining goods that must be sold. Thus, the level of credit available can be predicted to be far lower in an economy with high transaction costs, such as barter, than in a fully monetized economy with a stable currency. ${ }^{43}$ As is shown below, the unavailability of gold and silver coins for typical domestic transactions led colonists to adopt money substitutes that alleviated the problems of barter and encouraged greater commercialization. The next Section describes transactional adjustments to monetary scarcity more systematically.

\section{B. Public and Private Responses to Currency Scarcity in Colonial Massachusetts Prior to the Issuance of Public Currency}

Before the widespread circulation of government paper money, Massachusetts had what might be regarded as a mixed coin/barter economy. During the seventeenth and early eighteenth centuries, silver and gold coins circulated throughout the colonies, but they were scarce and valued too highly to be used in most domestic transactions. ${ }^{44}$

drive them out." [BENJAMIN FRANKLIN], A MODEST ENQUIRY INTO THE NATURE AND NECESSITY OF A PAPER CURRENCY (Philadelphia, n.p. 1729), reprinted in 2 COLONIAL CURRENCY REPRINTS, supra note 20, at 335, 339. Wage laborers were viewed as necessary for production of cash crops-and, thus, for an extension of market production. Wage laborers are one example of specialization resulting from greater currency availability, but it was believed that currency would lead to market development and specialization over a broader scope.

43. The fact that transaction costs are generally lower in a monetized economy does not preclude the possibility of incidents when direct exchanges for goods are preferable to cash exchanges. Infra note 179.

44. When Massachusetts issued its first paper money, the most common coins in circulation were the four forms of Spanish "pieces of eight": the Peru (or light piece) and the heavy piecesthe Mexico, pillar, and Seville. BRoCK, supra note 14, at 5 \& nn.2 \& 7. Coins that appear in cases of the Suffolk County Court, 1671-1680, are pieces of eight (Spanish), gilders, and stivers in wampum value (Dutch), wampum (see below), French livres, markes and nobles (German), the coins of Barbados, and English Sterling. Chafee, supra note 10, at xvii, lxxvi; see also Frederick K. Beutel, Colonial Sources of the Negotiable Instruments Law of the United States, 34 ILL. L. REv. Nw. U. 137, 139-40 \& n.29 (1939) (listing other colonial currencies). The first legal currency in Massachusetts was wampum, a polished shell long used as a medium of exchange by Native Americans, which was made legal tender in 1643. See Wampampeag (1643), THE General LaWS AND LiberTies of MASSACHUSETtS COLONY 154 (rev. ed., Samuel Green 1672) [hereinafter GENERAL LAWS], reprinted in THE COLONIAL LAWS OF MASSACHUSETTS (Boston, Rockwell \& Churchill 1889). Wampum served well as a currency when traders were able 
Two features of colonial political and economic life increased the value of gold and silver. First, European governments in the seventeenth and eighteenth centuries embraced the mercantilist belief that policies adopted to prohibit the export and encourage the import of coins would provide a more readily available medium of exchange and easier finance of government expenditures (through taxation of coins). On these grounds, the English Parliament prohibited all export of English Sterling to the colonies as of $1695 .{ }^{45}$ During the same period, Portugal prohibited exportation of gold and silver and Spain levied a three-percent tax on all gold and silver exports. ${ }^{46}$ Because of the high demand for currency, gold and silver coins of many nations circulated internationally despite the prohibitions, but the relative scarcity that resulted from these policies increased the coins' value, as Adam Smith observed, by "the expence of smuggling." 47

Balance of trade is a second reason for the high value of coins in the New England colonies. Imports from England exceeded New England's exports, and coins were generally required as balance-of-trade payments to English creditors. ${ }^{48}$ Gold and silver coins were most commonly used in

to discern its quality accurately. According to Curtis Nettels, the highest quality wampum was used exclusively in trade between discriminating Native Americans and colonial traders. In contrast, poor quality wampum flooded the markets of New England towns and was passed off into church coffers and to tax collectors. In Massachusetts, the flooding of the market with low quality wampum led to such high levels of inflation that its legal tender status was canceled in 1661. Id. (noting date of repeal); CURTIS PUTNAM NeTTELS, THE MONEY SUPPLY OF THE AMERICAN COLONIES BEFORE 1720, at 211-12 (1934) (describing the impetus behind repeal); ARTHUR NUSSBAUM, A HISTORY OF THE DOLLAR 6-7 (1957) (same).

45. JOSEPH ALBERT ERNST, MONEY AND POLITICS IN AMERICA, 1755-1775: A STUDY IN THE CURRENCY ACT OF 1764 AND THE POLITICAL ECONOMY OF REVOlution 20 (1973); NETTELS, supra note 44, at 162; NUSSBAUM, supra note 44, at 7 .

46. 2 SMITH, supra note 42 , at 17.

47. Id.

48. BROCK, supra note 14 , at 3, 30; ERNST, supra note 45, at 20; BRAY HAMMOND, BANKS AND POLITICS IN AMERICA 14 (1957); NETTELS, supra note 44, at 162-78; NUSSBAUM, supra note 44, at 7,31 ; see also JOHN J. MCCUSKER, MONEY AND EXCHANGE IN EUROPE AND AMERICA, 1600-1775, at 116-17 (1978) (describing the regularity with which colonists reached the "specie export point" - the point at which the cost of paying debts to English creditors in London bills of exchange became higher than that of exporting specie directly, which led to an outflow of specie). This view has been challenged. E.g., Roger W. Weiss, The Issue of Paper Money in the American Colonies, 1720-1774, 30 J. ECON. HIST. 770 (1970). Weiss argues that the "balance of trade" explanation of currency scarcity in the colonies is inadequate because England suffered from a similar scarcity of coins during the same period, though England had a favorable balance of trade generally. Id. at 773-74. In addition, Weiss argues that, if the problem were a shortage, there would have been deflation-a general price decline-to compensate. Id. at 773 , 775. My own view is that Weiss's second argument, which follows a commonly accepted quantity theory of money, may wrongly assume that the colonies were a "closed economy" with respect to circulating coins. In a closed economy, one wouid expect the price level to reflect the quantity of money in circulation. In the seventeenth and eighteenth centuries, however, the market for gold and silver coins was highly international; it included Europe, the Caribbean Islands, and South America. The New England colonies, which represented merely a small portion of the overall market, were therefore likely to be price-takers with respect to the price of coins. Put differently, the value of money was likely to be established in international markets, rather than in colonial markets alone. 
international transactions. Nonetheless, coins circulated with sufficient frequency that transactions were generally recorded by a monetary standard-in Sterling denominations-even when no money exchanged hands. The use of pounds, shillings, and pence as units of account remedied a principal problem of barter, the lack of a price mechanism, permitting substantial circulation of information about prices and market conditions throughout the colonies.

The early history of colonial coinage was largely influenced by conflicts between the policy decisions of colonial governments, which wanted to remedy the lack of currency, and the English government, which was not willing to cede control over monetary policy to the colonial governments, hoping to provide security for English loans to the colonies. In the seventeenth century, colonial assemblies attempted to remedy the scarcity of coins by adopting policies that overvalued Spanish pieces of eight and other foreign coins (in relation to Sterling) in order to attract these monies into their respective colonies. ${ }^{49}$ As an example, in 1652 the Massachusetts government began reminting coins of other nationscreating pinetree shillings consisting of the "bullion, plate, and spanish coyn" that people brought in to be melted down and recoined-rewarding with profit those who participated in the recoining. ${ }^{50}$ Massachusetts simultaneously passed a law, like those of England and Portugal, prohibiting the export of money and permitting the confiscation of all money attempted to be exported as well as of all visible property used in an export attempt. Massachusetts appointed "Searchers" to examine and search the persons, packages, and ships of all those leaving the colony. ${ }^{51}$ Such laws were largely unsuccessful in the long run, however, in part because other colonies enacted similar laws, diminishing through competition the effectiveness of any single colony's efforts. ${ }^{52}$

These Acts were repealed under pressure from the English government, in part because of the concern that colonial mints might adopt policies that

49. NETTELS, supra note 44, at 231-234.

50. Money (1652), General LaWS 117, 117, reprinted in The Colonial Laws of MASSACHUSETTS, supra note 44; NETTELS, supra note 44, at 170-71, 236-37.

51. Money (1652), General Laws 117, 118, reprinted in THE Colonial Laws of MASSACHUSETTS, supra note 44. This law resulted in at least one judicial decision. Stanberry \& Harris's Money (Jan. 26, 1675), in RECORDS OF THE SUFFOLK COUNTY COURT 1671-1680: PART I, supra note 10, at 559. The court determined that it was not proved that Stanberry and Harris were trying to take money out of the colony, and ordered their money returned to them. Id. According to Nettels, Massachusetts's ban on exportation of pinetree shillings was not effective. NETTELS, supra note 44, at 171.

52. BROCK, supra note 14, at 233; MCCUSKER, supra note 48, at 118-19. Following the quantity theory, Brock argues that these measures could have had only temporary effects because an influx of coins would lead to a rise in prices to reflect the actual value of the coins. E.g., BROCK, supra note 14, at 9. 
would encourage the exportation of silver from England to America. ${ }^{53}$ The Massachusetts mint was shut down by the English in $1684 .{ }^{54} \mathrm{~A}$ proclamation issued by the English Privy Council in 1704, followed by a Parliamentary Act in 1708, required a standardization of the value of currencies in relation to Sterling-that is, a uniform exchange ratethroughout the North American colonies. This Act would have eliminated colonial governments' ability to draw coins from other colonies, but the colonial governments refused, or were unable, to enforce it. ${ }^{55}$

Colonial governments also attempted to remedy the problem of monetary scarcity by designating particular commodities as money for the purposes of payment of public debts. ${ }^{56}$ Commodity money was most prevalent in those colonies that specialized in exporting particular staple crops. Virginia and Maryland, for example, relied almost exclusively on tobacco-their principal staple crop-as currency. ${ }^{57}$ New England had no equivalent staple crop but, at various times, designated farm products such as beef, wheat, pork, corn, flax, and hemp-typically called "country pay" - as commodity money. ${ }^{58}$ The success of a commodity money depended upon the good's lack of perishability and the stability of supply and demand for the good. Colonial governments, for example, accepted taxes paid in tobacco or corn because it was a product many people grew, with a relatively steady demand and, therefore, a secure resale market. ${ }^{59}$

53. See NETTELS, supra note 44 , at 173 . For a more detailed discussion of colonial governments' attcmpts to attract gold and silver coins and the efforts to standardize the value of coins in relation to Sterling by the English Board of Trade and Parliament, see generally BROCK, supra note 14, at 130-67. In 1682, Massachusetts again responded to the scarcity of coins by enacting a law making Spanish pieces-of-eight legal tender. According to the Massachusetts General Court, the law was passed "As an expedient to keep Money in the Countrey," because "Commerce and Trade is very much obstructed" by the scarcity of coins. Pieces of Eight (1682), SEVERAL LaWs MADE AT THE SECOND SESSION OF THE GENERAL COURT, Oct. 11, 1682, at 94, reprinted in THE COLONIAL LAWS OF MASSACHUSETTS, supra note 44, at 294.

54. NETTELS, supra note 44 , at 174 \& n.47, 236-37.

55. The 1708 Act for Ascertaining the Rates of Foreign Coins in Her Majesty's Plantations in America limited the value of a piece of eight to six shillings. ERNST, supra note 45, at 23. Contemporary accounts suggest, however, that the Act was not effective: Subsequent Royal Instructions claim that the Act "has not been observed as it ought to have been in many of his Majesty's colonies and plantations in America." Coinage Act and Instructions on Currency To Be Observed (1740), reprinted in 1 LEONARD WOODS LABAREE, ROYAL INSTRUCTIONS TO BRITISH COLONIAL GOVERNORS, 1670-1776, at 214 (1935); see also BROCK, supra note 14, at 148-67 (discussing the ineffectiveness of the act).

56. Gold and silver are "commodities" in that they are used for consumptive purposes beyond money. For the purposes of this Article, however, the term "commodity money" refers to nonmetallic commodities used for both consumptive and monetary purposes. For a review of various forms of commodity money used throughout the American colonies, see NETTELS, supra note 44 , at $202-28$.

57. Id. at 208.

58. $I d$.

59. E.g., Charges Publick (1646), General Laws 22, 24-25, reprinted in The Colonial LAWS OF MASSACHUSETTS, supra note 44 (permitting taxes to be paid in corn). On colonists' complaints regarding the inefficiency of taxing in com, see infra note 174 . 
Colonial governments, however, had tremendous problems in ensuring that minimum standards of quality were maintained. Producers of commodity money had an incentive to pass off the worst crop of tobacco or the worst corn to tax collectors or to unsuspecting creditors. Indeed, the Massachusetts government's 1643 experiment to vest wampum, a polished shell used as a medium of exchange by Native Americans, with the status of legal tender failed after the citizenry began paying taxes in poor-quality wampum. ${ }^{60}$ In later years, colonial governments that authorized commodity money typically hired officers to determine whether or not crops met certain minimal standards before certifying them to be used as money. ${ }^{61} \mathrm{By}$ 1730, Virginia had developed the most sophisticated inspection system of commodity money in the colonies in the process of establishing a tobacco note currency. ${ }^{62}$ Such systems were more difficult to establish in New England, which lacked a single, dominant staple crop. ${ }^{63}$ Although the New England colonies permitted locally produced goods to be used to pay taxes, commodity money never satisfied the demand for a medium of exchange as it had in Virginia. ${ }^{64}$ Indeed, four years after it first issued paper money, Massachusetts enacted a law forbidding the use of commodity money in payment of taxes. ${ }^{65}$

These various efforts-in retrospect-failed to create a sufficient monetary base to allow any colony to operate on a basis closely resembling cash exchange. In response to the uncertain availability of money, colonial traders developed a unique set of transactional practices, generally of two

60. See supra note 44 .

61. See, e.g., NETTELS, supra note 44 , at 212-14.

62. Individuals brought their tobacco to public warehouses, where government officials destroyed tobacco not making the grade, and issued "tobacco notes," based on the estimated value of the tobacco, which were used in all public and private payments and which circulated as the principal medium of exchange. A.G. ROEBER, FAITHFUL MAGISTRATES AND REPUBLICAN LAWYERS: CREATORS OF VIRGINIA LEGAL CULTURE, 1680-1810, at 96-100 (1981); JAMES H. SOLTOW, THE ECONOMIC ROLE OF WILLIAMSBURG 112-15 (1965).

63. Commodity money was, however, extremely important to Connecticut's economy, and the colony established systems of valuing the goods for tax purposes. In 1654, for example, the colony of New Haven enacted a law providing that:

[In] every plantation ... there shall be a viewer of come, that in case of differrence may judg, whether it be well dressed and merchantable or no, which man is to be chosen by each plantation, and shall bee under oath to judg faithfully when called to it, and is to be paide for his time spent and paines therein by him whose corne is faulty, or who unnecessarily occasions the trouble.

2 RECORDS OF THE COLONY OR JURISDICTION OF NEW HAVEN, FROM MAY, 1653, TO THE UNION 98, 154 (Charles J. Hoadly ed., Hartford, Case, Lockwood, and Co. 1858). In 1694, this system was extended throughout Connecticut to value both pork and grain. 2 THE PUBLIC RECORDS OF THE COLONY OF CONNECTICUT 224 (J. Hammond Trumbull ed., Hartford, F.A. Brown 1852); see NETTELS, supra note 44, at 212.

64. See SOLTOW, supra note 62 , at 114.

65. See NETTELS, supra note 44 , at 209. Massachusetts eventually reversed its stance on accepting goods as taxes during periods of severe monetary scarcity subsequent to the circulation of paper money. Infra note 233, 272 and accompanying text. 
types, that can be defined as "money substitutes": privately negotiated commodity money and enforceable debt obligations. ${ }^{66}$

To understand the colonial economy, it is necessary to understand how goods and services were exchanged to take advantage of specialization and comparative advantage. Borrowing, either in relations of mutual indebtedness, or in unilateral agreements, was the standard way economic transactions occurred, whether in daily transactions within the context of a small town, or in large-scale deals such as those arranging for imports from the Caribbean or England. As explained below, the vast majority of civil lawsuits in the seventeenth and eighteenth centuries related to problems arising out of creditor-debtor relations under these borrowing systems, which were adapted to the scarcity of money. ${ }^{67}$

The transactional practices using what have been referred to here as "money substitutes" have been interpreted in contrasting terms by Morton Horwitz and the modernization theorists. Both Horwitz and the modernization theorists characterize the lending schemes prevailing before the first government paper monies as signaling a communitarian, premarket value system in which the normative basis for exchanges and contractual arrangements was community stability and fairness, rather than commercial advancement and profit-seeking. The weakness of this interpretation, however, is its failure fully to appreciate the problem of currency scarcity within the colonial economy in the seventeenth and early eighteenth centuries. While seventeenth-century lending practices may coincide with cultural values reflecting more primitive market conditions, ${ }^{68}$ these practices may also indicate the limitations placed on people who sought profits and who desired economic advance, but who were constrained by the lack of currency to intracommunity lending practices. Horwitz's theory that colonists maintained a "title theory of exchange," in which goods were neither viewed as fungible nor thought of in terms of monetary values, suffers from a similar weakness. While it might be the case that the lack of currency reduced the extent to which goods were conceived of in monetary terms, the frequency with which contractual arrangements involved goods-rather than money-can also be explained as a value-neutral adaptation to an environment with scarce cash.

The first colonial money substitute was privately negotiated commodity money. ${ }^{69}$ Although publicly sanctioned commodity money was not as

66. For the purposes of this Article, the term "money substitutes" describes practices that are adopted to serve the purposes of money, but are not the issuance or minting of a currency by private or public institutions. The colonial money substitutes described here served as a medium of exchange and a store of value, but not a unit of account.

67. Infra notes 103-104 and accompanying text.

68. Infra notes 120-122 and accompanying text.

69. See W.T. BAXTER, THE HOUSE OF HANCOCK: BuSINESS IN BOSTON, 1724-1775, at 21 (1945). For an excellent review of the practices that developed to alleviate the problems of the 
prevalent in New England as in the South, New Englanders routinely used commodities as a medium of exchange in private contracts. Examining the Hancock records, for example, W.T. Baxter found many examples of times when basic staple goods, such as a particular type of fish, were continually exchanged back and forth between people involved in trade. ${ }^{70}$ These fish assumed the role of money and represent the "small change" of the transaction. Similarly, farmers typically used "country pay" to pay back debts to lenders. The problems of publicly sanctioned commodity money were avoided within the private sector, because the designation of what would serve as commodity money and the value of particular shipments were negotiated with each transaction. ${ }^{71}$

Colonial merchants also used commodity money in their practice of dealing in "assortments" of goods, accepting payment in a wide variety of goods and services and then trading the goods off for the highest value. According to Bernard Bailyn:

To be a merchant in Boston in 1660 meant to be engaged, wholesale and retail, in the exchange of a great variety of goods, to be ready to accept payment in all sorts of unexpected commodities and currencies.... Versatility was one of the keys to success; to specialize was to decline. ${ }^{72}$

Baxter, who examined the papers of the Hancock business, similarly found:

[G]oods that were exchanged seem at times to have been selected in the oddest way. Their variety and unexpectedness are often startling. Thus, for instance, Henchman repaid a carpenter for repair-work not only with books, ... but also with a gun, cider, barrels of beef, pencils, candles, hogs, molasses, and wood. ... [A] transaction involving imposing quantities of merchandise may be closely followed by the purchase of a trifle such as a few pennyworth of cloves; identical kind [sic] of goods are transferred

colonial economy, see $i d$. at ch. 2 , which describes the practices of the Hancock family business in the eighteenth century.

70. See id. at 23 .

71. As mentioned, pounds, shillings, and pence, in colonial values, were accepted as the common units of account. Thus, it was unnecessary for commodities to be priced in terms of every commodity money. Goods that functioned as commodity money were themselves priced in terms of pounds, shillings, and pence. Economists argue that the possibility of private commodity money means that the technical difficulties of barter cannot be the only reason for a governmentissued, widely circulating currency. Commodity money can, in many cases, be more stable than public currency. See, e.g., Banerjee \& Maskin, supra note 35, passim; cf. Starr, supra note 35, at 291.

72. Bernard Bailyn, The New England Merchants in the Seventeenth Century 100 (3d prtg. 1982). 
backwards and forwards between the same merchants; and ... the names of third parties appear frequently. ${ }^{73}$

Although Baxter views these transactions as arbitrary, exchanging a wide variety of goods - and exchanging goods for goods of disparate types-can be seen as methods of approximating precise compensation in a context of cash scarcity.

A second money substitute preceding the circulation of paper money was widespread borrowing by means of legally enforceable promises. The basic money supply is most commonly defined as including items that can be used directly in transactions, such as paper money, gold and silver coins, other commodity money, and checking accounts (today referred to as $M_{1}$ ), plus assets that can be liquidated relatively quickly, such as savings account deposits, mutual fund investments, and stock holdings (referred to as $\left.M_{2}\right)^{74}$ Colonial debt obligations, which were either payable on demand or by a specified date, and which could be liquidated (although not without a lawsuit) were an important component of what one might describe as the colonial $M_{2}$.

The most common borrowing practice before the widespread circulation of paper money was the "book account" system, a mechanism recognized in the courts as a means of recording indebtedness between traders or within a market community. ${ }^{75}$ Individuals kept "book" records (like a tab) of goods others took on credit, recording debts in pounds, shillings, and pence, although no money was exchanged. The system worked as people in a community established accounts with each other, taking goods and services on credit, and gradually reciprocating with different goods and services over time. When a sufficient number in a town permitted debts on book, people were able to make daily "purchases" depending on their needs, even without the benefit of a common currency.

Cases from the Inferior Court of Common Pleas in Plymouth, Massachusetts, ${ }^{76}$ for example, demonstrate that book accounts were used for transactions ranging from "sundry goods," to the balance due for "boots and shoes," 77 for that "remaining due for a yoke of a young

73. BAXTER, supra note 69, at 18-19 (citation omitted).

74. For a discussion of the components of the money supply see, for example, PaUL A. SAMUELSON \& WiLliam D. NORDHAUS, ECONOMICS 227-30 (13th ed. 1989).

75. See BAXTER, supra note 69, at 17-21.

76. The Inferior Court of Common Pleas had original jurisdiction over all civil suits except petty matters (under 40 shillings) which were heard before a single justice of the peace, and cases in which the Crown was plaintiff. The court gave de novo trials in appeals of decisions of the justices of the peace. The court met quarterly in the town of Plymouth. NELSON, DISPUTE AND CONFLICT RESOLUTION, supra note 5, at 22-23.

77. Howland v. Hatch, Common Pleas (June 1725), in 5 Plymouth Court ReCoRds, 16861859, at 191-92 No. 25 (David Thomas Konig ed., 1978) [hereinafter PLYMOUTH COURT RECORDS]. 
oxen," 78 to a sum of money "to Ballance for English Hay," 79 to "time, travel and assistance," 80 or for "Shoes, Drink, Entertainment, and Wares," ${ }^{81}$ to "work done at the furnace in Pembroke and a canoe sold," ${ }^{82}$ to "one freight of Lumber from Rochester to Chilmark, in the Sloop Adventure." ${ }^{83}$ Like trading in commodity money, book account transactions (with pounds, shillings, and pence as units of account) served the purposes of coins or paper money because they eliminated the need for direct exchanges of goods as in barter.

Book accounts also permitted more precise compensation than when goods were directly bartered. Cases from the Plymouth Inferior Court of Common Pleas, for example, demonstrate that book accounts often recorded the balance owed one party or another after an exchange. A case heard in May 1730, for example, was a suit for a book account debt on the grounds that the plaintiff and defendant "Exchanged Mares and in Consideration whereof the then [Plaintiff's] Mare which he Delivered to the [Defendant] was Beter than the mare which the [Plaintiff] Received of the Defendant." 84 A 1722 case similarly derived from balance "due upon Exchange of Oxen." ${ }^{85}$ Book accounts therefore facilitated barter exchanges that otherwise might not have occurred because they enabled precise compensation in exchange.

Book account records of mutual indebtedness were typically settled over the course of many years. The Massachusetts government tried to establish a statute of limitations for book account debts at various times, but its efforts failed. ${ }^{86}$ The success of the book account system derived from the ability of people to enter long courses of dealing, variously borrowing and lending to each other over time. Book accounts were also used for arrangements by which those needing goods or money (when available) would unilaterally take credit from wealthier merchants and traders. When

78. Knowlton v. Donham, Common Pleas (Dec. 1725), in id. at 196 No. 3.

79. Holbroke v. Hyland, Common Pleas (Mar. 1733), in id. at 436 No. 38.

80. Little v. Browne, Common Pleas (Mar. 1718), in id. at 78 No. 19.

81. Foord v. White, Common Pleas (July 1718), in id. at 83 No. 13.

82. Despard v. Little, Common Pleas (July 1718), in id. at 82 No. 1.

83. Cowing v. Clarke, Common Pleas (Dec. 1725), in id. at 196 No. 8.

84. Richmond v. Cavender, Common Pleas (May 1730), in id. at 332 No. 1.

85. Cushing v. James, Common Pleas (June 1722), in id. at 140 No. 3.

86. In 1669 , Massachusetts passed a law setting the statute of limitations for book account debts at three years. Debts by Book (n.d.), GENERAL LAwS 39, 39-40, reprinted in THE COLONIAL LAWS OF MASSACHUSETTS, supra note 44. In 1672, however, when the government was supposed to begin enforcing the law, "[u]pon a general complaint, that the said Law will prove to the real detriment of very many of our inhabitants, and the utter undoing of some if a greater number of years be not allowed to shut up Accompts [accounts]" debtors were given three more years before the law would be enforced. See Book-Debts (1672), SEVERAL LAWS AND ORDERS MADE AT THE GENERAL COURT, May 15, 1672, at 4, reprinted in THE COLONIAL LAWS OF MASSACHUSETTS, supra note 44, at 204. In 1675, however, the deadline was extended two more years, and in 1677, three more years. Finally, in 1679, the law was repealed. See id. at 219, $253,266$. 
farmers, for example, took imported goods on credit, creditors might maintain book accounts, recording repayments of the debts in goods the farmers produced, such as grain, meat, or services. ${ }^{87}$ Debtors entering this type of relationship often found themselves bound to one creditor for long periods of time.

More formal credit instruments such as conditional bonds, ${ }^{88}$ bills obligatory, ${ }^{89}$ and promissory notes were also used as money substitutes. Although there were no checking accounts before the existence of banks, conditional bonds, bills, and promissory notes were colonial analogues. Like checks, bills and promissory notes drew off of accumulated reserves and could be used directly in transactions. For example, a trader with an accumulated reserve of, say, gunpowder could store the gunpowder in a

87. Farmers' repayments of this nature, like taxes paid in farm produce, were termed "country pay."

88. Bonds were written, sealed instruments by which a person agreed to pay a sum of money on a particular date unless a condition-generally, delivery of goods or services-was performed according to specification. For a description of the legal features of bonds, see MANN, supra note 7, at 28-29; and Chafee, supra note 10, at li-liii. See also Beutel, supra note 44 , at 142.43 (discussing the assignability and negotiability of bonds and bills in the colonial period). The issue of bonds has gained prominence in legal historical scholarship because the method by which damages for breach were determined disproved the widely held view among legal historians that colonial law differed from English law because of its lack of equity. According to Roscoe Pound, for example, the Puritan community had "always been a consistent and thorough-going opponent of equity." Roscoe Pound, Puritanism and the Common Law, 45 AM. L. REv. 811, 825 (1911). This conception was challenged by Zechariah Chafee and others who demonstrated that, unlike in England, colonial courts "chancered" bonds with regularity. Chafee, supra note 10, at 1-lii. Chancering bonds meant that the plaintiff was awarded the value of the condition that was to be performed, plus, in some cases (by the judge's discretion), damages suffered by nonperformance plus interest, rather than the full amount of the bond. $l d$. at lii. Although Morton Horwitz concedes that bonds were chancered at times, he argues that bonds were popular because they were a means of avoiding judicial equitable inquiry into the faimess of the exchange. See HORWITZ, supra note 1, at 167-68. In my review of the Plymouth County Court Records from 1720 to 1755, I found that judges "chancered" the bonds in all bond cases. See 5-6 PLYMOUTH COURT RECORDS, supra note 77.

89. Bills obligatory and promissory notes were written promises to perform a condition or to pay an amount of money by a specified date. Unlike book accounts, bills and notes were specific with respect to the form and time of payment. They were made assignable in Massachusetts in 1647 and in Connecticut in 1650. See Beutel, supra note 44, at 141.

Bills obligatory should be differentiated from bills of exchange. In Europe, bills of exchange typically were issued by factorage houses to merchants as a way for them to avoid transporting and exchanging currencies. When a merchant wanted to buy goods abroad, he could pay a factorage house to issue a bill of exchange and use it as payment. The receiver could then take the bills to a local factorage house, which could redeem it from the original factorage house or issue it to someone trading in its country of issue. Larry Neal, The Finance of Business During the Industrial Revolution, in 1 THE ECONOMIC HISTORY OF BRITAIN SINCE 1700, at 151, 157-63 (Roderick Floud \& Donald McCloskey eds., 1994). Bills of exchange were rarely litigated in the New England colonies, possibly because of the lack of major factorage houses and the unfavorable balance of trade. In England, although not in the colonies, promissory notes differed from bills because they were not assignable, meaning that the original issuer of the note (the IOU) was responsible for redeeming it. This tended to make promissory notes a device used within a close community, where holders could monitor the ability of the original debtor to redeem the note. Id. at 162-63. In contrast, in the American colonies, bills obligatory and promissory notes were virtually indistinguishable. 
warehouse and issue a promissory note or bill payable in the reserves. ${ }^{90}$ Similarly, prominent merchants often allowed their customers to issue bills and notes for sums of money based on their customers' credits on the merchants' balance sheets. ${ }^{91}$ When a warehouse operator or merchant kept only a fraction of his customers' balances on reserve, he increased the total money supply, as banks do today. ${ }^{92}$

What distinguishes bonds, bills, and promissory notes from modern checks is that they were frequently assigned and negotiated, and they circulated within a community as a currency.$^{93}$ Their circulation was likely to extend only as far as the reputation of the payor. Their value depended upon the extent to which the holder of the note was able to monitor the debtor to ensure that he or she would pay the debt at the date of liquidation. Thus, the basic money supply was increased by the use of assignable notes, bonds, and bills but, as with book accounts, these devices functioned within the context of relatively small communities.

Colonial law diverged from English law by treating written obligations promising payment in commodities and services similarly to written obligations promising monetary payments. ${ }^{94}$ Indeed, the Massachusetts General Court enacted the Payments statute, which vested power in the parties themselves to determine the form in which such obligations would be repaid. As amended in 1670 , the Act declared that: " $[\mathrm{H}]$ enceforth all Contracts, Agreements, Engagements or Covenants for any specie

90. See BAXTER, supra note 69 , at 28 .

91. Thus, in the colonial period, some prominent merchants performed the lending function of banks by permitting their customers to offer bills and notes based on their balances, through direct loans, and by acting as a clearinghouse for their customers, transferring assets from one account to another based on the bills and notes they issued. See BAXTER, supra note 69, at 29-32, 204-08; Virginia D. HaRrington, THE New York Merchant on the Eve of the REVOLUTION 114-16 (1935).

92. Banks increase $M_{1}$ by lending amounts many multiples greater than the reserves they maintain to satisfy them.

93. They were made assignable in Massachusetts in 1647 and in Connecticut in 1650. See Beutel, supra note 44 , at $141 \& \mathrm{nn} .40-41$. These credit instruments could be used in transactions, and thus can be defined as $M_{1}$ for all but the final holder, who actually had to liquidate the debt. Today, of course, checks are literally negotiable, though infrequently negotiated because of the superiority of government-issued fiat money.

94. See id. at 142-49. According to Beutel, commodity paper and money paper were treated alike throughout the colonies. There was no distinction either as to negotiability or assignability between these two types of paper. This constituted the most important development of colonial law of negotiable instruments, and it is fair to say that the colonial courts did not demand that an instrument to be negotiable must be payable in money.

Id. at 144-45 (citation omitted); see also Chafee, supra note 10, at lxxv-lxxxi ("As.might be expected from the statute, title Payments, judgments as well as contracts were frequently payable in merchandise." (citation omitted)). This custom remained the law into the nineteenth century. See, e.g., Clark v. King, 2 Mass. 471, 471 (1 Tyng 524, 524) (1807); Perkins v. Parker, 1 Mass. 89,89 (1 Will. 117, 117) (1804). 
whatsoever, shall be paid in the same specie ${ }^{95}$ Bargained for; Any Law, Usage or Custome to the contrary notwithstanding." 96

In light of this statute, bills and notes were frequently made payable either in goods or a combination of goods and money, or one party was given the choice to pay in goods or money.$^{97}$ The Plymouth Court Records, for example, include a case on a two-month note for $£ 17.1$ " in Moneys or a Cow that the Plaintiff Should Chose out of Six ... and the Rest to be payed in good Barr Iron"; $;^{9}$ on a bond dated February 20, 1732 for "Sixteen Cord of oake wood"; $; 9$ on a note for " $£ 10$ in money and $£ 6$ in salt"; 100 on a bill dated February 28, 1725 for $£ 13$ in "Cole at the Furnance in Pembroke ... at Twenty Shillings a Load 96 Bush[els] to a Load at the Pitt or 80 at the workes"; ${ }^{101}$ and on an "Instrument in Writeing under ... Hand and Seal" for nineteen tons of "Good Iron Oar at the Bed redy dugg up." 102 Thus, in the face of the limitations imposed by chronic monetary scarcity, colonial traders devised informal and formal contractual mechanisms to advance beyond barter, laying the foundations of a commercial society.

\section{Colonial Judicial Remedies Before Widespread Public Currency Circulation}

In the years preceding widespread circulation of paper money, colonial commercial law adapted to the scarcity of cash. The colonial court dockets were dominated by debt-collection cases based on book accounts, promissory notes, and bonds. William Nelson's empirical study of the Plymouth County Courts found that, in the period from 1725 to $1774,74 \%$ of all cases heard in the Inferior Court were suits to reclaim debts. ${ }^{103}$ Bruce

95. Specie did not refer simply to coinage, but to any good used as a means of payment.

96. Payments (1654), GENERAL LAWS 120, 120-21, reprinted in THE COLONIAL LAwS OF MASSACHUSETTS, supra note 44 (footnote added). The original wording of the Act was similar, but allowed substitution with other goods (with additional damages) under certain circumstances:

[A]ll Contracts and Engagements for Money, Com, Chattel or Fish, shall be satisfied in

kinde according to Covenant, or in default of the very kinde contracted for, in one of the said kindes; Provided that in such cases where payment in kinde is not made according to Covenant, all just damages shall be satisfied (together with the Debt) for not paying in kinde according to bargain; And in no case shall any Creditor be forced to take any other Commodities for satisfaction of his debt ....

Id. at 120, 120-21.

97. Beutel, supra note 44, at 142-46; Chafee, supra note 10, at lxxiv-lxxvi.

98. Weston v. Chipman, Common Pleas (Mar. 1736), in 5 Plymouth Court ReCORds, supra note 77 , at 566 No. 23.

99. Josselyn v. Palmer, Common Pleas (Mar. 1734), in id. at 480 No. 2.

100. Mallus v. Kanney, Common Pleas (Sept. 1729), in id. at 293 No. 25.

101. Little v. Bushup, Common Pleas (Mar. 1730), in id. at 320 No. 77.

102. Little v. Jackson, Common Pleas (Mar. 1736), in id. at 579 No. 125.

103. The Inferior Court heard all civil cases except those requesting damages under forty shillings, which were decided by Justices of the Peace. See NeLSON, AMERICANIZATION, supra note 5, at 15-16. Deborah Rosen argues that suits for nonpayment of moneys owed were "the 
Mann found that, in 1700, $82.9 \%$ of debt cases in the Hartford County Court were book account cases; the remainder were promissory note and bond cases. ${ }^{104}$

The colonial legal system also responded to prevailing economic conditions with flexibility regarding judicial remedies. In part because of the scarcity of coins, specific performance and in-kind compensation were the predominant remedies for breach. Massachusetts courts were guided by the Payments statute, described above, meaning that judges and juries awarded the "same specie Bargained for; Any Law, Usage or Custome to the contrary notwithstanding." ${ }^{105}$ Where specific performance was impossible, however, courts required compensation to be paid in goods, which directly reflected the nature of the exchanges taking place-those of goods for other goods, rather than cash-based transactions. ${ }^{106}$ Legal scholars such as Morton Horwitz who have overlooked the conditions of monetary scarcity plaguing the colonial economy, have characterized specific performance and in-kind damages as evidence of a reluctance among colonists to conceptualize the world in monetary terms. ${ }^{107}$ Closer examination of the sources reveals that colonists did in fact conceptualize

quintessential legal injury" of the eighteenth century. See Rosen, Courts and Commerce, supra note 7 , at 140 .

104. See MANN, supra note 7, at 171 tbl.1.

105. See Payments (1670), General Laws 121, 121, reprinted in ThE Colonial Laws of MASSACHUSETTS, supra note 44 , at 120-21.

106. For a few of the hundreds of examples of nonmonetary compensation, see the following remedies provided by different Massachusetts courts (note that money payments are offered as an alternative): A 1724 suit in the Plymouth County Court resulted from an agreement to exchange a greyhound for a "merchantable pair of cartwheels of five foot high with good Iron Hoops." Tumer v. Darling, Common Pleas (Sept. 1724), in 5 Plymouth COURT ReCORDs, supra note 77, at 175 No. 28. Turner argued that he delivered the greyhound; the court awarded him "the cartwheels or $£ 3$, and $£ 3.5$ s. $6 \mathrm{~d}$ costs." Id. In a 1733 case on a promissory note for $£ 37.16 \mathrm{~s} .1 \mathrm{~d}$. to be paid "Either In Grain At the Marquit price or In bills of Good publick Credit," the jury awarded the plaintiff $£ 37.16 \mathrm{~s}$.Id. "in grain or in bills of credit." Shepherd v. Clerke, Common Pleas (Dec. 1733), in id. at 470 No. 32; see also Thomas v. Williams, Common Pleas (Mar. 1737), in 6 id. at 30 No. 35 ( $\$ 100$, " $2 / 3$ to be paid in 'Money' and 1/3 in goods"); Lamb v. Thomas (August 19, 1690), in COLONIAL JUSTICE IN WESTERN MASSACHUSETTS (1639-1702): THE PYNCHON COURT RECORD 325, 326 No. 211 (Joseph H. Smith, ed. 1961) [hereinafter PYNCHON RECORD] ("a barrel of Tar or .13 s[hillings]"); King v. Mooreley (Feb. 18, 1690), in id. at 326, 326 No. 211 (".5s now in come which he says is ready: and $.4 \mathrm{~s}$ in worke betweene this and Midsummer next"); Pettey v. Cooper (Feb. 18, 1688) in id. at 321, 321 No. 206 ("one Pound, 12s $2 \mathrm{~d}$ due in Porke" ); Atherton v. Lockwood (Oct. 27, 1674), in RECORDS OF THE SUFFOLK COUNTY COURT 1671-1680: PART I, supra note 10, at 512, 512-13 ("a good Mercators draft or Fifty one Shillings in mony"); Ball v. Rigbee (Oct. 27, 1674), in id. at 500,500 ("thirty five pounds to bee paide in mony \& green hides"). The Plymouth County Court Records include a 1686 case in which weekly child support payments were to be made "in money or corn." See Case of Mary. Sutton, Common Pleas (Sept. 1686), in I PLYMOUTH COURT RECORDS, supra note 77, at 190. Judicial remedies also adhered to the type of currency stated in the bargain. Thus when William Fling sued William Dyre for failing to pay him $£ 3$ in "Lawfull Money of our Island of Jamaica" due for "Two Barrels of Makrel" sold to the defendant in Kingston, the jury awarded Fling f2.17s.6d. "in Jamaica money." Fling v. Dyre, Common Pleas (May 1731), in 5 id. at 381 No. 22.

107. See HoRWITZ, supra note 1 , at 162-63. 
goods in monetary terms, but monetary scarcity made barter and, thus, inkind damages awards a necessity.

The Payments rule and the prevalence of in-kind compensation did not prevent litigation over the form of remedy for breach. Many credit agreements left the choice of the form of repayment to one of the parties, possibly because of the difficulty of knowing in advance what money or commodities would be available to the promisor at the time of performance. The lack of specificity, however, was an obvious source of subsequent litigation. Similarly, in early New England, the scarcity of money and thin market conditions led judges at times to require creditors to accept the goods that debtors were able to pay, although those goods were not stipulated in the agreement and possibly not desired by the creditor. Judges, at times, therefore acted as barter agents. In Pope v. Stebbings, ${ }^{108}$ for example, Pope argued that Stebbings owed him nine shillings and six pence, to be paid in wheat, and Stebbings, supported by testimony of two witnesses, argued that his attempt to deliver 0.2 bushels of Indian corn and 1.5 bushels of rye was full payment of the debt. ${ }^{109}$ The judge decided that "Pope should have taken said pay and is now to take up therewith, and pay Costs of Court." 110 This case, and others like it, reveal a feature of the way in which barter conditions affected commercial litigation: Remedies had adapted to the scarcity of cash and uncertainty about whether and when an individual would be in possession of specific goods. ${ }^{111}$ 173.

108. Pope v. Stebbings (Sept. 23, 1680), in PYNCHON RECORD, supra note 106, at 294 No.

109. Id.

110. Id. Judges, however, did not always require individuals to accept any goods in the possession of the debtor. On the same day, Pope brought another case in which he argued that Rust promised to pay him five shillings for work "making tuggs ... of cedar to serve instead of Cork for a net." Id. (citing Pope v. Rust (Sept. 23, 1680)). Rust tried to repay him with other various goods that Pope rejected. This time the judge held for Pope, deciding that "only the small Bass fish" that Rust gave to Pope should count against the award. Id.

111. Variation in market price or in value of currency led some to take advantage of option contracts. For example, in French v. Tyng, a 1673 Suffolk County Court case, Tyng had promised to deliver logwood, breached the promise (selling the logwood at a price greater than the contract price) and had offered to give the contract amount back in money because "hee Could make more of his Logwood, then the Sume expressed" although he later changed his mind, deciding to repay in the wood. The court decided for the plaintiffs, holding that Tyng owed money. French v. Tyng (July 29, 1673), in RECORDS OF THE SUFFOLK COUNTY COURT 1671-1680: PART I, supra note 10, at 285-87. In Batt v. Wells, however, the Suffolk County Court held that money would serve as a default when no form of compensation was specified. Batt, the creditor, won an award for over $£ 8$ in money and Wells appealed. The question on appeal was whether the $£ 8$, for which no agreement was made, should be paid in money or goods or labor (Batt had paid Wells in goods). The Court of Assistants confirmed the former judgment granting money to Batt and granted Batt additional costs (no reasoning is given). Batt v. Wells (July 27, 1675), in 30 PUBLICATIONS OF THE COLONIAL SOCIETY OF MASSACHUSETTS, RECORDS OF THE SUFFOLK COUNTY COURT 16711680: PART II, at 614-17 (1933); cf. Skirvan v. Willis, 4 H. \& McH. 483 (Md. 1728) (holding that a holder of a judgment in tobacco was not allowed to collect its money value). 


\section{Assessing the Costs of Monetary Scarcity}

\section{The Limitations of Money Substitutes}

Aggregate transaction costs are likely to be higher in a society reliant on commodity money and endogenous private currencies such as assignable debt obligations than in a society reliant on a stable, widely available, and universally accepted currency, such as gold and silver coins or fiat money. Colonial commodity monies served the functions of cash, but they imposed costs that could be alleviated through use of a stable paper money. First, commodity monies had to be constantly regulated for value. Second, their value fluctuated with supply and demand conditions, often determined in international markets. Third, those who accepted commodity money as payment had to bear the costs of resale, which would be determined by the market conditions for the good. ${ }^{12}$ Each of these costs also applied to governments' efforts to tax in commodity money.

The costs of using book accounts were of a different nature. First, although the book account system represented a substantial advance over pure barter, it reduced, but did not eliminate, the need for a coincidence of wants. To obtain a book account debt, a person had to offer to repay the debt in terms acceptable to the creditor. The scarcity of coins meant that in cases where two parties did not believe that the coincidence of wants would occur sometime in the future, the transaction would fail. Second, giving goods on credit could be highly risky with strangers or in an environment with high levels of migration. Collecting debts owed to people dispersed throughout a colony was extremely costly and ineffective. Book accounts were successful instead in environments in which individuals could develop reputations, often where individuals had longstanding relationships. Thus, reliance on book accounts confined commercial transactions to relatively insular communities where information about borrowers' characters, economic successes, and uses of loans were readily available. ${ }^{113}$ Although

112. Gold and silver worked well as commodity monies because these problems were minimized. Their supply was relatively stable and thus they did not suffer extreme fluctuations in value during most periods. They were also easy to resell in the marketplace.

113. Within the recent economic literature, credit relationships in developing economies are commonly analyzed in terms of information asymmetries. Lenders can more successfully prevent loan default when they can separate high-risk from low-risk borrowers. To do so requires information about the character and competence of the borrower and information about use of the loan after they enter loan agreements. According to this literature, there are several ways in which the problem of asymmetric information can be resolved. One is through information collection or monitoring: Monitoring involves both initial screening to exclude debtors with bad reputations and credit records, and oversight of the use of the loan. When a lender does not have reliable information about the borrower, however, he or she must rely on other devices. First, borrowers and lenders can generate information through repeated interaction, such as a borrower repeatedly borrowing from the same lender to develop a reputation. Second, lenders may offer only a shortterm loan. Third, lenders can require that borrowers securitize their loans, either with individual 
current legal scholarship characterizes the trust required in the book account system as an extension of colonists' community-oriented consciousness, the causality likely ran the other way. Relations of trust and a communityoriented consciousness are perhaps more convincingly viewed as a response to currency scarcity and as representing efforts to overcome it in order to promote exchange.

Like book accounts, private assignable debt obligations were also attended by costs related to the need for security that the debt would be repaid. Regardless of denomination, the value of a promissory note is equal to the reliability of the promise. Bills of exchange were successful throughout Europe and among colonial merchants because they were issued by prestigious European factorage houses whose reputation over a wide geographic range kept the value of the bills high. ${ }^{114}$ There were no exactly equivalent institutions in the New England colonies, although notes were often drawn on credit balances held by prominent merchants who were known throughout a wide community. Notes issued by less prominent people, however, were more uncertain and, like book accounts, were likely to serve as debt only within smaller communities. Debtors were typically required to find reliable cosigners (sureties) to secure loans. In the alternative, a note holder might attempt to monitor the economic activities of the note issuer directly, which was more feasible when the note issuer and note holder lived within the same community. ${ }^{115}$ Thus, the volume of notes and bills in circulation was limited by the costs of finding cosigners and the geographic reach of individuals' reputations.

The colonial economy, thus, must be characterized as one of thin, dispersed markets. As described in Section I.A, the extent of specialization and comparative advantage in a society is largely determined by the aggregate costs of transacting and by the extent of the market. Although developed markets existed in colonial New England, principally in coastal towns, colonists commonly engaged in subsistence agricultural production with little market involvement. According to Richard Bushman, in early

collateral, or by finding someone with assets to cosign the loan. See, e.g., Ernst Baltensperger, Credit, in The New Palgrave: MONEY, supra note 33, at 100; Timothy W. Guinnane, Cooperatives as Information Machines: German Agricultural Credit Cooperatives, 1883-1914, 61 J. ECON. HIST. (forthcoming June 2001); Joseph E. Stiglitz, Peer Monitoring and Credit Markets, 4 WORLD BANK ECON. REV. 351, 352 (1990); see also DEBRAJ RAY, DEVELOPMENT ECONOMICS 559-61 (1998) (describing a case study of methods used by moneylenders in villages surrounding Chambar, Pakistan, to ensure high rates of loan repayment).

Book account creditors often relied on information efficiencies made available by a context of relatively insular communities. They typically required no collateral or cosigning, and allowed debts to remain outstanding for many years.

114. See Charles P. Kindleberger, a financial history of Western Europe 41-43 (2d ed. 1993); Neal, supra note 89, at 157-63.

115. For an empirical analysis of loan terms and the geographic proximity of creditor to debtor in small German towns, see Guinnane, supra note 113. 
Connecticut, "[a] family had to buy a musket, a pot, and salt," ${ }^{116}$ producing all other necessities themselves. Where markets are relatively dispersed or nonintegrated, there are high costs to the circulation of market information and, as a consequence, there is likely to be substantial price differentiation. ${ }^{17}$

The colonial economy was limited in several other ways because of high transaction costs and thin markets. Thin, nonintegrated markets increase the potential for market power and, thus, opportunities for price discrimination. Barter increases the costs of arbitrage. In thin markets, a seller is better able to obtain what a specific buyer is willing to pay, rather than value based on general societal demand for the good. As a consequence, a seller under barter is in a far better position to pricediscriminate: to offer goods at different prices to different individuals. Captain John Blackwell, a Massachusetts pamphlet writer and promoter of private banks, made this point in 1687, three years before public-currency issuance: "[T]he experimented inconveniencies of Common Barter by Commodities: In which way, unlesse both the parties dealing had like occasion reciprocally of each other's, the lesse necessitous over-reached the greater, by imposing ye Price of both: to his owne Advantage, and the others detriment, which was not equall." 118

Price convergence for a good occurs when its value is established by general demand and not differentiated according to separate individual preferences. Price discrimination is not always socially harmful: Charging prices based on individual preferences can allow sellers to profit from those

116. BUSHMAN, supra note 9 , at 26. People living in towns, of course, were more likely to purchase goods produced by others. Thus, there is an important influence of the movement from barter to cash on urbanization, a subject beyond the scope of this Article.

117. Obviously, in a competitive market, the prices of homogenous goods will converge toward uniformity. In a study of farm labor markets in Massachusetts from 1750 to 1855 , Winifred Rothenberg shows an increase in compensation with the development of markets in proportion to the precise value of the skill performed. Rothenberg analyzed 3285 entries of taskspecific per diem wage observations for day labor taken from ninety account books from sixtyfive towns in New England (fifty-two in Massachusetts). She categorized tasks into two groups: higher-paid and lower-paid. Over the course of the period from 1750 to 1855 , she found a substantial increase in differentiation between higher- and lower-paid tasks, suggesting that, with the development of markets, laborers began to be paid more precisely according to the value of the skill that they performed. According to Rothenberg,

This widening stratification ... is itself evidence of an increasingly efficient market in which wages respond, with greater sensitivity over time, to seasonal urgencies in the demand for specialized labor, to tasks with differential skill components, to the impact on the elasticity of labor supply of job opportunities off the farm, and to shifts in demand for crop-specific tasks....

Winifred B. Rothenberg, The Emergence of Farm Labor Markets and the Transformation of the Rural Economy: Massachusetts, 1750-1855, 48 J. ECON. HisT. 537, 540-41 (1988).

118. [JOHN BLACKWELL], A DISCOURSE IN EXPLANATION OF THE BANK OF CREDIT (n.p. 1687) [hereinafter DISCOURSE], reprinted in 1 COLONIAL CURRENCY REPRINTS, supra note 20, at 120,122 . Andrew McFarland Davis, who compiled the Colonial Currency Reprints, attributes authorship of this pamphlet to Blackwell on the basis of the handwriting. 
who can pay and charge lower prices to the poor. But it can also result in the reverse: lower prices to buyers possessing information and higher prices to the less-informed. Price discrimination is made possible not entirely by a lack of currency, but by a lack of competitive markets in which prices are set according to general demand. ${ }^{119}$ The problems of nonintegrated markets and market power in early modern economies may have been the practical impetus for community-wide restraints on profiteering such as the enforcement of "just prices" and prohibitions on usurious practices, commonly enforced in Massachusetts Bay preceding currency issuance. The development of markets eliminates the need to reduce information deficits by government price-setting.

Although these various impediments of thin markets might simply be viewed as a form of increased costs, many have claimed that they are sufficient to create a separate "barter culture," qualitatively different from a cash-market culture because of a reduced level of interest in profitseeking activity. ${ }^{120}$ Early New England residents claimed that conditions of monetary scarcity had debilitating effects personally as well as on the economy. According to one early Massachusetts resident, a poor market

119. For a discussion of enforcement of just prices in colonial New England see, for example, BAILYN, supra note 72, at 41 . The connection between price discrimination in barter and the need for government regulation of prices was recognized by at least one commentator in colonial Massachusetts. In Blackwell's 1687 pamphlet, quoted above, he argued that governmentdetermined prices would be a solution to the problem:

The Inconveniences of the way of Barter might have been much obviated, By a frequent setting a just $\&$ equall value of the Price of all commodities, by publique authority, according as the plenty or scarceity of them should require, and the market had ruled: But, there being no such common standard, Money hath obteyned $\&$ been admitted as the best ballance of Trade, both by wise $\&$ un-wise. . . [but] ' $t$ is now so hard to come by, for the carrying on of trade, to answer the vastness of men's attempts \& aymes of increase in Merchandize, as that it's suspected to be insufficient in this age of the world ....

DISCOURSE, supra note 118 , reprinted in 1 COLONIAL CURRENCY REPRINTS, supra note 20, at 122-23.

120. There is substantial scholarly disagreement on the "mentality" of barter economies. Rothenberg describes signs of advancements from barter, such as book accounts and multiple credit transactions, as "testify[ing] like a thumb in the dike" to the presence of the market and "to its 'latent threat'... to effect transforming change." Rothenberg, supra note 117, at 539. Henretta, in contrast, argues,

[T] he predominance of subsistence or semi-subsistence productive units among the yeoman farming families of the northern colonies was not only the result of geographic or economic factors-the ready access to a reliable, expanding market. These men and women were enmeshed also in a web of social relationships and cultural expectations that inhibited the free play of market forces.

James A. HenretTa, Families and Farms: Mentalité in Preindustrial America, in THE ORIGINS OF AMERICAN CAPITALISM: COLLECTED ESSAYS 71, 97-98 (1991). See generally Paul Lewis, In Buying We Trust, The Foundation of U.S. Consumerism Was Laid in the 18th Century, N.Y. TIMES, May 30, 1998, at B7 (describing a recent trend in historical scholarship that characterizes colonists as embracing consumerism). 
"tends to enervate and abate the Vigour and Zeal of the Farmer, renders him indolent, takes off the Edge of Industry." 121

Some believed that increased profit-making incentives created by currency circulation would change the cultural norms of the poor. John Blackwell, who attempted to institute a private currency in 1687, claimed that currency would have a socially transformative effect, arguing that circulation of money "helps to civillize the Ruder Sort of people, \& incourages others to follow their example in industry \& civillity." 122 This Article does not attempt to resolve the barter culture debate. It is evident, however, that colonial economic conditions did not extinguish entrepreneurial energies. Despite monetary scarcity, colonists developed mechanisms that enabled transaction and commercial organization far beyond that possible under pure barter.

\section{Economics Scholarship on Colonial Economic Growth}

Did quasi-barter conditions affect economic growth levels? The response is important to a theory of the relation of law to economic advance. As described above, the central empirical evidence supporting the modernization theory consists of the volume of debt cases in colonial courts over the first half of the eighteenth century: Rising levels of debt litigation are characterized as a signal of economic expansion. Litigation data themselves, of course, do not directly indicate economic progress. The link between increases in litigation and economic growth, instead, is merely assumed. Thus, Mann describes greater use of credit instruments as better suited to the "expanding economy of eighteenth-century Connecticut." 123 Dayton emphasizes the eighteenth-century "boom" and characterizes the period from 1710 to 1750 as "the most expansive decades of New England's preindustrial history." ${ }^{124}$ Rosen, similarly, bases her conclusions on the assumption of "substantial commercial expansion." 125

Closer attention to economics scholarship, however, raises considerable doubt about the characterization of this period as one of substantial economic growth. In a review of current economic literature, James A. Henretta concludes that the growth rate in per capita income in the New

121. BUSHMAN, supra note 9, at 26-27 (quoting JARED ELIOT, ESSAYS UPON FIELD HUSBANDRY IN NEW ENGLAND AND OTHER PAPERS, 1748-1762, at 187 (Harry J. Carman \& Rexford G. Tugwell eds., 1934)).

122. DISCOURSE, supra note 118 , reprinted in 1 COLONIAL CURRENCY REPRINTS, supra note 20 , at 130 .

123. MANN, supra note 7, at 37.

124. DAYTON, WOMEN BEFORE THE BAR, supra note 7, at 90, 94.

125. Rosen, Courts and Commerce, supra note 7 , at 142. 
England colonies averaged no more than $0.2 \%$ to $0.5 \%$ a year. ${ }^{126}$ Alice $\mathrm{H}$. Jones describes the relative stagnancy of New England during the eighteenth century as opposed to the seventeenth century. ${ }^{127}$ More particularly, McCusker and Menard measure per capita consumption, showing that average annual per capita exports from Great Britain to the colonies set in constant terms hardly changed over the period from 1699 to 1774. ${ }^{128}$ Empirical data from more local studies further confirm a low growth rate during the first half of the eighteenth century in colonial New England. John Waters finds that in Guilford, Connecticut, the mean ratable wealth per resident male taxpayer declined from 1716 to $1749 .{ }^{129}$ Terry Anderson examines data on wealth and productivity in Hampshire County, Massachusetts, and concludes that "the one bleak period in [America's] growth history was the first eighty years of the eighteenth century.... [E]stimates of productivity in New England agriculture suggest that the growth rate may well have been negative." 130

While the statistics seem generally inconsistent with the assumption that the period was one of modernization and economic expansion, per capita figures must be considered in light of high rates of population growth

126. JAMES A. HENRETTA, Wealth and Social Structure, in THE ORIGINS OF AMERICAN CAPITALISM: COLLECTED ESSAYS, supra note 120 , at 148, 167 (finding that, although there is variation between economists' studies, all current scholarship places per capita growth rates in the New England colonies within the range of $0.2 \%$ to $0.5 \%$ ). Based on their evaluation of Massachusetts and Connecticut probate records, for example, Gloria L. Main and Jackson T. Main argue that total estate value in pounds constant per free white male had an average annual growth rate of between $0.35 \%$ and $0.5 \%$ in the period from 1650 to 1774 . Gloria L. Main \& Jackson T. Main, Economic Growth and the Standard of Living in Southern New England, 1640-1774, $48 \mathrm{~J}$. ECON. HIST. 27, 35 (1988) (using two different indices to find results of $0.35 \%$ and $0.5 \%$ ). Others have calculated similar growth rates for the American colonies as a whole. JAMES F. SHEPHERD \& Gary M. WAlton, ShipPing, Maritime Trade, and THE ECONOMIC DevelopMENT of COLONIAL NORTH AMERICA 30 (1972) (finding a rate of "well under 1 per cent"); GARY M. WALTON \& HUGH ROCKOFF, HISTORY OF THE AMERICAN ECONOMY 98 (6th ed. 1990) (calculating a rate of slightly below $0.5 \%$ ); Ralph L. Andreano, Introduction to NEW VIEWS ON AMERICAN ECONOMiC DEVElopment: A SElective ANTHOlOgy Of ReCENT WORK 41, 50-51 (Ralph L. Andreano ed., 1965) (finding a rate of 0 to $0.5 \%$ ). Alice Hanson Jones argues that the colonies' per capita nonhuman wealth increased $0.3 \%$ per year during the period from 1650 to $1725,0.4 \%$ during the period from 1725 to 1750 , and $0.5 \%$ during the period from 1750 to 1774 . alice Hanson Jones, Wealth of a Nation To Be: THE American Colonies on the Eve of THE REVOLUTION 305 (1980).

127. See JONES, supra note 126 , at 304.

128. They found that average annual per capita exports in constant terms were: $\mathfrak{f} 0.9,1699$ $1704 ; £ 0.8,1718-1723 ; £ 1.0,1747-1751$; and $f 1.2,1767-1774$ (average annual per capita exports to New England were $£ 0.9,1699-1704 ; £ 0.8,1718-1723 ; £ 0.8,1747-1751$, and $£ 1.0,1767-1774$ ). JOHN J. MCCUSKER \& RUSSELl R. MENARD, THE ECONOMY OF BRITISH AMERICA, 1607-1789, at 280 tbl.13.1 (1985).

129. Waters found that the mean ratable wealth per resident male taxpayer was $\mathfrak{f 6 6 . 9}$ in 1716 , $\mathfrak{f} 61.3$ in $1732, \mathfrak{f 7 2 . 4}$ in 1740 , and $\mathfrak{f 6 2 . 7}$ in 1749. John J. Waters, Patrimony, Succession, and Social Stability: Guilford, Connecticut in the Eighteenth Century, 10 PERSP. AM. HIST. 131, 159 (1976).

130. See Terry L. Anderson, Economic Growth in Colonial New England: "Statistical Renaissance," 39 J. ECON. HIST. 243, 256 (1979); see also HENRETTA, supra note 126, at 166-68 \& tbl.1 (referring to the Anderson and Waters studies). 
during the colonial period. ${ }^{131}$ McCusker and Menard estimate that New England's population grew at an average of $2.4 \%$ per year over the period from 1660 to $1780 .{ }^{132}$ Thus, assuming per capita growth rates of $0.2 \%$ and $0.5 \%$, respectively, total (not per capita) economic growth averaged between $3.08 \%$ and $4.1 \%$ per year. ${ }^{133}$ These average total economic growth figures are not inconsiderable for a developing economy. ${ }^{134}$

Economic scholarship suggests, however, that most colonial economic growth did not occur during the period from 1700 to 1750 , the period of alleged legal modernization. As mentioned, the figures presented above are averages for the entire colonial period. McCusker and Menard argue that most American colonial economic growth occurred during two "spurts": the first occurring in the decades after initial settlement in each region, and the second occurring from the 1740 s until the Revolution. ${ }^{135}$ The period of alleged legal formalization occurred between these spurts, a time characterized by McCusker and Menard as an "era of stagnation." 136 Jackson Turner Main's study of colonial Connecticut varies slightly: Main emphasizes that there were several growth spurts and recessions, but similarly concludes that, "the level of wealth on the eve of the Revolution differed very little from that in $1700 . " 137$ Shepherd and Walton, who study the colonial maritime industry, conclude that "the weight of opinion and evidence places average annual growth rates in colonial America at relatively low levels," ${ }^{138}$ with the New England colonies at the bottom. ${ }^{139}$

131. Population growth distorts the correlation between per capita wealth and economic expansion because newly added members of a society will generally have lower than average incomes (for example, immigrants and newborns). When population growth rates are high, substantial economic growth can occur despite a low increase in per capita growth levels. See generally HENRETTA, supra note 126, at 169-76 (discussing the problem of assessing increases in wealth in light of population growth in the northern and southern colonies). Although it is beyond the scope of this Article to discuss the issue in detail, population growth rates can also affect economic growth in a developing economy with a sparse population by allowing the release of labor from subsistence farming. See also ESTER BOSERUP, THE CONDITIONS OF AGRICULTURAL Growth: THE ECONOMICS OF AGRICULTURAl ChaNGE UNDER POPUlation PRESSURE 63-64 (1965) (arguing that rapid population growth stimulated the eighteenth-century European agricultural revolution).

132. MCCUSKER \& MENARD, supra note 128 , at 217.

133. Total economic growth is derived from per capita growth and population growth statistics by the following formula: $G_{\mathrm{pc}}=\left(\left(G_{\mathrm{y}}+1\right) /\left(G_{\mathrm{p}}+1\right)\right)-1$, where $G_{\mathrm{pc}}$ is economic growth per capita, $G_{\mathrm{y}}$ is total economic growth, and $G_{\mathrm{p}}$ is population growth. I am grateful to Timothy Guinnane for clarifying these relationships.

134. The economic historian Nick Crafts, for example, found lower growth rates for England during the eighteenth and early nineteenth centuries. Nick Crafts, The Industrial Revolution, in 1 THE ECONOMIC HISTORY OF BRITAIN SINCE 1700, supra note 89, at 44, 47 tbl.3.3 (finding growth rates of $0.6 \%$ to $1.9 \%$ during the period from 1700 to 1831 ); see also Robert Allen, Agriculture During the Industrial Revolution, in id. at 96, 100-03 \& fig.5.1 (reviewing literature on growth rates during England's agricultural and industrial revolutions).

135. MCCUSKER \& MENARD, supra note 128 , at 60.

136. Id.

137. Jackson TURner Main, SOCIETy and ECONOMy in Colonial Connecticut 115 (1985)

138. SHEPHERD \& WALTON, supra note 126 , at 30. 
The issuance of paper money created a potential for greater market development, specialization, and economic growth. Government regulation of the money supply, however, led to a new dependence on currency policies for economic stability. As is shown below, currency scarcity and currency gluts throughout the first half of the eighteenth century required colonists to revert to money substitutes and even, at times, to barter. During those periods, colonists revisited the problems they had experienced throughout the seventeenth and early eighteenth centuries, although with more at stake.

\section{PUBlic PAPER MONEy ISSUANCE AND ITS EFFECT ON LITIGATION PATTERNS}

The notion that a government-issued fiat currency, with legal tender status, could successfully satisfy the need for a medium of exchange as well as finance government operations was entirely foreign to the early colonial mindset. Until 1690, no European or colonial government had issued such a currency. ${ }^{140}$ The decision by the Massachusetts government to issue paper bills of credit in 1690, and the further decision to vest the bills with legal tender status in $1712^{141}$ therefore, perhaps unknowingly, initiated a widespread financial revolution. The expenses of the wars against France, for example, drove England to found the Bank of England and to expand its government debt issues in $1694 .{ }^{142}$ In subsequent years, without protest from England, other colonies quickly adopted the Massachusetts system: South Carolina in 1703; Connecticut, New Hampshire, New Jersey, and New York in 1709; Rhode Island in 1710; and North Carolina in 1712.43 These paper currencies fundamentally transformed the nature of economic exchange and debt litigation in Massachusetts and other colonies.

One cause of the transformation was the colonists' voluntary use of the new colonial government paper money as a medium of exchange. The existence of a more widely available currency created the potential for a move from reliance on routine borrowing to greater use of cash exchanges and thus engendered further market development, specialization, and capital accumulation. Government currency issuance and circulation, however, led to a second, "involuntary," transformation of economic and legal relations:

139. JONES, supra note 126 , at 308 ("The South was outstandingly the richest region and New England the poorest, in aggregate wealth, when the value of slaves is included.").

140. See EdWIN J. Perkins, THe ECONOMY OF COlONIAL AMERICA 168 (2d ed. 1988).

141. See infra text accompanying note 173.

142. See KINDLEBERGER, supra note 114, at 55, 77; NETTELS, supra note 44, at 168-69. Unlike the bills of credit issued in the colonies, however, Bank of England bills were never declared legal tender for the payment of private debts. See PERKINS, supra note 140, at 168.

143. See NETTELS, supra note 44, at 253. 
Reliance on paper money led to a new dependency on government policies for economic stability.

The ability to control currency policy gave the colonial governmentsand the English government, through its management of colonial governments' policies-unprecedented power over economic conditions and the stability of contractual promises. ${ }^{144}$ As is shown below, throughout the first half of the eighteenth century, the currency policies adopted in Massachusetts were the outcome of charged conflicts between the Massachusetts House of Representatives and the English government, and were highly unstable. There were periods of currency scarcity (currency appreciation/price deflation) and currency gluts (currency depreciation/price inflation), each of which had a direct effect on the value of outstanding contractual promises and instigated litigation crises.

This Part examines the early history of Massachusetts's paper money policies to explain the relationship between currency policy and legal development. Section II.A describes contemporary views about the need for greater currency. Section II.B explains the initial shift in colonial currency policy and its effects on the supply of gold and silver. Section II.C describes the effect of government control over the money supply on contractual relations. Section II.C also addresses the relationship between changes in currency valuation and litigation. Following this analysis, the next Part explains the historical development of Massachusetts's paper money policies, with particular focus on the relationships between currency crisis and litigation during three periods of currency volatility in the 1720 s and 1730s.

\section{A. The Demand for Greater Currency}

Throughout the late seventeenth and early eighteenth centuries, many colonial citizens advocated increasing the money supply through fiat (nonmetallic) money in order to stimulate economic exchange, increase credit availability, lower reliance on borrowing, ${ }^{145}$ and reduce the volume of litigation. Colonists actively debated, however, whether private or public institutions would be better able to supply a sound medium of exchange. As described earlier, the principal governmental means of expanding the

144. Although beyond the scope of this Article, these new powers and the conflicts they engendered between colonial and Royal governments had an important role in the escalation of tensions that led to the Revolution. See ERNST, supra note 45, passim.

145. More precisely, many colonists believed that a cash-based economy would change the nature of credit and borrowing: Borrowing would no longer be necessary for many daily transactions, such as purchasing low-cost goods, but different forms of borrowing would increase. The increased profit-making ability of more stable markets combined with the existence of accumulated cash reserves (particularly with a banking system) was expected to lead to an environment with increased credit. See infra text accompanying notes 196-197. 
money supply known in the seventeenth century was to overvalue coins for the purpose of drawing them in from abroad or from other colonies. ${ }^{146}$ Toward the end of the seventeenth century, private institutions were viewed as possibly a better means of resolving the problem of currency scarcity. In 1686 , for example, a group of merchants in Boston attempted to establish a bank that would issue bills for use as a medium of exchange secured by personal property and land. Captain John Blackwell, one of the principal promoters of the bank, argued that the bank was necessary "for the present supply of the great scarceity of money here, for carrying on the Ordinary commerce amongst Traders; who, unlesse speedily releived by this medium, will, in all probabillity, be suddainly exposed to breaking and utter Ruine." ${ }^{47}$ The bank would have issued bills equal to half the value of an individual's collateral. ${ }^{148}$ The projectors hoped that with the issuance of private currencies, "[o]ur owne Native Commodities will thus become improved to a sufficiencie for our owne use (at least) \& thereby afford a comfortable subsistence to many ingenious and industrious persons amongst us." 149 This group carried the project through to the point of printing bills, but abandoned it. Although the reasons for the bank's failure are unknown, ${ }^{150}$ the most plausible is a mercantilist explanation: In 1687, Governor Andros spoke against the proposal as unfavorable to England's trade, and the bank closed soon after a pamphlet was published in 1688 reiterating Andros's views. ${ }^{151}$

Because of the inability of the 1686 bank or other private institutions to gain popular confidence sufficient to supplement the currency supply, currency advocates pressured the Massachusetts government to begin printing paper money. Cotton Mather, a principal advocate of colonial paper money, argued that only bills printed by the colonial government

146. See supra notes $49-55$ and accompanying text.

147. DisCOURSE, supra note 118 , reprinted in 1 COLONIAL CURRENCY REPRINTS, supra note 20, at 124. According to Blackwell, "[Money] is now so hard to come by, for the carrying on of trade, to answer the vastness of men's attempts \& aymes of increase in Merchandize, as that it's suspected to be insufficient in this age of the world: And that hath put divers persons $\&$ countreys upon contrivances, how to supply that deficiencie, by other Mediums." Id. at 123.

148. Blackwell argued that bank notes would be secure because the bank would "be managed in Partnership, by private hands, persons of knowne integrity, prudence and estates: all which will become thereby lyable to answer the injury, damage or Losse to any, by their undertaking." Id. at 124.

149. Id. at 144 .

150. See 1 andrew McFarland Davis, Currency and Banking in the Province of THE MASSACHUSETTS-BAY 7 (1901).

151. See A Supplement or ApPendix to the Treatise Entituled, A Model for ERECTING A BANK OF CREDIT, \&C, OR, AN ACCOUNT OF SOME OF THE MANY PREJUDICES THAT WILl INEVITABLY ENSUE, AS WELl to HIS MAJESTY AS to HIS SUBJECTS by ENHANSING THE VALUe of SPANish COYNS \&C. ABOve His Majesties (London, Thomas Cockeril 1688), reprinted in 1 COLONIAL CURRENCY REPRINTS, supra note 20, at 181; Davis, supra note 20, at 16-19. 
would solve the problem of constant exportation of coins to England. According to Mather:

[T]hey cannot Keep Silver in the Country ... while the European Trade continues, and that is like to be as long as we are a people. Silver in New-England is like the water of a swift Running River, always coming, and as fast going away .... This our Running Cash is an abiding Cash: for no man will carry it to another Country, where it will not pass; but rather use it here ... and then only the Growths of the Country will be carried off, and that will be no Damage but rather an Advantage to us. ${ }^{152}$

Mather argued that a government paper money would be more stable than private currencies because government officials could manage the currency's stability by means of the government's fiscal powers. Mather characterized public bills of credit as contracts between individuals and the citizenry as a whole. He questioned whether, just as the public is better off by endowing judges with the authority to enforce contracts, all would be better off allowing the government to remedy the need for a medium of exchange by entering debt "contracts" with its citizenry. According to Mather, "can . . . one Magistrate give force to . . Contracts, and cannot All our Government do the same." 153 As is shown below, colonial governments were highly interested in issuing paper currencies and were soon to accept Mather's broader idea.

\section{B. The Structure of Colonial Paper Money Policies}

A year after great successes against the French during King William's War, Massachusetts, New York, and Connecticut sent men to take Quebec, while other troops were sent to attack Montreal simultaneously. ${ }^{154}$ The Quebec expedition met with severe misfortune: Supplies due from England never came, and the troops supposed to attack Montreal returned early,

152. [COTTON MATHER], SOME CONSIDERATIONS ON THE BILLS OF CREDIT NOW PASSING IN NEW-ENGLAND (Boston, n.p. 1691) [hereinafter SOME CONSIDERATIONS], reprinted in 1 COLONIAL CURRENCY REPRINTS, supra note 20 , at 189, 193. Although the pamphlet was circulated anonymously, Andrew McFarland Davis, who compiled the Colonial Currency Reprints, states that the late J. Hammond Trumbull attributed authorship to Mather. 1 COLONIAL CURRENCY REPRINTS, supra note 20, at 196. Cotton Mather strongly advocated the printing of public bills to increase the amount of credit in Massachusetts. According to Mather, "If this [public bills] be made Currant, the Credit of the Colony will rise to the utmost height of it's ability on all Extraordinary Emergencies; ... and if the Merchants cannot Buy as well as Sell for Credit, how shall they carry on their Trades?" SOME CONSIDERATIONS, supra, reprinted in 1 COLONIAL CURRENCY REPRINTS, supra note 20, at 193.

153. Id. at 191 .

154. 1 Thomas hutchinson, The history of the Colony and Province of MASSACHUSETTS-BAY 336-37 (Lawrence Shaw Mayo ed., Harvard Univ. Press 1936) (1764). 
leaving the New England and New York troops to face the entire Canadian army. ${ }^{155}$ Several hundred men were killed by the French and by an outbreak of smallpox, and the rest retreated to Boston. Massachusetts had made no plans to pay the soldiers, expecting that they would be compensated through their own pillage.

The returning soldiers, according to Thomas Hutchinson, were "upon the point of mutiny for want of their wages." ${ }^{156}$ The scarcity of specie in the colony prevented the government from quickly raising the money. The General Court instead issued its first paper money, $£ 7000^{157}$ in "bills of credit" - essentially IOUs-to quell the soldiers' revolt. ${ }^{158}$ The Court announced that bills of credit would be accepted in payment of a tax levied for the next year, so as to give the bills value, and provide security, without requiring a specie reserve. ${ }^{159}$

The government's promise to redeem the bills, however, appears not to have generated market confidence. The bills of credit had so little initial acceptance that the soldiers were able to assign them for only a fraction of their stated value. According to Thomas Hutchinson, "the notes would not command money, nor any commodity at money price," and the soldiers "were great sufferers, and could get no more than twelve or fourteen shillings in the pound." 160 To improve the value of the notes, the government changed its policy to give a five-percent tax discount to those who paid their taxes in bills (as opposed to redeeming them later for funds accumulated by the tax) ${ }^{161}$ The value of the bills changed dramatically and, according to Hutchinson, by the time the general tax approached, the bills "became better than money." Confident that the bills of credit would retain their value, the General Court authorized a larger issue of bills in 1691 and

155. Id. at $337-38$

156. Id. at 340 .

157. The Massachusetts public bills of credit were denominated in pounds, shillings, and pence, although they were entirely distinct from English Sterling.

158. See BROCK, supra note 14 , at 18 . The 1690 order of the General Court is reprinted in 1 DAvis, supra note 150 , at 10-11.

159. A contemporary pamphlet argued that government bills of credit were equivalent to silver coin:

What is the use of Coyned Silver? but to furnish a man with Credit, that he may obtain from his Neighbours those Commodities, which he hath occasion for? The Country in General Court, have Recognized or Acknowledged, a Debt of so many thousand pounds unto them that have been the servants of the Publick. The Credit conveyed by the Bills now Circulates from one hand to another as mens dealings are, until the Publick Taxes call for it. It is then brought in to the Treasurers hands, from which it goes not out again. Now the Conveniences which the servants of the Publick, have had by them, have honestly paid the Countries Debts; and what could coyned Silver have done more? SOME ADDITIONAL CONSIDERATIONS ADDRESSED UNTO THE WORSHIPFUL ELISHA HUTCHINSON ESQ. (Boston, n.p. 1691), quoted in 1 DAVIS, supra note 150, at 13-14.

160. 1 HUTCHINSON, supra note 154 , at 341 .

161. See BRoCK, supra note 14, at 22. 
according to Hutchinson, "[t]he charges of government were paid in this manner from year to year." 162

After 1690, the Massachusetts government began to issue paper money annually in the form of bills of credit to pay public debts. The government typically printed bills of credit and paid them directly to people to whom it owed money, primarily those on salary, those engaged in public works projects, and soldiers. As with the first bills of 1690, the statutes authorizing the bills' issuance included provisions for taxes to be imposed in specific future years when the bills could be either used in payment of taxes or redeemed with general funds. ${ }^{163}$ The value of the bills thus derived from the fact that they could be used to pay taxes or would be redeemed by the government for hard money after a designated date. ${ }^{164}$

In 1714 , complaints of currency scarcity led the government to adopt a second mechanism that distributed bills of credit more widely. The government began issuing large quantities of bills to loan out at interest. The government loaned $£ 50,000$ in bills in 1714 and $£ 100,000$ in $1716 .^{165}$ The system was formalized in 1721 , when the government began lending money through loan offices established in towns throughout the colony. ${ }^{166}$ The security of the loan office bills derived from the fact that they could be used to pay off the principal of the loans (they would be accepted at par value, then destroyed) or redeemed by means of general funds after a designated date. ${ }^{167}$ The taxation provisions and loan agreements for the two forms of paper money issues proved to be the principal mechanism by which the government controlled the quantity of currency in circulation. Monetary policy united with taxation policy.

The issuance and circulation of government paper money had unintended consequences: Contemporary accounts universally agree that, as the number of bills in circulation grew, silver and gold coins were exported

162. 1 HUTCHINSON, supra note 154 , at $341 \&$ n.*.

163. See, e.g., An Act for Making the Former Bills of Credit To Pass Currant in Future Payments (1692), reprinted in WRIGHT \& POTTER, 1 THE ACTS AND RESOLVES PUBLIC AND PRIVATE OF THE PROVINCE OF MASSACHUSETTS BAY 35-36 (1869); see also BROCK, supra note 14, at 18-19 (describing tax provisions associated with specific emissions of bills of credit); 1 DAVIS, supra note 150, at 88-89 (same).

164. See BROCK, supra note 14, at 26-28. Although in the first few years the govemment redeemed the bills within a year of when they were issued, beginning in 1702 the bills were left outstanding for longer periods in response to colonists' complaints of currency scarcity. See NETTELS, supra note 44 , at $257-58$ n.31.

165. BROCK, supra note 14 , at 23.

166. NETTELS, supra note 44, at 257-58 n.31; Bruce D. Smith, Money and Inflation in Colonial Massachusetts, 8 FED. RES. BANK MINN. Q. REV. 1, 4 (1984). The government required that the loans be secured by mortgages on land or on gold or silver plate, that they not exceed one half the value of the asset mortgaged, and that they be paid back in a set number of years. See Smith, supra, at 4.

167. See BROCK, supra note 14 , at 28. 
in even greater volume and were rarely seen or used in commerce. ${ }^{168}$ By 1713 to 1715 , bills of credit became the most widely used medium of exchange throughout the New England colonies. ${ }^{169}$ According to Thomas Hutchinson, by 1710 , "silver and gold were entirely banished. ... [and] the price of everything bought or sold was no longer compared therewith, but with the paper bills, or rather with meer ideal pounds, shillings and pence." ${ }^{170}$ The most plausible reason for this transition is that the existence of the bills of credit reduced the demand for silver and gold in domestic transactions in comparison to their demand in trade with foreign creditors, leading to increased exports of coin. ${ }^{171}$

Thereafter, bills of each of the New England colonies commonly circulated at par throughout neighboring colonies. ${ }^{172}$ In 1712 , in response, the Massachusetts government enacted a law prohibiting execution on the

168. Ronald Michener, Fixed Exchange Rates and the Quantity Theory in Colonial America, in EMPIRICAL STUDIES OF VELOCITY, REAL EXCHANGE RATES, UNEMPLOYMENT AND PRODUCTIVITY 233, 293-94 (Karl Brunner \& Allan H. Meltzer eds., Carnegie-Rochester Conference Series on Public Policy No. 27, 1987).

169. See 1 Davis, supra note 150, at 20-21. The Connecticut government encouraged the transition to wider use of paper money by passing a law forbidding payment of taxes in country pay in 1710 , the year it first issued public bills. See HENRY BRONSON, A HISTORICAL ACCOUNT of CONNECTICUt CuRrenCy, CONTINENTAL MONEY, AND THE FinANCES OF THE REVOLUTION 37 (photo. reprint n.d.) (New Haven, Thomas Stafford 1865).

170. 2 HUTCHINSON, supra note 154, at 154.

171. The export of gold and silver coins due to the circulation of paper money can be characterized as a variation of Gresham's Law-that cheap money drives out dear money. Gresham's Law explains the effect of a fixed exchange rate between two currencies. As the real values of the currencies change in relation to their nominal values, the market will dump the overvalued currency and hoard the undervalued. According to Gresham's Law, then, currencies of different value can coexist as long as they are interchangeable without a fixed exchange rate. See MiLton FRIEDMAN \& ANNA JaCOBSON SCHWARTZ, A MONETARY History OF THE UNITED STATES, 1867-1960, at $27 \&$ n.16 (1963). Massachusetts did not establish a fixed exchange rate between its bills of credit and gold and silver coins and, therefore, the export of gold and silver upon the circulation of paper money is not an example of Gresham's Law defined strictly. The essence of Gresham's Law, however, is that the relative values of currencies will determine where and when they circulate. The wider availability of bills of credit after 1710 decreased the demand for gold and silver coins in domestic transactions. Gold and silver became more exclusively used in international trade, because foreign creditors typically were reluctant to accept Massachusetts's bills.

172. See BROCK, supra note 14, at 35-36; MCCUSKER, supra note 48, at 131-37; Bruce D. Smith, American Colonial Monetary Regimes: The Failure of the Quantity Theory and Some Evidence in Favour of an Alternate View, 18 CAN. J. ECON. 531, 543 \& n.9 (1985). After 1719, Connecticut taxes could be paid in the bills of credit of Massachusetts Bay, New Hampshire, New York, or Rhode Island. BRONSON, supra note 169, at 37-38. According to William Douglass, who wrote an important pamphlet on New England currencies in 1740, people of Connecticut

[gave] a Currency to the publick Bills of their Brethren, in the neighbouring Colonies of New England.

$\cdots$

This promiscuous Currency in the four Governments of New England, that is, one Colony giving a Currency to the enormous Paper Credit Emissions of one of the other Colonies, has the same Effect as if that Colony did emit Bills of its own.

William Douglass, a Discourse Concerning the CuRrencies OF the BRITISH Plantations IN AMERICA (Boston, S. Kneeland \& T. Green 1740), reprinted in 3 Colonial CURRENCY REPRINTS, supra note 20, at 307. 319-20. 
property of or imprisonment of any debtor who paid his debt in good bills of credit, unless the debtor expressly contracted to pay in a different medium. ${ }^{173}$ This statute, in essence, invested colonial bills with the status of legal tender. As is shown below, the wider use of this form of cash made contractual agreements and, in turn, litigation levels, susceptible to government policies regulating the volume of currency in circulation.

\section{The Legal and Economic Effects of Government Control over Monetary Stability}

The power to issue currency vastly increases the influence of the state over economic affairs. The unprecedented power the government can wield through control of the paper money supply derives from several sources. The Massachusetts government had always tried to control the money supply through regulation of commodity money and by means of policies to overvalue coins to draw them into the colony. But these measures had little effect in comparison to the power to print money directly. Since a higher volume of currency in circulation made government taxation far easier to administer, the power to issue currency greatly increased colonial governments' ability to profit from taxation. Under the older regime of scarce coins and money substitutes, in contrast, the power to tax was technically limited because the benefit of collecting taxes in commodities was reduced by the high costs of commodity transportation and resale: Collecting taxes in government bills was far easier and less costly than collecting in corn or wheat. ${ }^{174} \mathrm{By}$ means of paper money issues and tax levies, the government could finance far larger operations than before. ${ }^{175}$

173. See An Act To Prevent the Oppression of Debtors (1712), reprinted in 1 THE ACTS AND RESOlVES PUBliC AND PRIVATE OF THE PROVINCE OF MASSACHUSETTS BAY, supra note 163, at 700-01.

174. Taxing in corn was relatively inefficient because of transportation costs. The problem of taxation in an environment where money was scarce was well-known by those advocating a publicly issued currency. According to a 1691 commentator,

If you Require the Taxes in Corn at an overvalue, with I know not what Abatements if they bring in Mony;... And then if the Government pay the charges of Conveyance from Remoter-parts, and bear all Damages afterwards, what will it amount to when all Charges and Damages are allowed; perhaps scarce two shillings to the Government, of five shillings from the Country; and when will the publick Debts be paid? or when will be an end of Taxing? Certainly ... the Tendency of it is only to render the Government odious by a great noise of Taxes....

SOME CONSIDERATIONS, supra note 152, reprinted in 1 COLONIAL CURRENCY REPRINTS, supra note 20, at 192. In 1684, according to the Massachusetts General Court, because of the "great Charges for Transportation of Pay to Boston," Massachusetts amended its taxation policy so that local towns would serve as a clearinghouse-paying out com when the government owed money, and recciving corn from taxpayers. SEveral ORDERS AND LAwS MADE AT THE SECOND SESSIONS OF THE GENERAL COURT, Oct. 15, 1684, reprinted in THE COlonial Laws OF MASSACHUSETTS, supra note $\mathbf{4 4}$, at 325.

175. Currency issuance can also have a socially transformative effect. Taxes paid to the government must represent something like "profits" or "savings"-that is, returns net of 
Finally, government paper money was widely adopted by colonists as a device to reduce the costs of transacting. Colonial governments' control over the volume of currency in circulation thus magnified the governments' influence over economic affairs such that fluctuating currency policies as a result of a variety of political pressures frequently destabilized the colonial economy.

This Section analyzes the implications of reliance on paper money for contractual relations and litigation. Subsection II.C.1 describes how government currency issuance affected the money supply, Subsection II.C.2 analyzes how colonial governments controlled the value and stability of paper money, and Subsection II.C.3 examines the effects of monetary policy on contractual relations. Finally, Subsection II.C.4 analyzes the relationship between currency policies and litigation.

\section{The Effect of Currency Issuance on the Colonial Money Supply}

The increased influence of the government over economic conditions derives from the transformation in the money supply attendant to the widespread issuance of government currency. The government's widespread circulation of paper money led to three principal changes in the colonial money supply, which might be called the "interest rate effect," the "currency substitution effect," and the "contract value effect." The term "interest rate effect" refers to two possible changes in the interest rate with an increase in the volume of currency. First, the "price" of borrowing currency decreases initially as the government reduces the scarcity of liquid money through currency issues. ${ }^{176}$ Greater currency availability and lower interest rates therefore initially led to a greater volume of credit and productive investment. Government issuance of currency in large enough quantities to cause currency depreciation, however, leads to a corresponding increase in interest rates: Creditors will adjust interest rates to compensate for the losses they expected to suffer from depreciation.

The second principal change in the colonial money supply attendant to the issuance of paper money derives from what might be called the "currency substitution effect." Colonists chose to use paper money in transactions as a lower-cost alternative to coins and money substitutes.

household consumption. Taxation in government-issued currency requires people to engage in the market economy, because people have to earn currency to pay their taxes. A policy of currency issuance and tax levies limits individuals' ability to live autonomously, outside the sphere of market relations. For a discussion of the transformative power of government currency circulation in a modern context, see Paul Bohannan, The Impact of Money on an African Subsistence Economy, 19 J. ECON. HIST. 491 (1959), which discusses government currency circulation in twentieth-century Nigeria.

176. MCCUSKER \& MENARD, supra note 128, at 336 (discussing, in particular, how Massachusetts's loan-office issues of bills of credit reduced interest rates). 
Responding to colonists' latent demand for money, the Massachusetts government issued bills in small denominations to serve as the "small change" needed for routine transactions. ${ }^{177}$ Greater availability of currency led to a substitution away from the use of book accounts and commodity money. Bills of credit served as cash and debt obligations increasingly took the form of formal credit instruments requiring repayment in money. ${ }^{178}$ The currency substitution effect was also likely to have led to increased commercialization, specialization, and market development. Greater availability of cash reduced the need for the coincidence of wants, vastly increasing the potential for exchanges. ${ }^{179}$

The third change in the money supply attendant to widespread issuance of paper money may be called the "contract value effect." A government's control over the value of paper money gives it an unprecedented power to determine the value of individual contracts. The policies of Massachusetts and other colonial governments that changed the value of paper money, for example, changed the value of outstanding book accounts, bills, bonds and notes that were payable in paper money, and led to more breaches of

177. See John R. Hanson II, Small Notes in the American Colonies, 17 EXPLORATIONS ECON. HIST. 411, 411 (1980). Hanson defines a "small note" as one of twenty shillings (£1) or less. In 1690 , Massachusetts issued bills of credit in denominations of $2 \mathrm{~s}$., $2 \mathrm{~s} .6 \mathrm{~d}$., $5 \mathrm{~s}$., $10 \mathrm{~s}$., $20 \mathrm{~s}$., $60 \mathrm{~s}$., $100 \mathrm{~s}$. , and $200 \mathrm{~s}$. In 1713, Is. and 1s.6d. and, in 1722, 1d., 2d., and 3d., were added. Id. at 415.

178. Bruce Mann's data from the Hartford County Court reveal a decline in book accounts coincident with the issuance of paper money. The data show that the percentage of book account cases decreased from $82.9 \%$ in 1700 , to $65.5 \%$ in 1710 , to $29.7 \%$ in 1720 , hovering at between $17 \%$ and $21 \%$ in the period between 1730 and 1750 . See MANN, supra note 7 , at $171 \&$ tbl.1.

179. The availability of paper money does not preclude the possibility that, at times, direct exchanges of goods may be preferable to cash exchanges. Barter is typically preferable as a lower cost means of transacting than cash exchanges during both severe price deflation (currency appreciation, liquidity shock) and severe price inflation (currency depreciation). In Part III, I show that, during periods of currency crisis in Massachusetts, colonists reverted to barter as either severe currency depreciation or appreciation made the government's bills of credit undesirable as a medium of exchange. For further discussion of the choice to revert to barter in a monetized economy, see Jürg Niehans, Money and Barter in General Equilibrium with Transactions Costs, 61 AM. ECON. REV. 773 (1971); Ronaleen R. Roha \& Marc L. Schulhof, How Bartering Saves Cash, KiPLinger's Pers. FIN. MAG., Feb. 1996, at 103, 103-04; and Canice Prendergast \& Lars Stole, Barter, Liquidity \& Market Segmentation (Oct. 1997) (unpublished manuscript, on file with author).

According to Ronald Michener, an economist and historian of colonial currencies, the New England bills of credit replaced specie in quantities approximating one-for-one and, therefore, the issuance of these bills of credit did not lead to greater monetization of the economy. For his analysis of the impact of the issuance of bills of credit on specie flows in Massachusetts, see Michener, supra note 168, at 288-94. Legal historians including Bruce Mann and myself have concluded that colonial governments' issuance of bills of credit led to greater monetization of the economy because the legal records reveal a tremendous increase in the numbers of cases based on promissory notes coinciding with the introduction of paper money. Promissory notes are written obligations to pay a sum of money on a specified date. The move away from book account cases to promissory note cases immediately after the transition to exclusive use of paper currency suggests that more money was in circulation. Further work is required in determining the precise nature of promissory notes at the time, however, to understand fully how extensive the monetization was. 
contract and litigation. These relationships are complex and are the subject of the remainder of this Part.

\section{Colonial Monetary Policy and the Potential for Currency Crises}

The value and stability of a currency are determined by a complex interplay between government policies regulating the supply of currency, the extent of private "creation" of money (commodity money, promissory notes, credit, etc.) and currency demand, driven by economic conditions and public expectations. Economists have generally accepted the notion that, in the long run, currency policies may change the volume of nominal currency and, thus the nominal value of goods, but will have little effect on the supply of "real" money, that is, the inherent, not nominal, value of goods and services in an economy. ${ }^{180}$ When governments or private sources increase currency volume at levels beyond the rate of true economic growth, for example, the value of currency will decline (currency will depreciate or prices will inflate) because the volume of real money will be unchanged. ${ }^{181}$ Similarly, governments can cause currency appreciation or price deflation by issuing currency at quantities less than the rate of economic growth. Reduced currency volume may cause short-term economic shocks, such as recessions, but in the long run, only prices will decline, because the volume of real money measuring the real value of goods and services in an economy will remain unchanged. In theory, then, governments can create short-term economic benefits and harms through inflation or deflation, but, in the long run, crises will be abated through price and interest rate adjustments. ${ }^{182}$ These principles of money supply apply to the colonial period as much as they do to today's economy. As is

180. See Charles W. Calomiris, Institutional Failure, Monetary Scarcity, and the Depreciation of the Continental, 48 J. ECON. HIST. 47, 48 (1988) ("Most economists believe the supply of real money in the long run is an endogenous variable, determined independently of the nominal money supply...."). As a simple example, if in real value terms, a cow is worth ten pigs, at an initial currency level, the price of a cow may be $\$ 10$ and a pig $\$ 1$; if the volume of currency doubles, the price of a cow will rise to $\$ 20$ and a pig to $\$ 2$; the inherent comparative value does not change.

181. According to Milton Friedman,

[I]nflation is always and everywhere a monetary phenomenon in the sense that it is and can be produced only by a more rapid increase in the quantity of money than in output. Many phenomena can produce temporary fluctuations in the rate of inflation, but they can have lasting effects only insofar as they affect the rate of monetary growth.

Milton Friedman, MONEY MisChief 49 (1992); see also Milton Friedman, OPTIMUM QUANTITY THEORY OF MONEY AND OTHER ESSAYS (1969) (describing the quantity theory in greater detail).

182. Robert Lucas, for example, states that the "two central implications of the quantity theory of money... [are] that a given change in the rate of change in the quantity of money induces (i) an equal change in the rate of price inflation; and (ii) an equal change in nominal rates of interest." Robert E. Lucas, Jr., Two lllustrations of the Quantity Theory of Money, 70 AM. ECON. REV. 1005, 1005 (1980). 
shown below, what is distinctive about the colonial period is that the volume of currency was so low that periods of currency scarcity disrupted basic economic activity, compelling resort to barter with its many attendant problems.

The conventional quantity theory of money described aboveexplaining the relationships between the volume of currency in circulation, currency value (depreciation or appreciation, price inflation or deflation), and interest rate adjustment-is a basic tenet of monetary economics. It is consistent, moreover, with the theory that government actions that change consumer expectations about the value of currency, other than simply by regulating the volume of currency, can also lead to increases or decreases in currency value. General expectations about currency values were principally affected by the colonial governments' definition and application of the terms of redemption of the bills of credit.

Colonial governments, of course, set forth in the initial offering the redemption terms that established the value of the bills of credit. At offering, the real value of the bills was the present value of redemption. As described above, for some issues, the bills' value derived from the government's promise to accept them for tax payments (or redemption in a particular year); for other issues, the bills' value was the government's promise to accept them as payments against loans. Still, the public's perception of the subsequent enforcement of those agreements-by taxation or through enforcement of the loan agreements-was a principal determinant of the value of the bills. When the public believed they would be retired according to schedule, they remained (for purposes of exchange rates) at the present value of the redemption price. When the public was uncertain about government monetary redemption policy, however, the bills depreciated. An anonymous 1721 pamphlet explained:

[A Man] gives Credit to these Bills; the Country by an Act promises to take them again, at such a time, but do not; Surely, this lessens the Mans Credit of them: I will not, (saith he) Sell so much Silver, or Gold, or Goods, or Houses, or Lands, for the Paper Bills, as I did before. ${ }^{183}$

Periods of currency depreciation-when bills were not redeemedwere similar in effect to periods of price inflation (circulation of currency beyond economic growth). ${ }^{184}$ Similarly, the government's spontaneous

183. THE SECOND PaRT OF SOUTH-SEA STOCK BEING AN INQUiRy INTO THE ORIGINAL OF PROVINCE BILLS OR BILLS OF CREDIT (Boston, D. Henchman 1721) [hereinafter SECOND PART], reprinted in 2 COLONIAL CURRENCY REPRINTS, supra note 20, at 302, 314.

184. See Smith, supra note 172 , at 549. 


\section{decision to retire certain bills could increase the bills' value, leading to currency appreciation or price deflation. ${ }^{185}$}

185. In the economics literature, discussion of the relative importance of the volume of currency in circulation and the enforcement of a government's redemption promises has been characterized as a debate between the "quantity" or "classical" theory of money and the "backing theory" or "anticlassical" position. Proponents of the backing theory argue that the most important determinant of the value of currency is the backing of that currency provided by the government and that, as with stock issues and other private liabilities, when a public currency is fully backed, its value is not strongly determined by the quantity in circulation. Calomiris, supra note 180, at 49; Smith, supra note 172, at 533-34; Smith, supra note 166, at 1-2; Bruce D. Smith, The Relationship Between Money and Prices: Some Historical Evidence Reconsidered, 12 FED. RES. BANK MINN. Q. REV. 18, 18-19 (1988); Bruce D. Smith, Some Colonial Evidence on Two Theories of Money: Maryland and the Carolinas, 93 J. POL. ECON. 1178, 1187-88 (1985) [hereinafter Smith, Two Theories of Money]. The proponents of the backing theory argue that it has two principal advantages over the quantity theory. First, the backing theory provides a better explanation of currency and price data. Bruce Smith, its principal proponent, performed several empirical studies of inflationary trends during the colonial period (including an examination of Massachusetts in the period from 1710 to 1750 , described in Part III). Smith demonstrated that the volume of bills of credit in circulation was often less determinative of inflation than the refusal of colonial governments to retire the bills of credit according to stated policies. In his study of Maryland and the Carolinas, for example, Smith found that the Carolinas experienced rapid depreciation of currency value during periods of little change in currency volume, but in which governments failed to retire their bills. Smith, Two Theories of Money, supra, at 1188-99 \& tbls.12. In contrast, Maryland was able to increase and decrease dramatically its supply of bills of credit with relatively little effect on the value of the bills, because it consistently backed its currency. Id. at 1199-1208 \& tbl.4. Ronald Michener has criticized Smith for emphasizing colonial paper monies that the government promised to redeem in specie on a particular date and therefore that functioned more like bonds than "moncy." Michener, supra note 168, at 242-45. Michener's view is that the stability of a colonial currency was principally affected by whether the colony had a de facto fixed exchange rate. In colonies where merchants adhered to a fixed exchange rate with specie by custom, the governments' bills of credit were relatively stable in value. According to Michener, however, because specie was entirely absent in New England between 1710 and 1750, there was no such customary fixed exchange rate, and the bills of credit depreciated when they were issued in large volumes. Id. at 237.

A second reason why some economists have favored the backing theory, however, is that it supports colonists' own views about currency scarcity. According to the quantity theory, currency cannot be "scarce" in the long run. A reduction in the volume of currency leads eventually to a general price decline, with no effect on the real money supply. According to the backing theory, however, the value of currency is not likely to decline below the present value of its redemption price. A decrease in the volume of fully backed currency, for example, will not lead to a proportional price decline and interest rate increase, meaning that it is possible for there to be a suboptimal volume of currency in circulation. For example, according to the economist Charles Calomiris:

If government policy can costlessly increase the long-run level of consumer surplus enjoyed by moneyholders, then the failure to implement that optimal policy makes money unnecessarily scarce.... [C]omplaints of monetary scarcity and calls for government actions to increase the supply of paper money were often reasonable exhortations for institutional reform, rather than merely attempts to extinguish specie debt with depreciated paper, or evidence of unsophisticated cconomic analysis.

Calomiris, supra note 180 , at $48-49$. Of course, it is very difficult to measure the quantity of money in circulation precisely. Indeed, Smith and the backing theory proponents have been criticized for examining only bills of credit and ignoring flows of gold and silver coins and the creation of private money (credit, bills, notes, etc.). Bennett T. McCallum, Money and Prices in Colonial America: A New Test of Competing Theories, 100 J. POL. ECON. 143 (1992); Ron Michener, Backing Theories and the Currencies of Eighteenth-Century America: A Comment, 48 J. ECON. HIST. 682 (1988). 
As the next Part describes, the government, faced with political pressures not to redeem the bills on schedule, often ignored the initial redemption terms. During the 1730 s, the period that is the focus of this Article, the government's failure to adhere to its redemption schedule was the principal determinant of fluctuations in the value of the colonial bills of credit. As is shown below, the public's expectation that the bills would not be redeemed (in other words, that there was no real security for the bills' value) lowered the value of the bills regardless of the demand for currency. Indeed, traders reverted to barter when the bills in circulation depreciated quickly and had no cognizable value.

\section{Currency Policies, the Common Law, and Contractual Relations}

Government policies affecting the value of currency in circulation also directly affect the value of existing contractual obligations when terms are fixed. During an inflationary period-when currency depreciates-those obliged to make monetary payments in the future in some set, nominal amount may pay their debts in reduced amounts in real terms. Those receiving salaries in fixed nominal terms, for example, receive less in real terms when they are paid in depreciated currency. Conversely, in times of currency scarcity, when the value of currency appreciates, the real value of debts increases. Debtors pay more in real money than they had agreed; those on fixed salaries receive more than they had anticipated.

There are two necessary conditions for currency policies to affect all contract values systematically in these ways. First, whether depreciating or appreciating, currency must be designated by law to be legal tender for the purpose of repayment of debts. If the currency is legal tender, creditors are obliged by law to accept it in satisfaction of a debt. In contrast, if a currency is not legal tender, a creditor need not accept it; thus, debtors cannot gain from depreciation and must satisfy the debts in agreed-upon terms. Massachusetts enacted the first statute designating bills of credit as legal tender in $1712 .^{186}$

Second, if currency policies are to affect economic obligations, judges must apply the doctrine of "nominalism." Nominalism simply means that payment of the nominal value of a debt satisfies one's legal obligation: That

Presenting the quantity theory and the backing theory as contrary positions, however, oversimplifies the quantity theory. The quantity theory does not preclude the possibility that expectations about government policy will affect the real value of a currency. Milton Friedman, Quantity Theory of Money, in THE NEW PALGRAVE: MONEY, supra note 33, at 26-30; see also Scott Sumner, Colonial Currency and the Quantity Theory of Money: A Critique of Smith's Interpretation, 53 J. ECON. HIST. 139, 141 (1993) (criticizing Smith for not recognizing that, under the modern version of the quantity theory, "anticipations of future changes in the money supply may lead to large changes in real currency demand").

186. See supra note 173 and accompanying text. 
is, that judges do not adjust debt amounts to account for changes in the value of the debts in real terms. The nominalist principle has been a consistent feature of the common law since 1605, when The Case of Mixed Money ${ }^{187}$ established the sovereign power of the Crown to designate the form and the value of currency serving as legal tender. ${ }^{188}$ Although colonial judges and juries were not bound by all common-law rules, it is fairly clear that the nominalist doctrine was applied throughout the currency crises of the 1730 s and early 1740 s, until the doctrine was overturned by statute in $1742 .{ }^{189}$ In a 1743 pamphlet, one writer claimed there never " had been any Instance of more than the nominal Sum of the Bills express'd in the Condition . . . ever being paid, or demanded in a Court of Judicature 'till 1742." 190 As is shown below, nominalism and legal tender rules propelled parties to use legal process to gain from changing currency values.

Even judges applying the nominalism doctrine, however, respected written private agreements to adjust debt obligations in response to changing currency values. A 1730 case, for example, enforced a provision in a contract stating that the debt was to be repaid "Either in Silver Money at Sixteen Shillings per oz. or in Good Bills of Creditt on this Province at the Election of [the plaintiff]." 191 It is somewhat curious that these types of agreements were not more widespread. Thomas Hutchinson stated that debts on specialties-debts under seal—were adjusted for depreciation and that those cases represented one-eleventh of the entire caseload. ${ }^{192}$ As is shown below, one explanation for why they were not used more frequently was that the government routinely expressed a commitment to maintaining the value of the bills of credit. Furthermore, there was little money in circulation other than bills of credit in which to pay debts.

187. 2 State Trials $114 ; 80$ Eng. Rep. 507 (P.C. 1605).

188. KeITH S. ROSENN, LAW AND INFLATION 39-40 (1982); see also F.A. MANN, THE LEGAL ASPECT OF MONEY 80-175 (4th ed. 1982) (examining the history and effects of judicial application of the nominalism principle in Britain). According to Mann, "[I]n England the unimpaired control of nominalism has never been doubted. English law lacks all equipment that, in the case of liquidated sums, could lead to a revision or adjustment of the substance of the obligation." MANN, supra, at 107.

189. See infra notes 306-309 and accompanying text.

190. AN ENQUiRY INTO THE STATE OF THE BILls OF CREDIT OF THE PROVINCE OF MASSACHUSETTS-BAY IN NEW ENGLAND IN A LETTER FROM A GENTLEMAN IN BOSTON TO A MERCHANT IN LONDON (n.p. 1743), reprinted in 4 COLONIAL. CURRENCY REPRINTS, supra note 20, at 149, 185 [hereinafter ENQUiRY]; see also PERKINS, supra note 140, at 174-78 (discussing the colonial problem of debt payment in depreciated currency).

191. Sever v. Segar, Common Pleas (Mar. 1731), in 5 PLYMOUTH COURT RECORDS, supra note 77 , at 370 No. 74 . Similarly, the Hancock families' business records include a 1742 reference to a lease that provided that the rent would be adjusted "in respect of the rise or fall of Money." BAXTER, supra note 69 , at 33 (quoting the lease).

192. 2 HUTCHINSON, supra note 154, at 335 (" [A]lthough debts on specialties had allowance made in judgments of court for depreciation of the bills, yet on simple contracts, of which there were ten to one specialty, no allowance was made."). 


\section{Currency Policies and Individuals' Litigation Strategies}

As described above, Massachusetts courts required that debtors pay only the nominal sums owed in their contracts, no matter how extreme the subsequent changes in currency value throughout the period from 1712 to 1742. Such a policy has substantial implications for litigation. Once the terms of a contract are established, debtors are likely to respond to changes in currency value by using the legal process to affect the timing and thus the value of their payments. As litigation is a mechanism to enforce contracts, creditors are likely to respond to debtors' actions by choosing when to sue. As is shown below, both inflation and deflation are likely to lead to greater litigation.

There are two basic types of contracts involving payment of money: contracts to pay money, that is, debt contracts; and contracts for some performance to be compensated by money at a future time, such as contracts for labor or to deliver goods. Both the actions of the person owing the money or the performance and the responses of the party to whom the money or services are owed are likely to be affected by changes in currency value when terms are fixed. With respect to monetary loans, it is in the short-term interest of debtors to use the timing of repayment to benefit or recoup losses from currency value changes. When currency values are declining (depreciation or price inflation), for example, debtors have an incentive to delay payment while the value of the debt decreases, as prices inflate. Creditors, in response, will sue to reclaim the debt so as not to lose value of the contract over time. In this case, litigation is a likely outcome.

When currency values are increasing, debtors are likely to pay their debts as quickly as possible to avoid the increases in the real value of the debts. If a debtor prepays, obviously, there will be no litigation. Increasing contract values may, however, lead to default and litigation of a different sort. An increase in contract values is equivalent in effect to an increase in the interest rate: When currency appreciates, debtors have to pay more in real money than they received. Economists generally accept the proposition that a rise in the interest rate decreases the likelihood that debtors will be able to profit from low-risk investments and thus creates a moral hazard problem, encouraging debtors to invest in high-risk investments, which leads to an increase in the rate of default. ${ }^{193}$ When debtors default, of course, creditors are likely to sue to reclaim money owed them. Creditors may benefit because the value of that money is higher. Because increases in currency value are similar in effect to increasing the interest rate for all outstanding debt contracts, however, it is possible for increases in currency

193. See, e.g., Joseph E. Stiglitz, The Causes and Consequences of the Dependence of Quality on Price, 25 J. ECON. LIT, 1 (1987). 
value to increase general default levels, which would represent a loss to many creditors. Indeed, during periods of severe currency scarcity, there can be "chains of debt" when those who owe money, but cannot pay, must sue those who owe them to pay back their debts, raising the general level of litigation. ${ }^{194}$

With respect to contracts for the future performance of services (such as wage contracts) or to deliver goods, the performing party is likely to respond to changes in the value of currency by deciding whether or not to withhold labor or delivery. When currency depreciates, the value of the performance increases in relation to the value of money. The party will breach when the value of performance exceeds the value of the compensation. ${ }^{195}$ A laborer, for example, is likely to breach an employment agreement when his or her labor is greater in value than his or her contracted wage. In the case of breach by the performing party, the disappointed recipients are likely to sue to enforce the contract. In contrast, when currency appreciates, the performing party is likely to adhere to the contract to gain the benefits of increasing compensation, while the paying party may breach.

Many colonial citizens had initially believed that either a private or government-issued paper currency would reduce overall litigation levels. There were two principal arguments for why the transition to the cash economy would reduce lawsuits. First, colonists imagined that economic advances resulting from the transition to a cash economy would reduce the number of debt obligations each individual required in the course of his or her business activities and daily life. A decreased number of debt obligations, it was argued, would decrease the extent to which debts for very minor transactions would result in court action. Captain Blackwell, the promoter of a private currency, for example, argued in 1687 that with the issuance of money, "[a]ll sorts of persons become inabled to live handsomly, and out of Debt: and that prevents multiplicity of Lawsuites, charges, and troubles to the Government." 196

Second, colonial citizens argued that an increase in credit availability resulting from the widespread availability of a ready currency would allow debtors with assets to acquire credit in times of emergency, so that they could perform on their existing debts and avoid a lawsuit and execution on

194. See Rosen, Courts and Commerce, supra note 7, at 146; see also Jonathan M. Chu, Debt Litigation and Shays' Rebellion, in IN DEBT TO SHAYS, THE BICENTENNIAL OF AN AGRARIAN REBELLION 82-83 (Robert A. Gross ed., 1993) (describing how deflation and recession accelerated the calling in of promissory notes by creditors in Massachusetts in 1785, leading to Shays' Rebellion).

195. See Alan Schwartz, Sales Law and Inflations, 50 S. CAL. L. REV. 1 (1976).

196. DISCOURSE, supra note 118 , reprinted in 1 COLONIAL CURRENCY REPRINTS, supra note 20 , at 130 . 
their property. According to an anonymously written 1714 pamphlet, with greater issuance of currency and the existence of a bank,

the Landed man might ... borrow Credit without any fear of a sudden or surprizing demand, to the prejudice of his Affairs, might Stock his Farm, and be less able to lessen his Principal, as his Product would enable him; it would be a certain resort for men to borrow Credit on any Emergency. ${ }^{197}$

Unfortunately, as is shown below, the instability of colonial currency policies meant that the opposite was the case: Currency gluts and currency scarcity led to widespread economic stagnation that, in turn, propelled high levels of litigation, which swamped court dockets.

\section{CURRENCY POLICIES IN MASSACHUSETTS, 1710-1750}

This Part presents a history of currency policies in Massachusetts from 1710 through 1750. The proponents of the modernization hypothesis characterize the period from 1710 to 1740 as the period during which New England judges adapted the law in response to, and as a stimulus for, greater economic growth and commercialization. This was, however, a period during which currency policies were highly unstable. Indeed, Baxter's analysis of the Hancock records led him to conclude that "from the beginning of Thomas [Hancock's] career (1717) until at least 1750, the currency with which he had to carry on his business was in a state of chaos." ${ }^{198}$ According to Baxter, "a well-ordered monetary system was still a rare blessing in any part of the world ... [but] the financial muddling of Massachusetts and her neighbors was remarkable even for the age." 199

Currency policies in Massachusetts were unstable because they were developed and enacted amidst constant political struggles within the colonial government. The colonial assembly responded to popular complaints of an insufficient volume of currency in circulation both by ignoring the provisions to retire bills of credit through taxes at designated times, and by circulating new issues of the bills. The English Board of Trade, in contrast, responded largely to English creditors, who lost money when colonial currencies depreciated, by insisting that the Governor

197. A LETTER, FROM ONE IN BOSTON, TO HIS FRIEND IN THE COUNTRY (Boston, n.p. 1714), reprinted in 1 COLONIAL CURRENCY REPRINTS, supra note 20, at 263, 286.

198. BAXTER, supra note 69 , at 12 (emphasis added).

199. Id. at 11. Later Baxter states that the state of currency during the first half of the eighteenth century required businesses to be run in a manner closely similar to those of "medieval merchants" who suffered from similar problems. According to Baxter, with respect to currency issues, "Thomas [Hancock] was ... much closer to the twelfth than to the twentieth century." Id. at 16. 
maintain stringent currency policies. The Massachusetts assembly was influenced by the Governor's demands, but in large part ignored them. The resulting policies generated highly unstable currency values, with a trend towards increasing currency depreciation. Section III.A examines how Massachusetts's early currency policies affected economic and legal conditions in the period from 1710 to 1725 . Section III.B then examines in greater detail the currency events of 1726 to 1742 , which resulted in the highest litigation volume of the first half of the eighteenth century.

\section{A. Expanding the Money Supply, 1710-1725}

As described earlier, Massachusetts's bills of credit coexisted with gold and silver coins throughout the first two decades of their circulation, from 1690 to $1710 .^{200}$ During this period, the volume of bills issued was small and the value of the bills remained relatively stable. ${ }^{201}$ During the period from 1713 to 1714 , despite the greater circulation of the paper money, ${ }^{202}$ the citizens of New England experienced dramatic monetary scarcity. Bills of credit constituted the exclusive currency in New England-gold and silver coins were no longer available at all-but the bills of credit were not sufficiently voluminous to satisfy the demand for a medium of exchange. At this time, the New England colonies' currency problems became a central political issue, and would remain so throughout the first half of the century.

There was substantial controversy over how to remedy the problem of inadequate currency. In 1714, several Massachusetts investors, led by Elisha Cooke, Jr., and John Colman, presented a plan to the government to create a private bank, backed by land, that would issue $£ 300,000$ in paper money to be used as a circulating medium. ${ }^{203}$ Others maintained that the only solution was to cease issuing paper money and return to a hard-money standard. ${ }^{204}$ Still others believed that the government could resolve currency

200. 1 DAVIS, supra note 150 , at 107; JOSEPH B. FELT, AN Historical ACCOUNT OF MASSACHUSETtS CURRENCY 63 (Boston, Perkins \& Marvin 1839).

201. See 1 DAVIS, supra note 150, at 107; FELT, supra note 200, at 63.

202. In 1711, the government lent $£ 50,000$ in bills of credit to a group of Boston merchants to furnish supplies to the Hill and Walker military expedition against Quebec (which was part of Queen Anne's War, 1702-1713). This loan was sufficient in volume to lead to an exportation of all specie. See 1 DAVIS, supra note 150 , at 54 . On the exportation of coins, see supra notes 169 171 and accompanying text.

203. See Gary B. Nash, The Urban Crucible: Social Change, Political CONSCIOUSNESS AND THE ORIGINS OF THE AMERICAN REVOLUTION 81-82 (1979); George Athan Billias, The Massachusetts Land Bankers of 1740,61 U. ME. BULL. 1, 3-5 (1959).

204. FeLT, supra note 200, at 64. In 1718, for example, Governor Shute declared that "We shall never be upon a firm and lasting foundation, 'til we recover and return to silver and gold, the only true species of money." I DAVIS, supra note 150, at 61. An anonymous 1721 pamphlet advocated a return to hard currency. SECOND PART, supra note 183 , reprinted in 2 COLONIAL 
scarcity by issuing more bills and by delaying redemption of the bills in circulation. According to the historian Gary B. Nash, the proposal for the private land bank was rejected by popular vote at a Boston town meeting that drew the highest volume of attendance in Boston's history. ${ }^{205}$

The Massachusetts government subsequently adopted three principal measures to remedy currency scarcity. First, it continued to issue more bills of credit. In response to the town-meeting vote, for example, the government issued $£ 50,000$ in 1714 and $£ 100,000$ in 1716 , which it lent directly to individual citizens at an annual interest rate of five percent. ${ }^{206}$ Second, the government extended the duration that bills of particular issues would remain outstanding prior to retirement. The government's first issues, from 1690 to 1703 , were to be retired after one year. ${ }^{207}$ Bills issued between 1704 and 1706 were to be retired within two years. ${ }^{208}$ Beginning in 1707, however, the government progressively extended the period from issuance to retirement. ${ }^{209} \mathrm{By} 1722$, the government designated an issue of

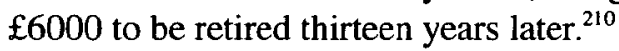

Finally, for the first time in 1715 , the Massachusetts government declined to impose the taxes required to retire bills according to schedule. ${ }^{211}$ Although the bills of credit were generally retired on schedule before

CURRENCY REPRINTS, supra note 20, at 303-32. The hard-money position gained increasing support during the 1730s. I DAVIS, supra note 150, at 84-85.

205. NASH, supra note 203, at 82; see also Billias, supra note 203, at 3-5 (describing John Colman's petition for a private bank and its rejection by the government).

206. See, e.g., An Act for the Making and Emitting the Sum of Fifty Thousand Pounds in Bills of Credit on This Province, in Such Manner as in the Said Act Is Hereafter Expressed (1714), reprinted in 1 THE ACts and Resolves Public and PRIVATE of THE PROVINCE of MASSACHUSETTS BAY, supra note 163, at 750-51. The government alleged that "the publick bills of credit on this province ... are now grown very scarce, and few of them passing in proportion to the great demand of the same." Id.

207. NETTELS, supra note 44 , at 257 n.31.

208. I DAVIS, supra note 150 , at 89.

209. The 1707 bills were to be retired after three years; part of the 1709 bills were to be retired after five years; the 1711 bills, after six years; and the 1712 bills, after twelve years. $I d$.

210. Id. With respect to currency issues lent to private investors, the government was less flexible about the repayment schedule. When the government, for example, issued $£ 50,000$ to a group of merchants to supply the Hill-Walker expedition against Quebec in 1711 , it required that the issue be redeemed within two years. In that particular case, however, the redemption was made possible by grants of bills of exchange payable in Sterling given to the government by British agents. NETTELS, supra note 44 , at 258 n.31.

211. Davis writes:

In June 1715 , the representatives asserted that the trade of the province was greatly obstructed by the exportation of coin; that the only medium of exchange then passing was bills of credit; that so few of these were in circulation that it would occasion trouble to call in the bills which by the terms of the resolves under which they were issued should by right be called in that year; as a remedy for the trouble they proposed that a part only of these bills should be called in.

1 DAVIS, supra note 150 , at 55. 
$1721,{ }^{212}$ after 1721 , they were frequently not retired on schedule. Similarly, loan repayment agreements were often not enforced. ${ }^{213}$

Despite these various measures, the volume of currency in circulation still failed to satisfy the need for a medium of exchange. Indeed, the Massachusetts currency experience in the first half of the eighteenth century appears to present a paradox. Although the volume of government paper money in circulation increased, the advantages of the widespread currency circulation were at times entirely defeated: Massachusetts's currency consistently depreciated, and there were periods when money was so scarce that there was a general reversion to barter exchanges. ${ }^{214}$

How could this happen? The most plausible explanation is that the uncertainty generated by the government's unstable currency policies overwhelmed the otherwise mechanical effect of an increase in the volume of currency. The government's failure to retire bills according to schedule increased the number of bills in circulation, but undermined market expectation of the bills' nominal value. Because the provisions for taxation and redemption established the bills' security and value, the government's failure to retire the bills on schedule led to a steady market decline in the Massachusetts bills' value in relation to English Sterling and Spanish pieces of eight. Similarly, lengthening the duration that bills would remain outstanding also led to depreciation because the return on the investment in the bill-redemption or use of the bills to pay taxes-could be realized only years into the future. ${ }^{215}$ Thus, despite the government's efforts to increase the nominal value of currency, the volume of real money (money adjusted for currency value) remained unchanged or declined. Figures 1 and 2 show these relationships. Figure 1 displays an estimate of the volume of currency per capita for New England from 1719 to $1749 .{ }^{216}$ Note that these are estimates for all of New England. Figure 1 generally confirms the

212. BROCK, supra note 14 , at 31 .

213. Theodore Thayer, The Land-Bank System in the American Colonies, 13 J. ECON. HIST. 145,157 (1953).

214. E.g., Money THE Sinews of Trade: The State of the Province of THE MASSACHUSETTS-BAY CONSIDERED, WITH RESPECT TO ITS TRADE FOR WANT OF A MEDIUM OF EXCHANGE WhEREWITH To MANAGE IT (Boston, S. Kneeland \& T. Green 1731), reprinted in 2 COLONIAL CURRENCY REPRINTS, supra note 20, at 431, 432 (predicting a return to barter); [JOHN WISE], A WORD OF COMFORT TO A MELANCHOLY COUNTRY (Boston, n.p. 1721) [hereinafter A WORD OF COMFORT], reprinted in 2 COLONIAL CURRENCY REPRINTS, supra note 20, at 158, 165-66 (describing reliance on barter during the crisis of 1720); To the Author of the Weekly Rehearsal (Mar. 4, 1734), in 3 COLONIAL CURRENCY REPRINTS, supra note 20, at 61, 67-68 (discussing barter during the crisis of 1733); references provided infra note 224 (same). See infra note 267 for references to the widespread reversion to barter during the crisis of 1738-1741.

215. Colonists holding bills that could only be redeemed after five or six years also faced the risk that subsequent colonial assemblies might not honor the redemption promises made with each issue of bills.

216. McCallum calculated the total number of bills of credit in New England (including the Merchant's Notes of 1733, described infra text accompanying notes 253-258) in terms of English Sterling, and divided by per capita figures taken from the U.S. Census Historical Statistics. 
contemporary accounts of reversion to barter. After 1712, per capita bill of credit holdings reached the lowest points in 1720, 1730, and 1737-1742. I discuss later the significance of the substantial increase in money supply after 1745 .

FiguRE 1. BILlS Of CREDIT PER CAPITA: NEW ENGLAND, 1709-1749

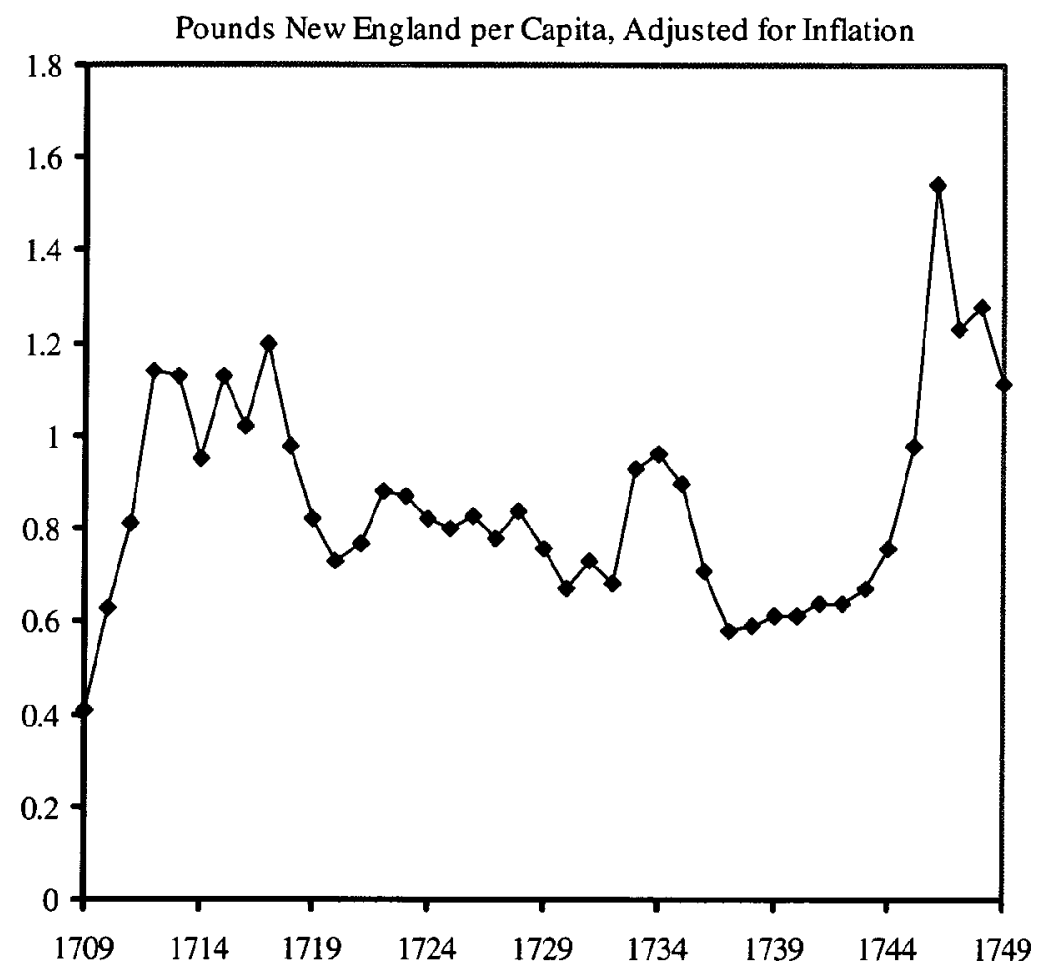

Source: Bennett T. McCallum, Money and Prices in Colonial America: A New Test of Competing Theories, 100 J. POL. ECON. 143, 150 tbl.2 (1992).

Next, Figure 2 shows the depreciation of Massachusetts bills in relation to English Sterling over the same period. Figure 2 presents Massachusetts data alone and so does not exactly correspond to Figure 1, though the experience was similar. Figure 2 shows the value of $£ 100$ Sterling in Massachusetts currency by year. As is evident from Figure 2, while in 1700 the Massachusetts pound traded slightly above par ( $£ 133$ Mass. $=£ 100$ Sterling), the period from 1720 to 1735 was a time of steady depreciation: The value of Massachusetts bills of credit declined by more than half. 
Depreciation rapidly accelerated after 1735 to equal 7.9 times par in 1749. ${ }^{217}$

\section{FIGURE 2. DEPRECIATION OF MASSACHUSETTS BILLS}

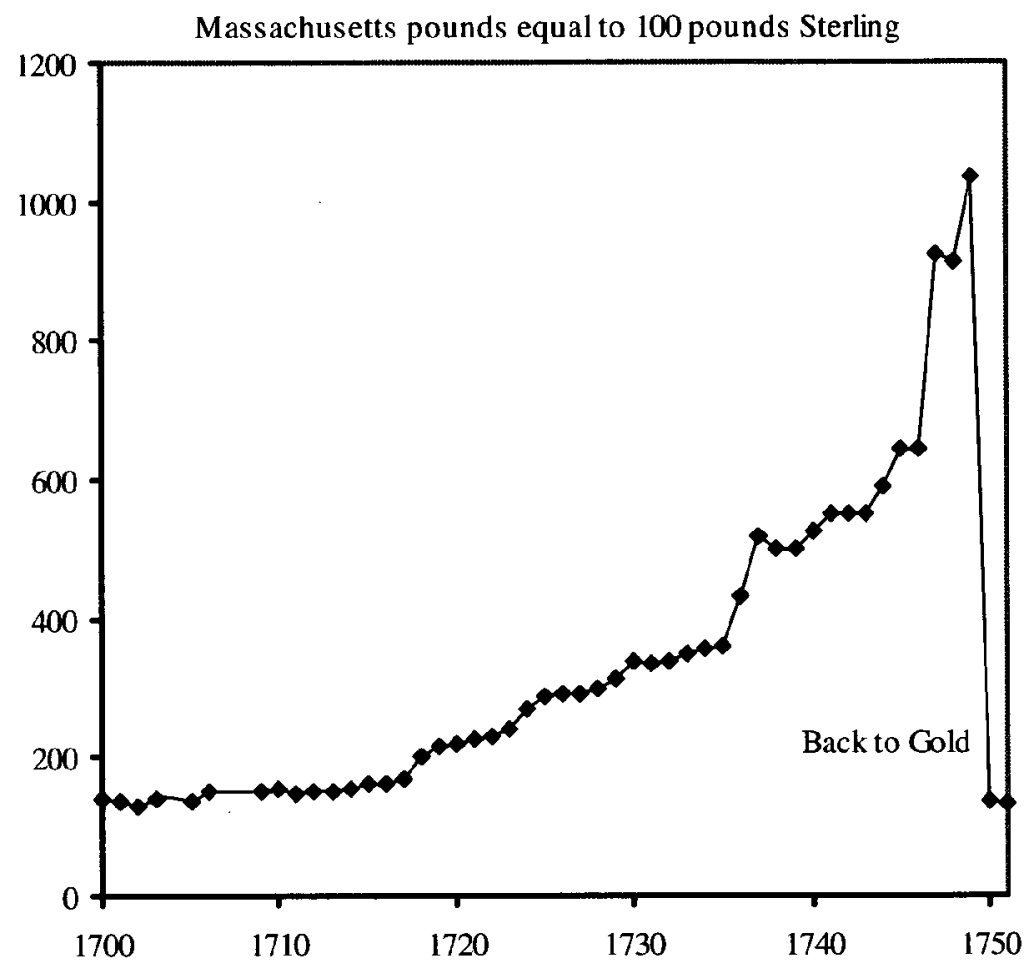

Source: JoHn J. MCCuSKER, Money AND EXChange IN EUROPE AND AMERICA, $1600-1775$, at $139-41$ tbl.3.1 (1978).

Figures 1 and 2 substantially challenge the steady economic growth hypothesis of the modernization theorists. Quite in contrast to this hypothesis, they suggest that currency problems are the fundamental reason behind the low economic growth estimates of the period made by economic historians, mentioned earlier. ${ }^{218}$ New England and Massachusetts, in particular, were plagued by unstable and inadequate currency, requiring

217. The increasing depreciation during the period from 1735 to 1750 is discussed in the next Section. The Sterling exchange rate does not precisely reflect changes in the Massachusetts currency value because exchange rates are also affected by the balance of payments and international economic and monetary conditions. But the constant depreciation of Massachusetts's bills of credit against English Sterling is strongly suggestive of the declining value of the bills of credit.

218. Supra note 126 and accompanying text (estimating $0.5 \%$ per capita annual growth). 
frequent resort to barter between 1713 and 1714, between 1720 and 1721, between 1726 and 1727, and between 1738 and 1741. As explained in Part I, resort to barter is the antithesis of economic prosperity. And the currency that was available to Massachusetts citizens was steadily declining in real value, with an accelerating decline after 1735 - suggesting, again, the opposite of steady economic growth toward modernization.

As described earlier, the volume of litigation is affected by unstable currency policies. Depreciation in particular affects debt litigation when bills of credit are designated as legal tender and when judges apply the doctrine of nominalism. Bills of credit were given status as legal tender in 1712, when Massachusetts residents became exclusively reliant on them as a medium of exchange. ${ }^{219}$ Government officials believed that treating bills of credit as legal tender would reduce depreciation, ${ }^{220}$ and the 1712 law was followed by successive acts until $1741 .^{221}$ Figure 2 shows they were mistaken. In a context of steadily depreciating currency as shown in Figure 2, debtors benefit by delaying repayment as long as possible. Although creditors advocated remedial legislation against the nominalist approach, there arose popular protest against the proposition of paying more than the nominal amount agreed upon, and the General Court never succeeded in passing (or never chose to pass) legislation protecting creditors until $1742 .{ }^{222}$ The result was that many debtors defaulted on their debts, knowing that, by the time a damage award was imposed against them, the debt would decrease in value. William Douglass observed in a 1740 pamphlet: "People run in Debt, endeavour after a long Credit, and refuse paying their Debts when due; because while Bills are continually depreciating, the longer the Debt is outstanding, they pay their Creditors with a less and less Value, than was contracted for." ${ }^{223}$ Creditors, as a consequence, had to file suit to collect the debt.

There were also times, however, when currency scarcity led to increased litigation of a different sort. When money was so scarce that there was widespread reversion to barter exchanges, there were unusually high default rates, as debtors became unable to repay their debts because of the lack of money. The years from 1720 to 1721 were a time of particular monetary scarcity in New England. ${ }^{224}$ In 1721 , for example, a pamphlet by

219. Supra note 173 and accompanying text.

220. FELT, supra note 200, at 64 (citing Massachusetts Provincial Records of November 1712).

221. Id. at 100. On the 1742 change in policy, see infra text accompanying notes 306-309.

222. FELT, supra note 200, at 101.

223. DOUGLASS, supra note 172, reprinted in 3 COLONIAL CURRENCY REPRINTS, supra note 20 , at 336 .

224. In 1720, for example, an anonymous pamphlet deplored "the distressing Circumstances we are fallen into" because of a "want of a sufficient Medium to carry on the Trade."

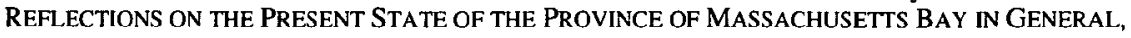
AND TOWN OF BOSTON IN PARTICULAR RELATING TO BILlS OF CREDIT AND THE SUPPORT OF 
John Wise, a private currency advocate, described how scarcity of currency led to reversion to barter and general economic stagnation.

As for the Money Medium we have none at all, its quite Exhausted; and the Bills which have supplyed its Place, they are grown very scarce, which is evident by the Loud Complaints of Town and Country....

... [T] o Exchange all sorts of Commodities without a suitable Medium will destroy Trade, and render it impracticable, as to any great Good, or Clear Profit that will insue upon it to such a People. For that the Inconveniencies that will attend a Common Barter without a Medium are innumerable and intollerable. ${ }^{225}$

The chronic lack of currency and steady depreciation led to further efforts to issue currencies through private banks, all of which were suppressed by the government. John Colman, for example, gained notoriety advocating his land bank proposal again during this time. In 1720, he wrote a pamphlet criticizing the government's currency policies, which led to his arrest and trial for disturbing the peace. ${ }^{226}$ Colman believed that the lack of currency was creating unacceptable hardship throughout the colony. According to Colman's pamphlet,

The Medium of Exchange, the only thing which gives life to Business, Employs the Poor, Feeds the Hungry, and Cloaths the Naked, is so Exhausted; that in a little time we shall not have wherewith to Buy our Daily Bread, much less to pay our Debts or Taxes. ${ }^{227}$

Colman emphasized the preponderance of lawsuits instituted during times of currency hardship. Colman's focus was not the harm to creditors caused by currency depreciation, but rather the prevalence of lawsuits that operate unfairly on debtors in an environment of currency shortage. According to Colman, currency scarcity leads to lawsuits because people are no longer able to pay their debts or liquidate their assets at fair prices. Creditors, typically facing similar problems themselves, attempt to claim what money

TRADE BY THEM, reprinted in 2 COLONIAL CURRENCY REPRINTS, supra note 20, at 44 . According to this pamphlet, economic problems increased because, "since the Invention of Money, that method [barter] has been much laid aside; and Money has been Universally Received \& Improved as the ... Medium for carrying on of Trade, between Persons \& Countries." Id. at 48.

225. A WORD OF COMFORT, supra note 214, reprinted in 2 COLONIAL CURRENCY REPRINTS, supra note 20, at 165-66.

226. Billias, supra note 203, at 5-6. See generally 1 DAvis, supra note 150 , at 66-69 (discussing the advocacy of private banks in the 1720s).

227. John COlman, THE Distressed State of the TOWN OF Boston Considered (Boston, Nicholas Boone, Benjamin Gray \& John Edwards 1720), reprinted in 1 COLONIAL CURRENCY REPRINTS, supra note 20, at 397, 398. 
they can. Colman also protested the fines collected by judges and lawyers, which he calls a "dead loss" to the society. According to Colman:

We find already the miserable Effects of the want of a Medium in these Instances; besides a Torrent of other mischiefs breaking in upon us, viz.

The vast Number of Law Suits occasioned thereby, the Courts are open, and every Term, four or five hundred Writs (and perhaps more) given out against good honest Housekeepers, who are as willing to pay their Debts as their Creditors would be, and have wherewith to Pay, but can't Raise Money, unless they will Sell their Houses at half Value, which they have been Working hard for, it may be these Twenty years, and so turn their Families into the Streets; and this because they are obliged to Work for half, nay, some for two thirds Goods, and their Creditors will take nothing but Money; and so they are Squeezed and Oppress'd, to Maintain a few Lawyers, and other Officers of the Courts, who grow Rich on the Ruins of their Neighbours, while great part of the Town can hardly get Bread to satisfie Nature; Nay, to my astonishment, I am informed, that there a thousand Writs made out to this April Court, in this one County, which is a scandal to the Land, to have it spoken. And then, I am perswaded that the Charges of the Courts in this County is Six Thousand Pounds per Annum; and this pays no Debt, but is a dead Loss to People, and brings them farther in Debt, and makes them the less able to support either Church or State. ${ }^{228}$

Other commentators emphasized that currency scarcity provides opportunities for creditors to abuse debtors:

Among the innumerable exorbitant Mischiefs which arise from the want of some proper Medium of Exchange, ... [is] a Multiplicity of Law-Suits, to the enriching a few luxuriant Cut-throats, and reducing many honest, frugal, industrious Familys to Beggary, and many more to the very precipice of Ruin, unless speedy Relief intervene. ${ }^{229}$

The next Section looks at the currency history of Massachusetts during the period from 1726 to 1751 in more detail. 


\section{B. The Currency Crises of the 1720s and 1730s and Their Resolution}

As shown in Figure 2, Massachusetts's currency steadily depreciated after 1720. Historical accounts suggest that, although economic conditions were poor throughout, there were three distinct currency "crises," in each of which citizens were forced to resort to barter: 1726 to 1727,1733 to 1734 , and, in particular, the period from 1738 to 1741 . This Section reviews that history. ${ }^{230}$ The subsequent Part shows the effects of these currency crises on litigation in Plymouth County, Massachusetts.

In 1726, a credit crisis in England propelled English creditors to pressure New England merchants to pay all overdue accounts. ${ }^{231}$ The New England merchants with debts to England, in turn, pressured their debtors to pay outstanding debts and thereby increased the general demand for bills of credit. The currency shortage was exacerbated by the fact that a substantial portion of a $£ 100,000$ issue of 1716 that was circulated by means of loans to individuals became due in May of $1727 .{ }^{232}$ Currency scarcity became so extreme that the Massachusetts General Court authorized payment of taxes in commodity money on a colony-wide basis in 1727 . Colonial citizens were permitted to pay in any of twenty-three types of goods. ${ }^{233}$

To remedy the currency shortage, the colonial assembly adopted a lenient approach toward redeeming outstanding currency issues and authorized further issues in large volumes. The assembly, for example, failed to require total redemption of the bills loaned out in $1716 .{ }^{234}$ Then, in 1728 , the government issued $£ 60,000$ in bills of credit, circulated by means of loans through the town loan offices, as well as $£ 48,000$ in bills to cover government operational expenses and salaries. ${ }^{235}$ Despite the severe currency scarcity of just a year before, leaving the 1716 bills outstanding and issuing new bills in 1728 caused a depreciation of the currency. Creditors, perhaps for the first time, began to fear intensely that currency depreciation would allow debtors to pay less in real terms than they had contracted to pay. The depreciation of the currency also meant that court fees were reduced in real terms. Reduced court fees gave debtors a greater incentive to delay payment and to allow creditors to sue and obtain a judgment against them before paying their debts.

230. I am grateful to Ronald Michener for his comments and suggestions relating to the chronology presented in this Section.

231. Joseph A. Emst, "The Labourers Have Been the Greatest Sufferers"; The Truck System in Early Eighteenth-Century Massachusetts, in MERCHANT CREDIT AND LABOUR STRATEGIES IN HistoRICAL PERSPECTIVE 16, 19 (Rosemary E. Ommer ed., 1990).

232. I DAVIS, supra note 150 , at 107 . As of 1726 , there was $£ 358,140$ total in Massachusetts bills of credit in circulation. BROCK, supra note 14, at 591 tbl.2.

233. 1 DAVIS, supra note 150, at 108.

234. Id. at 107 .

235. Id. at 106 . 
Then in 1730, Jonathan Belcher ${ }^{236}$ was appointed Governor of Massachusetts with directions to reform Massachusetts's currency for the benefit of English creditors. The English Board of Trade almost immediately sent him a Royal Instruction to retire all bills of credit in the colony over an eleven-year period. All bills of credit currently circulating were to "be called in and sunk according to the periods and provisions of the respective acts by which they were issued." ${ }^{237}$ No more than $£ 30,000$ in bills were to be issued in any year, and no bills were to remain outstanding after $1741{ }^{238}$ After 1741, Massachusetts was to return to the use of gold and silver coins. The Instructions also required that every act passed by the assembly authorizing the issuance of any bills of credit beyond $£ 30,000$ include a suspending clause. ${ }^{239}$ Suspending clauses "suspended" the operation of an act until it received approval and confirmation in England, in this case, by the Board of Trade.

The 1730 Instruction represented a radical change in policy. To comply with the Instruction would have required the Massachusetts government to tax its entire money supply out of circulation over the eleven-year period. In $1730, £ 335,323$ in bills of credit was circulating within the colony, ${ }^{240}$ and the government was consistently issuing more than $£ 30,000$ per year to pay operational expenses. Thus, the Instruction imagined a $£ 300,000$ tax along with a permanent budget cut.

The Board of Trade had merely advisory powers in the colonies, and its Instructions were routinely ignored. ${ }^{241}$ The Board did, however, have the power to threaten governors with dismissal. Belcher, therefore, was under pressure to implement the Board's policies, and he vehemently urged the House of Representatives in this direction. Although the extent to which the Instructions would be honored was unclear, their tenor and dimension created great uncertainty in Massachusetts.

Initially, it was widely believed that they would be strictly enforced. According to the author of an anonymous pamphlet:

236. Jonathan Belcher was bom in Massachusetts, graduated from Harvard in 1699, and had a long political career in the colony. He won election to the Council in 1718 and sat again in 1722, 1723, and 1726. He served as the Massachusetts special agent in London from 1728 to 1730 , where he developed a belief in the importance of stabilizing the value of the colonial bills of credit. ROBERT ZEMSKY, MERCHANTS, FARMERS, AND RIVER GODS: AN ESSAY ON EIGHTEENTH-CENTURY AMERICAN POLITICS 102-03 (1971).

237. Call in Certain Bills of Credit (1730), reprinted in 1 LABAREE, supra note 55, at 220. See generally I DAVIS, supra note 150 , at $111-51$ (describing the Royal Instructions and subsequent attempts to enforce their provisions in the period from 1730 to 1741).

238. Massachusetts Restricted to $£ 30,000$ Currency (1730), reprinted in I LABAREE, supra note 55 , at $220-21$.

239. See id. at 221.

240. BROCK, supra note 14 , at 591 tbl.2.

241. EDMUND S. MORGAN, THE BIRTH OF THE REPUBLIC, 1763-89, at 11 (3d ed. 1992). 
[The Instructions] seem'd to afford a promising Prospect, among other Regulations of the Bills, that the great Quantity of 'em then outstanding beyond their stated Periods would be soon drawn in, and those Bills, whose Periods were not yet arriv'd, would be duly call'd in and sunk upon their Arrival; and that now an End would be put to the several Mischiefs, which had been occasion'd by the late Law, which made the Bills a Tender . ... ${ }^{242}$

The Board of Trade and Governor aside, however, Representatives felt an opposite pressure to allow more bills to remain outstanding. Indeed, the immediate effect of the Instructions was to initiate a prolonged battle between the colonial assembly and the Governor over the extent to which they should be enforced. ${ }^{243}$ The assembly petitioned the Privy Council in England in 1731, and again in 1732, for retraction of the Instructions, and introduced supply bills (resembling a budget) requiring more than $£ 30,000$ in new bills of credit to be issued. ${ }^{244}$ The Governor, meanwhile, continued to insist that the Instructions be followed. These political battles led to a perplexing result: For almost three years the treasury was shut down and there were few new currency issues. More specifically, in the three years after Belcher's arrival, only $£ 19,000$ in bills of credit were issued for general expenses, and $£ 13,900$ to pay the salaries of the Governor and assembly members. ${ }^{245}$

The assembly, however, had control over appropriations and refused to retire many of the outstanding bills of credit through taxation. According to Hutchinson, instead of taxing or redeeming the bills according to dates established at issuance, the House "suffered one year after another to pass with light taxes and laid heavy burdens upon distant years...." ${ }^{246}$ Not redeeming the bills of credit according to the schedule established when they were issued immediately lowered their value. It also reduced the value of all other bills of credit in circulation because it generated uncertainty as to whether the government would retire bills on schedule in the future. The failure of the government in 1731,1732 , and 1733 to issue substantial quantities of new bills, combined with the decision to leave in circulation

242. ENQUIRY, supra note 190 , reprinted in 4 COLONIAL CURRENCY REPRINTS, supra note 20 , at 160 .

243. These tensions are discussed in 1 DAVIS, supra note 150 , at 116-21.

244. Id. at 115-17.

245. Id. at 116.

246. 2 HUTCHINSON, supra note 154, at 287 . Hutchinson explained the context of the 1733 monetary problems as follows:

In 1733 there was a general complaint throughout the four governments of NewEngland of the unusual scarcity of money. There was as large a sum current in bills of credit as ever, but the bills having depreciated they answered the purposes of money to much less in proportion. The Massachusetts and New-Hampshire [govemments] were clogged with royal instructions.

Id. at 288-89. 
bills scheduled to be retired, led to severe currency scarcity and tightened credit conditions ${ }^{247}$ as well as severe currency depreciation ${ }^{248}$ in 1733 and in the beginning of 1734 .

Adherence to the Royal Instructions, however, became even more complicated by problems caused by Rhode Island's currency policies. Because Rhode Island was not subject to similar Instructions, it was able to issue bills of credit far beyond its need. ${ }^{249}$ Rhode Island bills flooded into Massachusetts. ${ }^{250}$ Many in Massachusetts argued that enforcement of the Instructions would simply cause greater reliance on Rhode Island bills and have no positive effect on Massachusetts's currency. Indeed, many believed that the Instructions were causing Massachusetts residents to subsidize Rhode Island's spending: Rhode Island's government used its bills of credit to finance its operations and to loan to its residents, but the diffusion of the bills throughout New England externalized the costs of Rhode Island's currency depreciation. In addition, Rhode Island's currency expansion allowed its residents to lend money to Massachusetts residents at a profit. According to an anonymous 1736 pamphlet, "the Interest of their [Rhode Island's] Money out on Loan pays the whole Charge of the Government,

247. Samuel Mather's 1734 letter to the Weekly Journal, for example, explained that currency scarcity led initially to an increase in credit agreements, but that sustained scarcity led to default on those agreements. According to Mather,

Every one knows that Money is necessary for the carrying on of Trade: And common Experience has convinced us of this Government that where Money fails we cannot well buy. T'is true Credit may supply the Defect of it to some small Degree for a little while. But what is Credit? It is only the Expectation of Money within some certain limited time: If therefore the Money is not to be had at the end of the term prefixed, What must become of the Credit? It must necessarily and inevitably sink: Nor will ever so many Acts at all avail to Support it.

[Samuel Mather], To the Publisher of the Weekly Journal (Feb. 4, 1734), reprinted in 3 COLONIAL CURRENCY REPRINTS, supra note 20, at 21, 21-22.

248. Mather's letter also deplored the depreciating state of Massachusetts currency resulting from the Government's failure to call in the bills of credit according to schedule:

The fatal Effects of the Depreciation of our present nominal Money... are many: These are some of them, that the Prices of Things are by means of this at the utmost Disorder \& Confusion; that the Landlord and Creditor are defrauded of what they contracted for and is their just Due, because their Tenants and Debtors Pay considerably less Silver than what was at the time of Bargaining agreed for; that many Widow's and Orphans, whose Revenues were competent and equal to their Support, can now scarcely subsist with them; that the poor Country Ministers have not the Salaries which by Contract is their Due; that the Day Labourer has not his full Wages; and, in fine, that many Officers in the Service of the Government have scanty and miserable Allowances in Comparison with what they had formerly: These are a few of the innumerable Mischiefs, which have fallen out in this Government thro' the Want of a good Regulation and an invariable Establishment of Money; Or, in one Word, because we have no lawful Money among us.

Id. at 24-25. Many pamphlets from this time refer to the harm that depreciating currency caused to those on salary, such as government officials, ministers and widows, who survived on fixed-sum estates. See I DAVIS, supra note 150, at 91-95.

249. I DAVIS, supra note 150 , at 123.

250. See 2 HutChINSON, supra note 154, at 289. 
while we [Massachusetts] are loaded with Taxes." 251 According to Hutchinson, the influx of Rhode Island bills meant that, even though Massachusetts residents were paying back their "debts" each year that bills were recalled, they still could not import any more silver to use in trade with the British. ${ }^{252}$

The currency uncertainty increased when, in 1733, a group of prominent merchants in Massachusetts formed a bank and issued $£ 110,000$ in promissory notes redeemable over a ten-year period in silver at a fixed rate of nineteen shillings per ounce. ${ }^{253}$ The bank's founders hoped that the notes, called "Merchant's Notes," would provide an alternative to Rhode Island's bills ${ }^{254}$ and "prevent the Oppression which almost ever accompanies a Trade by Barter," ${ }^{255}$ which they feared would be the result of the current impass at the treasury, and of future compliance with the Instructions. The Merchant's Notes did not, however, stabilize the Massachusetts money supply. Because they were redeemable in silver at a fixed rate, they were hoarded as a protection against inflation, and Massachusetts notes were dumped by Merchant's Note holders. ${ }^{256}$

Then, according to Hutchinson, "[a]bout the same time" as the issuance of the Merchant's Notes, the impass at the Treasury was resolved. Belcher and the colonial assembly authorized the issuance of bills of credit to pay the general operational expenses from the years 1731, 1732, and 1733 at one time. ${ }^{257}$ The combined effect of the government's failure to retire bills of credit on schedule, the influx of Rhode Island bills, the increases in the money supply attributable to the Merchant's Notes, and the new issue of three years of government debts, was to begin a cycle of steadily increasing depreciation. According to Hutchinson, "every creditor was defrauded of about one third of his just dues." 258

As shown in Figure 2, the problem of depreciation became worse after 1735. In 1736, Thomas Hutchinson deemed this depreciation close to theft; all people on salary and all who had entered contracts were losing money,

251. The Melancholy State of This Province Considered, in a LetTer, from a GENTLEMAN IN BOSTON TO HIS FRIEND IN THE COUNTRY (n.p. 1736) [hereinafter THE MELANCHOLY STATE], reprinted in 3 COLONIAL CURRENCY REPRINTS, supra note 20, at 135 , 145.

252. 2 HUTCHINSON, supra note 154, at 289.

253. See NASH, supra note 203, at 138.

254. The group agreed not to use Rhode Island bills or accept them in payment, although the agreement was breached within a short time. See 2 HuTCHINSON, supra note 154, at 289.

255. To the Author of the Weekly Rehearsal, supra note 214, reprinted in 3 COLONIAL CURRENCY REPRINTS, supra note 20, at 67; see also Extract of a Letter to a Gentleman in a Neighboring Government, Concerning the New Notes of Hand (Jan. 14, 1734), in 3 COLONIAL CURRENCY REPRINTS, supra note 20, at 3, 3-15 (describing the reasoning behind the Merchant's Notes).

256. See NASH, supra note 203, at 139.

257. 2 HUTCHINSON, supra note 154, at 289.

258. Id. 
particularly because of the government's lack of an effective response to the problem of Rhode Island bills. Hutchinson argued that "every Person who has debts out of a long standing, has lost more by the falling of the Money, than the ordinary profits in Trade will countervail." According to Hutchinson:

[T] he Government is the Guarantee that all just \& legal Contracts shall be perform'd; but with us they are daily broken, \& necessarily will be so, whilst our Money continues in its present fluctuating Circumstances. $^{259}$

The most serious currency crisis of the first half of the eighteenth century, however, occurred during the period from 1738 to 1741 . In 1737, Governor Belcher was reprimanded by the Board of Trade for assenting to three acts within the space of seven months that authorized the reissuance of more than $£ 106,000$ in bills of credit that were to have been retired. ${ }^{260}$ Belcher was informed that his position as Governor was at risk if he failed to comply with Instructions to recall the bills. ${ }^{261}$ The Board of Trade also insisted again that every act authorizing currency issues beyond $£ 30,000$ include a suspending clause, to ensure that the Board would be able to deny approval for all large currency issues. ${ }^{262}$ This reprimand marks a turning point: The Board of Trade made it clear that it would demand compliance with what was now a 1742 deadline to redeem all outstanding bills. This meant that between 1738 and 1742 over $£ 200,000$ in bills would have to be retired through taxation. ${ }^{263}$

Still pressured by the assembly, Belcher's solution was to limit the issues of bills of credit to $£ 30,000$ a year, but to increase the value of the bills in real terms. In 1737 and 1738, the government issued what were named "New Tenour" bills. They were of higher value than the "old tenour" bills because the government promised to redeem them in gold and silver in $1742 .{ }^{264}$ The purpose of the New Tenour bills was to create a more stable circulating medium. The government, however, mistakenly undervalued them in relation to gold and silver and they were immediately

259. A LETTER to a MEMBER OF THE HONOURABLE HOUSE OF REPRESENTATIVES, ON THE PRESENT STATE OF THE BILls OF CREDIT (Boston, n.p. 1736), in 3 Colonial CuRrency REPRINTS, supra note 20 , at $150,160-61$.

260. See Observe Instructions Restricting Bills of Credit (1737), reprinted in I LABAREE, supra note 55 , at $221-22$.

261. Id. at 222 .

262. Id.

263. ZEMSKY, supra note 236, at 115.

264. Letter from William Shirley to the Lords of Trade (Jan. 24, 1742), in 1 CORRESPONDENCE OF WILLIAM SHIRLEY, GOVERNOR OF MASSACHUSETTS AND MILITARY COMMANDER IN AMERICA, 1731-1760, at 95-96 (Charles Henry Lincoln ed., AMS Press 1973) (1912). 
hoarded. William Shirley, who replaced Belcher as Governor of Massachusetts in 1741, later informed the Lords of Trade:

These Bills, which were the only Bills of Credit in the province redeemable with Silver and Gold, were at the very time of their Emission depreciated above $33 \mathrm{P}$ Cent. both in publick and private payments by means of some Mistakes in the before mentioned Acts ... insomuch that before the end of the year 1739 private persons began to hoard 'em up for the Advantage of exchanging 'em at the Treasury, after December $1742 \ldots{ }^{265}$

In 1738 , the economic "crisis" caused by the changes in the currency policies began. Bills of credit began to be retired through taxation in large quantities. This heavy taxation continued for the next four years. Hutchinson commented that "the last year, 1741, had more laid upon it than any of the four or five preceding years... and... it was deemed an insupportable burden." 266 The New Tenour bills were "hoarded up" and out of general use. Reversion to barter became inescapable. ${ }^{267}$

Even the influx of Rhode Island bills appears to have been inadequate. According to one commentator: "But so great is the Want of Money among us, that as bad as these Rhode-Island Bills are, [those who have outstanding bonds in Massachusetts Bills], would gladly accept these Rhode-Island Bills in Lieu of them, but can't get their Pay in any Sort of Bills." ${ }^{268}$ A second account, however, suggests that the bills of credit in circulation did not solve the currency problem because they were so depreciated and their value so unstable. William Douglass, a physician and a prominent antipaper-money polemicist, wrote in 1738 :

The principal Design of a Currency or Medium of Trade, is to avoid the Inconveniencies of Barter: Paper Currency in large Quantities does not answer this End; because of its Fluctuation, or rather progressive less Value; which obliges the Merchant at length to return to Barter again, as being safe and better. ${ }^{269}$

265. Id.

266. 2 HUTCHINSON, supra note 154 , at 287.

267. See, e.g., RICHARD FRY, A SCHEME FOR A PAPER CURRENCY (n.p. 1739), in 3 COLONIAL CURRENCY REPRINTS, supra note 20, at 255, 255-56; A LETTER FROM A COUNTRY GENTLEMAN AT BOSTON TO HIS FRIENDS IN THE COUNTRY (n.p. 1740), reprinted in 4 COLONIAL CURRENCY REPRINTS, supra note 20, at 27, 30; A LETTER RELATING TO A MEDIUM OF TRADE (Boston, New Printing-Office 1739), reprinted in 4 COLONIAL CURRENCY REPRINTS, supra note 20 , at 3, 4-5.

268. A Proposal To Supply the Trade with a Medium of Exchange (Boston, n.p. 1737) [hereinafter A PROPOSAL], reprinted in 3 COLONIAL CURRENCY REPRINTS, supra note 20, at 163,171 .

269. [William douglas], AN ESSAy CONCERNing Silver and PaPer CuRRENCIES, MORE ESPECIALLY WITH REGARD TO THE BRITISH COLONIES IN NEW-ENGLAND (Boston, S. 
There is voluminous evidence of the scarcity of money in this period. Laborers complained of being paid solely in "shop notes," limiting their expenditures to a particular shop, and a narrow set of goods. ${ }^{270}$ Even creditors and employers complained about "truck" practices. According to a 1740 pamphlet:

[T]he most laborious and industrious among us... have been greatly distressed by Means of the Want of a Sufficiency of Bills: by having their Debts postponed; by being obliged to take Goods (and in a much greater Degree of Quantity and Fineness than their Inclinations or Circumstances required) in lieu of Bills ... and in fine, by being put under a Necessity of pursuing a despicable Trucking (and naturally a cheating) Trade. ${ }^{271}$

In 1739, the House of Representatives approved Boxford's constable's plea that the town be allowed to accept certificates for hemp and flax as taxation in place of money. ${ }^{272}$ W.T. Baxter's examination of the Hancock family's business papers also reveals the extent to which the currency crisis affected businesses in Boston. In 1740, Thomas Hancock wrote, "[I]f I can raise Cash, which name is almost unknown among us, Such Times New England never see before, for years past I could Sooner raise $£ 500$ or $£ 1000$ at a pinch than $£ 100$ now ...." ${ }^{273}$ According to the Hancock records, the economic crisis beginning in 1737 decreased demand for trade goods in the colonies, leading to stagnation in English trade and making credit difficult to obtain. ${ }^{274}$

Colonial citizens also complained that currency scarcity led to further debt litigation. According to a 1739 letter addressed to the General Court by . Richard Fry, who was then serving a prison sentence for debt, the colony needed

Kneeland \& T. Green 1738), reprinted in 3 COLONIAL CURRENCY REPRINTS, supra note 20, at $217,225-26$.

270. See 1 DAVIS, supra note 150, at 93-95; see also Ernst, supra note 231, passim (describing how the history of the movement protesting the "truck" system-payments to wage laborers in credit, such as in shop notes-related to the "currency question" throughout the first half of the eighteenth century). Emst describes how wage laborers were particularly interested in the currency question because currency scarcity often meant that they would be paid in shop notes. This practice was condemned as unfair to laborers, and as requiring excessive purchase of goods imported from England.

271. AN INQUIRY INTO THE NatURE AND USES OF Money (Boston, S. Kneeland \& T. Green 1740), reprinted in 3 COLONIAL CURRENCY REPRINTS, supra note 20, at 365, 387.

272. 17 JOURNALS OF THE HOUSE OF REPRESENTATIVES OF MASSACHUSETTS, 1739-1740, at 200 (Mass. Historical Soc'y 1940).

273. BAXTER, supra note 69, at 79 (quoting Thomas Hancock's Letter Book entry for Aug. 2, 1740).

274. See id. at $45-75$. 
[r]elief under their present difficult and distressing Circumstances, for want of a sufficient Medium; whereby the Trade and Business of the Town is very much decayed, Law-Suits increased, and Cash to purchase the Necessaries of life hard to be attained, even by many of good Estates among them. ${ }^{275}$

In the 1739 and 1740 House of Representatives sessions, House members appealed to the Governor that, because the " $[b]$ urthen already laid on this and the two succeeding Years, are equal if not beyond the People's Ability," calling in the bills according to the Instructions would "bring on the greatest Oppression on Multitudes, Stagnation of our Trade, and the terrible Consequences of publick Confusion." People were "groaning under heavy Burthens and distressing Difficulties." ${ }^{276}$ Fears of economic distress grew with the approach of 1742 , when all outstanding bills were to be recalled. The journals of the House of Representatives show that House members were extremely concerned about the problems their constituents faced. Trade increasingly occurred through barter. The currency that existed was of low value. To comply with the Royal Instructions, the tax burden would have to increase each year until 1742. There was a growing resentment about the requirement that the Board of Trade give prior approval for new currency issues. Representatives took action and began accepting proposals for currency reform. In June 1739, it was argued in the House that

there is a great scarcity of Bills of Credit, which are the only Medium of Commerce among us, and in as much as those Bills only which may be issued for the necessary Support of His Majesty's Government here, can by no Means be a sufficient Supply for carrying on the Trade and Business of this Province, which must therefore be brought under great Declensions unless some further Expedient can be found. ${ }^{277}$

The House voted to accept "any Scheme or Proposals from any Persons whomsoever for the furnishing a further Medium of Trade, in such Way and Manner as that the Value thereof may be maintained." 278

The vote to solicit proposals for new currencies deepened tensions between the Representatives and the Governor. The Governor insisted that "His Majesty has given this Instruction, in his Royal Grace and Wisdom, from a real Regard to the true Welfare and Prosperity of His good Subjects

275. FRY, supra note 267 , at $255-56$ (emphasis added).

276. 17 JOURNALS OF THE HOUSE OF REPRESENTATIVES, 1739-1740, supra note 272, at 12526.

277. Id. at 79 .

278. Id. 
of this Province" and that advocacy to ignore the Instructions "is owing to a desire of keeping out a great quantity of Paper Currency, rather than to the Disabilities of the People." ${ }^{279}$ House members responded by arguing that the Instructions directly violated Massachusetts's Charter, which permitted the government to determine its own public finance policies. According to a letter presented by the House to the Board of Trade,

besides this inextricable Difficulty as to paying their Debts, arising by this Instruction, it also ... seems contrary to that Power given them by the Royal Charter, to make such Laws in the raising Money, and Ways and Means for the discharging the publick Debts, as the General Court shall think from time to time to be for the Good and Welfare of this your Majesty's Province, and the People inhabiting the same. ${ }^{280}$

Tensions escalated when two proposals were presented to the House to establish private banks that would issue bills of credit to replace the Massachusetts currency. A proposal for a Land Bank was endorsed by 395 people from sixty-four towns around the colony. ${ }^{281}$ The proposal sought to issue $£ 150,000$ in New Tenour values, secured by land mortgages and personal property. A set of mostly wealthy Boston merchants proposed a "Silver Bank," which would issue $£ 120,000$, redeemable in silver after fifteen years. ${ }^{282}$ Neither plan received government approval. Nevertheless, both schemes were put into effect in 1740 and began issuing bills. ${ }^{283}$

The Land Bank and the Silver Bank became the focus of political controversy in Massachusetts. ${ }^{284}$ Generally speaking, merchants supported the Silver Bank and vehemently opposed the Land Bank. ${ }^{285}$ The Land Bank had tremendous popular support and was viewed as a legitimate remedy to an urgent problem. ${ }^{286}$ Threatened by the Board of Trade and pressured by English and New England merchants, Belcher exercised his authority as

279. Id. at $149-50$.

280. Id. at 151 .

281. Billias, supra note 203, at 9.

282. Id. at 10 .

283. Id. at $12-13$.

284. It is beyond the scope of this Article to describe the histories of the Land and Silver Banks in detail. For information on the Banks, see JOHN L. BROOKE, THE HEART OF THE COMMONWEALTH: SOCIETY AND POLITICAL CULTURE IN WORCESTER COUNTY, MASSACHUSETTS, 1713-1861, at 55-128 (1989); 2 DAVIS, supra note 150, at 130-67; NASH, supra note 203, at 212-16; Billias, supra note 203, passim; and Andrew McFarland Davis, Provincial Banks: Land and Silver (1895), reprinted in 3 PUBLICATIONS OF THE COLONIAL SOCIETY OF MASSACHUSETTS 2-40 (1900). For Thomas Hutchinson's critique of the Land Bank, see 2 HUTCHINSON, supra note 154, at 298-308. For more detailed discussion of the political repercussions of the Land Bank controversy, see Billias, supra note 203, at 32-42.

285. Davis, supra note 284 , at 15-16, 22-24. The debate over the Land Bank can be followed in the pages of the Boston News-Letter during the summer and autumn of 1740 and the early issues of 1741 .

286. Billias, supra note 203 , at 15 . 
Governor by taking action against government officials who supported the Land Bank. On November 5 and 6, 1740, he issued proclamations stating that any government official or military officer who received or passed a Land Bank bill or gave encouragement to the Land Bank would be dismissed from office. ${ }^{287}$ In response, in November and December of 1740, Samuel Adams, Sr. (father of the famous revolutionary), William Stoddard, Robert Hale, and John Choate resigned from their positions as Justices of the Peace and were officially dismissed by Belcher. ${ }^{288}$ Nine Massachusetts military officers resigned voluntarily on December $29,1740 .{ }^{289}$ By January 3, 1741, Belcher had dismissed seven other Justices of the Peace for receiving and passing Land Bank bills. ${ }^{290}$ Going further, the Governor ordered military officials to investigate whether their subordinates were involved with the Bank and required Justices of the Peace to prevent the use of Land Bank bills as judicial remedies. ${ }^{291}$ On January 27, 1741, the Governor and Legislative Council extended the prohibition on use of Land Bank bills to all lawyers. ${ }^{292}$

Meanwhile, the number of subscribers to the Land Bank grew to $920,{ }^{293}$ Land Bank bills went into general circulation, and many towns agreed to accept Land Bank bills in payment of taxes. ${ }^{294}$ Despite the Governor's efforts, in 1741 Land Bank supporters picked up seats on local boards of selectmen throughout Massachusetts ${ }^{295}$ and gained a majority of both the Massachusetts House of Representatives and the Assembly. ${ }^{296}$

287. Davis, supra notc 284 , at 19.

288. See PaPERS AND ReCORDS RELATING TO THE LAND Bank OF 1740, IN THE MASSACHUSETTS ARCHIVES AND SUFFOLK COURT FILES, in 4 PUBliCATIONS OF THE COLONIAL SOCIETY OF MASSACHUSETTS, supra note 284, at 1 (providing dates of resignations and dismissals of Massachusetts's Justices of the Peace in connection with the Land Bank affairs); Davis, supra note 284 , at 19-22 (describing the resignations and dismissals of the Justices of the Peace favoring the Land Bank).

289. Davis, supra note 284, at 20.

290. See id. at 19-20.

291. Id. at $20-21$.

292. The Governor's proclamation reads:

Voted, That no person shall be admitted to appear and plead before this Board as an attorney and counsellor at law, on any pretence whatever, who shall pass, receive, or give encouragement to the bills called the Land Bank or Manufactory Bills ....

Id. at 22 .

293. 2 DAVIS, supra note 150, at 292-93; see also id. at 295-313 (listing the names of all Land Bank partners).

294. See BROOKE, supra note 284 , at 61 (describing how, in 1741 , Mendon, Hardwick, Brookfield, and Leicester agreed to accept Land Bank bills for town charges).

295. Id. at 61-62 (describing how Land Bankers were elected to seats in town governments in 1741 but "rarely retained a dominant position in subsequent years").

296. According to Thomas Hutchinson, "by far the majority of the representatives for 1740 were subscribers to or favorers of the [land bank] scheme, and they have since been distinguished by the name of the land bank house." 2 HUTCHINSON, supra note 154, at 300; see Davis, supra note 284, at 23-26 (discussing the success of several Land Bank proposals in various representative bodies). 
On March 27, 1741, however, Parliament dealt a legislative blow to the Land Bank by applying the Bubble Act of 1720 to the colonies. ${ }^{297}$ The Bubble Act had been enacted to prevent speculative financial ventures in England by prohibiting joint-stock ventures. Most contemporaries believed that the Act's provisions were not applicable to the Land Bank, because it was not strictly a joint-stock company. ${ }^{298}$ Nonetheless, Parliament's extension of the Bubble Act to the colonies gave the opponents of the Land Bank sufficient legal support to suppress the Bank.

Parliament's extension of the Bubble Act provided legal justification for Belcher's earlier repressive measures. In August 1741, however, he was replaced by William Shirley, a longstanding Massachusetts resident and a respected politician. ${ }^{299}$ Shirley took a more sympathetic approach towards the Land Bank. He restored many subscribers to their public offices and accepted their nominations to the Council. ${ }^{300}$ Parliament meanwhile sought to suppress the Land Bank more directly. Parliament ordered Shirley to enforce the provisions of the Bubble Act that required redemption of outstanding Land Bank bills at full value. This order proved devastating to Land Bank subscribers. Land Bank bills had been sold at a fifty-percent discount. The holders of the bills sought to redeem them at heavy costs to subscribers. ${ }^{301}$ Samuel Adams, Sr., for example, lost much of his estate as a consequence.

The Land Bank episode led to growing distrust and hostility towards British policies. ${ }^{302}$ Indeed, there are strong links between the Land Bank crisis and the American Revolution. Sam Adams's career as a

297. Billias, supra note 203, at 15; Davis, supra note 284 , at 26-29.

298. Historians have interpreted the Bubble Act as inapplicable to the colonies, making it irrelevant to the legality of the Land Bank. According to Billias, "[t]he Land Bank could hardly be construed as coming under the scope of the old Bubble Act.... Moreover, in two earlier decisions the British government had made it quite clear that the issuance of paper money by private persons in the colonies was legal." Billias, supra note 203, at 15. According to Davis,

The pretence that the Bubble Act originally applied to the Colonies was more than absurd, it was wicked; and the language of the preamble of the Act of 1741 practically recognizes that fact.... More than that, the Attorney-General himself had filed an opinion which might have been quoted to show that what was then being done had been pronounced to be legal by the highest counsel in the realm.

Davis, supra note 284, at 29.

299. See Benjamin Lynde, JR., The Diaries of Benjamin Lynde and of Benjamin LYNDE JR. 114 (photo. reprint Cambridge, Riverside Press n.d.) (1880). Belcher was ultimately dismissed because he was suspected of complacency toward the Land Bank and disloyalty toward England. According to Thomas Hutchinson, Belcher's opponents deceptively portrayed him as disloyal: Belcher was dismissed after a false accusation that he failed fully to suppress the Land Bank because his brother-in-law had spoken out in favor of the Land Bank. 2 HUTCHINSON, supra note 154 , at 303.

300. Billias, supra note 203, at 37.

301. See 2 HUTCHINSON, supra note 154, at 300-02; Billias, supra note 203, at 38-40.

302. According to the historian John Schutz, "[w]hen Jonathan Belcher was recalled from the governorships of Massachusetts and New Hampshire in 1741, the provinces were nearly in revolution." John A. Schutz, Succession Politics in Massachusetts, 1730-1741, 1958 WM. \& MARY Q. 508, 508. 
revolutionary, for example, began with his resistance during the resolution of Land Bank affairs. One biographer has argued that the currency crisis led Adams to write his 1743 master's thesis at Cambridge, entitled, "Whether it be lawful to resist the Supreme Magistrate, if the Commonwealth cannot be otherwise preserved.' [Samuel Adams] fearlessly maintained the affirmative ...." ${ }^{303}$ According to Hutchinson, Sam Adams "first made himself conspicuous" upon his father's death in 1748 when the police, under order of execution, attempted to seize and to put up for public auction several buildings on his father's estate in order to repay alleged debts still outstanding from the Land Bank. Adams harassed both the auctioneers and the potential buyers of the estate with such vehemence that the auction was called off, which increased his notoriety as a staunch advocate of colonial liberties. ${ }^{304}$ As mentioned earlier, John Adams viewed the British suppression of the Land Bank as more offensive to the citizens of Massachusetts than the Stamp Act. ${ }^{305}$

As will be described in greater detail in Part IV, the monetary crisis of the period from 1738 to 1741 led to the highest levels of debt litigation in the first half of the eighteenth century. Soon after Shirley's appointment as Governor, he and the colonial assembly enacted two statutes aimed at quelling the litigation crisis. The first statute rejected the common-law nominalism doctrine by requiring all courts to adjust their judgments in accordance with an inflation schedule. ${ }^{306}$ The statute required that the schedule would be recalculated and adjusted every six months to correspond to changes in the value of outstanding currency. ${ }^{307}$ In theory, creditors would no longer suffer from depreciation of the bills of credit. According to Shirley,

Justices of his Majy's Courts in every County within the Province, who are required to proceed by them as their Rule in making up Judgments for all Debts and Dues to be contracted after the last Day of March $1742, \ldots$ and in case it shall appear by those Valuations that the Bills are depreciated since the Debt was contracted then the Judges are bound to make up Judgment for the

303. 1 William V. Wells, The Life and Public Services OF Samuel Adams $10 \& \mathrm{n}$.* (2d ed., New York, Books for Library Press 1865 ).

304. Hutchinson writes that Adams became famous for attending the public auction, where he threatened to bring an action against the sheriff and menaced any potential purchasers, thereby preventing the sale of the estate, which was viewed as advancing the cause of liberty. 3 HUTCHINSON, supra note 154, at 212; see also WELLS, supra note 303, at 25-29 (discussing the impact of the suppression of the Land Bank on Sam Adams's career as a revolutionary, and reprinting correspondence with respect to the attempt to possess Adams's father's estate).

305. Supra text accompanying note 29.

306. An Act To Ascertain the Value of Money (1742), reprinted in 3 THE ACTS AND Resolves Public and PRIVAte OF THE Province OF MASSAChuSETTS Bay, supra note 163, at 1083-85.

307. Id. at 1084 . 
true value of the Debt in Silver, or in want thereof for the nominal value of the Debt in Province Bills with an Addition of so much more in those Bills as will make the Creditor amends for the depreciating of 'em since the time of the Debts being contracted. ${ }^{308}$

The Plymouth Court Records show an adjustment of judgments to compensate for inflation beginning in May of $1742 .{ }^{309}$

The second statutory response to the litigation crisis was to increase all court fees. ${ }^{310}$ The costs of litigation, generally speaking, create a disincentive to sue and to allow oneself to be sued. The court fees in Massachusetts had been reduced in absolute terms in proportion to the depreciation of the currency. Lower court fees gave debtors a greater incentive to delay payment of their debts, and to allow creditors to obtain judgments against them, in order to benefit from depreciating currency. Increasing court fees was therefore a natural way to reduce debtors' use of legal process in this manner. ${ }^{311}$

A surprising external development, however, reduced the importance of these statutes. War broke out between France and England in the spring of 1744. Massachusetts organized and led a large-scale, and ultimately successful, attack on the French fort at Louisburgh. To encourage this attack, the Board of Trade reversed its policy regarding redemption of the Massachusetts currency. On September 9, 1744, the Board of Trade formally retracted its requirement that all acts authorizing currency issues include a suspending clause and permitted Shirley "in cases of emergencies" to give his consent "to such acts as may be necessary for the supply of the treasury ... with bills of public credit during the continuance of the present war." ${ }^{312}$ In 1744 and 1745, Massachusetts began issuing bills

308. Letter from William Shirley to the Lords of Trade (Mar. 19, 1742), in 1 CORRESPONDENCE OF WILLIAM SHIRLEY, supra note 264, at 102 (emphasis added). There have been varying accounts of how broadly and how successfully the Act was implemented. For a discussion of details pertaining to the enactment and enforcement of the Act, see 1 DAVIS, supra note 150, at 172-202. According to Thomas Hutchinson, "[T] the depreciation never had firmness enough in any instance to make the full allowance, but when silver and exchange had rose 20 per cent. or more, an addition was made of 4 or 5 only." 2 HUTCHINSON, supra note 154 , at 307.

309. 6 PLYMOUTH COURT RECORDS, supra note 77, at 312.

310. An Act for Establishing and Better Regulating Fees Within This Province (1742), reprinted in 3 THE ACTS AND Resolves PUBlC AND PRIVATE OF THE PROVINCE OF MASSACHUSETTS BAY, supra note 164, at 13-18.

311. For further discussion of colonial court fees and their impact on the timing of litigation, see Priest, supra note 24, at 2430-33.

312. Massachusetts Bills of Credit During War (1744), reprinted in I LABAREE, supra note 55, at 224. According to Hutchinson, then the Speaker of the House of Representatives, once Massachusetts began organizing its seizure of Louisburgh:

Nothing further was heard of the royal instruction against bills of credit. Such sums as the service called for and to be redeemed at such periods as the house thought proper were consented to by the governor. It soon appeared that these sums would vastly exceed what had been computed, and many declared that had a right estimate been 
of credit at a much greater rate than before to finance wartime expenditures. According to Hutchinson, two to three million pounds in bills of credit were issued during the war, and the bills "had so much depreciated that, at the end of the war, eleven or twelve hundred pounds was not equal to more than an hundred pounds sterling." 313

As described in Part IV, the volume of litigation declined dramatically once the war started. The mobilization of men for the war is one likely reason why debt litigation declined. A second reason is that the inflation was so severe that credit became unavailable. According to Hutchinson, "for some time, even for English goods, which ordinarily sell for the longest credit, no body pretended to ask credit." 314

After the war, the Massachusetts currency underwent a transformation of monumental proportions. The English government was expected to reimburse Massachusetts for its Louisburgh expedition with $£ 180,000$ English Sterling. Thomas Hutchinson, now Speaker of the House, proposed that the government use the Sterling to return to a hard-money system. ${ }^{315}$ As shown in Figure 2, and as described by Hutchinson above, by 1749, Massachusetts's bills of credit were so depreciated that between ten to eleven Massachusetts pounds equaled one pound Sterling. Hutchinson argued that by exchanging the bills at a rate of eleven to one, $£ 180,000$ Sterling would be close to sufficient to draw in all of the bills. The rest could be drawn in through a series of minor taxes. ${ }^{316}$

Many initially opposed the plan, viewing the move to hard money as a means for the wealthy to gain at the public's expense. A second opposition group, led by William Douglass, a longstanding opponent of paper money, proposed that the government repay creditors for losses they suffered over decades of depreciation by slowly increasing the value of the bills of credit, thereby forcing debtors to pay back more in value than they owed. ${ }^{317}$ Douglass's plan was extremely unpopular and, by comparison, led to support for the return to hard money. Even former Land Bank partners became supporters of the return to hard currency, in their case, because they thought that hard money after wartime depreciation would increase

made they should never have voted for the expedition, but it was now too late to go back.

2 HUTCHINSON, supra note 154, at 315.

313. 2 HUTCHINSON, supra note 154 , at 333 . For a schedule of amounts in bills of credit issued in the period from 1744 to 1748 , see 1 DAVIS, supra note 150, at 168. See also BROCK, supra 14, at 34 (characterizing this period as the "great inflation").

314. 2 HUTCHINSON, supra note 154 , at 334.

315. Id.

316. Id.

317. See id. at 335. Hutchinson's criticism of Douglass's proposal was that "the creditors and debtors would not be the same in one instance in a thousand, and where this was not the case the injury was the same, to oblige any one to pay more as to receive less than was justly due." $I d$. 
credit. ${ }^{318}$ The English government eventually paid Massachusetts $£ 183,649$ as war compensation, ${ }^{319}$ and Massachusetts returned to a hard-money system over the subsequent years. ${ }^{320}$ All debts due after March 31, 1750, were deemed "payable in coin'd silver only," at exchange rates with silver coins established by the government. ${ }^{321}$ All new debts were to be paid in silver "at six shillings and eightpence per ounce" and pieces of eight at six shillings. ${ }^{322}$

Silver and gold regained dominance. ${ }^{323}$ The English government, however, began efforts to ensure currency stability in the future. These efforts culminated in the Currency Act of 1751, which applied to all of New England. The Currency Act of 1751 prohibited bills of credit from being legal tender for the purposes of payment in any private obligations, prohibited any extension of the redemption period for outstanding bills, and required immediate dismissal of any governor who violated the Act. ${ }^{324} \mathrm{~A}$ principal justification stated in the Act of 1751 was that, by making the depreciating paper money legal tender, "all debts of late years have been paid and satisfied with a much less value than was contracted for, which

318. Id. at 336-37.

319. BROCK, supra note 14 , at 218 \& $n .92$.

320. The transformation to a hard money system nevertheless led to further periods of currency scarcity and economic hardship. In 1748, Thomas Hancock wrote in his letter books that "Peace hath put a stop to all our trade" and that money had become "monstrously scarce." BAXTER, supra note 69, at 111-12 (quoting the papers of Thomas Hancock). Referring to the return to a hard money system, Hancock wrote in 1750 that "This $\mathrm{d}$ - $\mathrm{d}$ Act ... has turn'd all Trade out of doors and it's Impossible to get debts in, either in Dollars or Province Bills." Id. Moreover, Hancock complained that the move to hard money made Massachusetts's creditors lose in relations with other colonies. According to Hancock, merchants were

greatly perplex'd in Trade, or rather none at all, \& the people for debts largely to us at Connect $\mathbf{R}^{\mathrm{d}}$ Island \& $\mathbf{N}$. Hampshire, tell us we must come there \& take our pay in their money, which is no better to us than oak leaves, Distress and Ruin attend this Province if no Act to settle the others on the footing we are on, \& you'l find worse Remittances than ever you had from this country.

Id. at 112 .

321. An Act for Drawing Bills of Credit (1749), reprinted in 3 ACTS AND RESOLVES PUBLIC AND PRIVATE OF THE PROVINCE OF MASSACHUSETTS BAY, supra note 164, at 430-441.

322. Id. at 434 .

323. The fear that only the wealthy would have access to hard money after the monetary transformation proved unfounded. Although Hutchinson may be slightly biased on this point, he argued:

[I]t was as easy for a frugal industrious person to obtain silver, as it had been to obtain paper....

... From an aversion to a silver currency, the body of the people changed in a few months, and took an aversion to paper, though it had silver as a fund to secure the value of it.

3 HUTCHINSON, supra note 154 , at 6-7.

324. BROCK, supra note 14, at 237-39. Sometime later, the Massachusetts government issued treasury notes, redeemable at a specified time in silver with interest, that represented the continuation of the currency finance system. These notes, however, did not circulate as a medium of exchange (they were an investment security), and the government meticulously enforced their provisions. E. JAMES FERguson, THE POWER OF THE PURSE: A HISTORY OF AMERICAN PUBLIC FINANCE, 1776-1790, at 7, $10(1961)$. 
hath been a great discouragement and prejudice to...trade and commerce." 325

New England's experience with currency policies in the first half of the eighteenth century led to a qualified receptiveness to these restrictions. Soon after the adoption of the Act of 1751, however, merchants in England began promoting the extension of the restrictions-in particular, the prohibition on making bills of credit a legal tender-to the middle atlantic and southern colonies. They ultimately succeeded with the enactment of the Currency Act of $1764 .{ }^{326}$ The Currency Act of 1764 was received with great protest, particularly by the merchants of New York City and Philadelphia. ${ }^{327}$ The Act was ultimately repealed in 1774 , but by that time, as the monetary historian Leslie Brock describes, "the resentment aroused by the restraints of the Currency Act of 1764 had already added itself to the forces operating to widen the breach between mother country and colonies." ${ }^{328}$

\section{A CURRENCY POLICY EXPLANATION OF TRENDS IN DEBT LITIGATION}

Current legal historical scholarship advances the position that a steadily increasing volume of debt litigation signals steady economic expansion and commercialization in the first half of the eighteenth century. In the modernization account, the volume of civil litigation serves as a proxy for the outstanding number of contracts: Thus, economic development during the first half of the eighteenth century led to an increase in the total number of contracts, which resulted in a corresponding increase in the number of lawsuits based on claims related to those contracts. ${ }^{329}$ As has been shown, however, both economic studies and contemporary accounts suggest that there was little economic growth during the period; and surely not steady economic growth. This Part shows how analysis of the complex and volatile transition to a paper money economy can largely explain colonial litigation trends and legal developments.

\section{A. The Modernization Analysis of Debt Litigation Data}

Figure 3 presents Bruce Mann's and Cornelia Dayton's empirical findings. Cornelia Dayton measured debt litigation volume in decade-long intervals in the New Haven, Connecticut, County Court and found an

325. An Act To Regulate and Restrain Paper Bills of Credit in His Majesty's Colonies (1751), 24 Geo. 2 , c. 53 (Eng.).

326. For a discussion of the tensions leading to the Currency Act of 1764, see BROCK, supra note 14, at 465-527; and ERNST, supra note 45, at 43-88.

327. BROCK, supra note 14, at 524-25.

328. Id. at 527.

329. See supra note 11 and accompanying text. 
exponential increase in litigation volume over the period from 1670 to $1750 .{ }^{330}$ More particularly, she found that the debt caseload increased each decade between 1710 and 1750 at rates ranging from $80 \%$ to $120 \%$, which far exceed population growth. ${ }^{331}$ To Dayton, these findings reveal a link between increases in litigation volume and the presumably greater economic prosperity during this period. ${ }^{332}$

FIGURE 3. CORNELIA DAYTON'S AND BRUCE MANN's DATA:

DEBT CASES, NEW HaVEN AND HaRTFORd COUNTIES

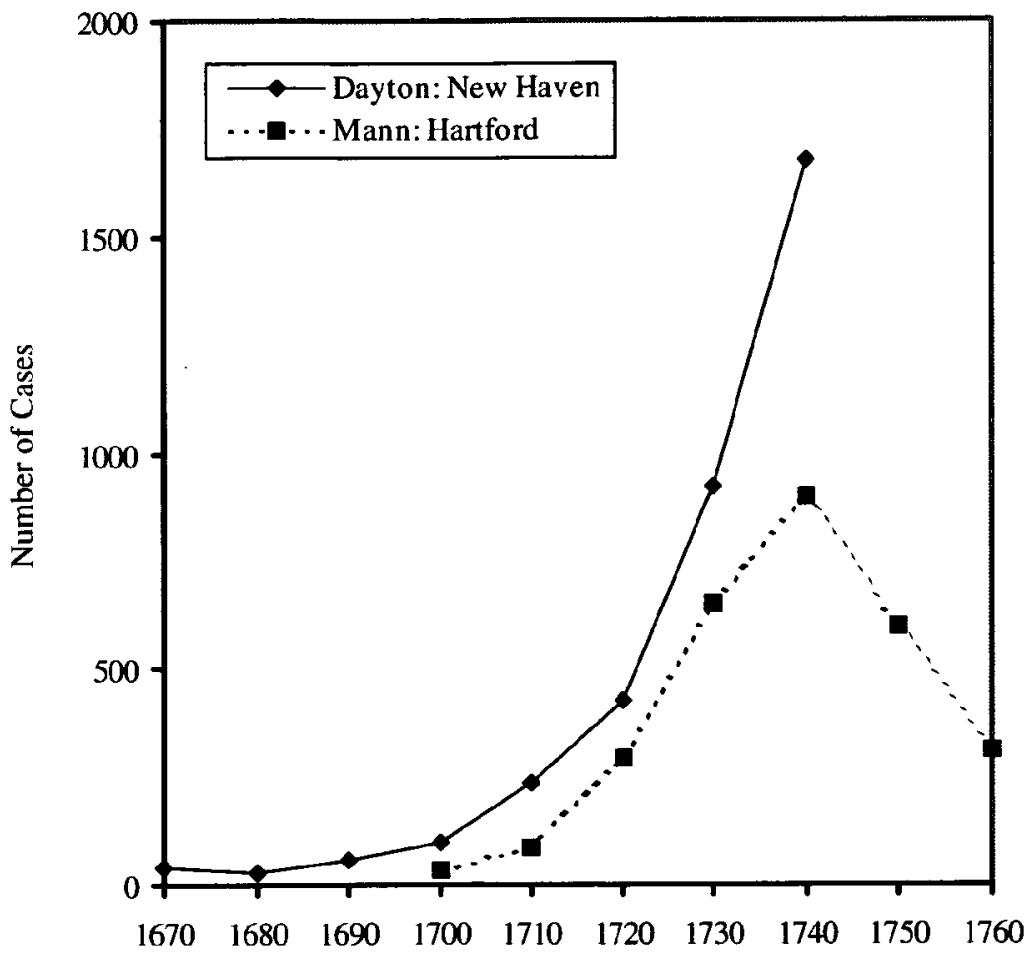

Sources: CoRnelia Hughes Dayton, WOMEn Before the BaR: Gender, LAW \& Society IN CONNECTICUT, 1639-1789, at 85 tbl.2 (1995); BRUCE H. MANN, NEIGHBORS AND STRANGERS: LAW AND COMMUNITY IN EARLY CONNECTICUT app. tbl.1 (1987).

Mann's data from the Hartford County Court show a similar general exponential increase in litigation exceeding population growth from 1700 to

330. DAYTON, WOMEN BEFORE THE BAR, supra note 7 , at 85 tbl.2.

331. See id. at $90-91 \&$ n.38.

332. See id. at $90,94-95$. 
$1740{ }^{333}$ Mann used a methodology that differed slightly from Dayton's: He calculated the number of debt cases in the first and fifth years of each decade (the number for 1700 , for example, includes the total of cases in 1700 and 1705). ${ }^{334} \mathrm{He}$ found that, over this period, the number of debt cases increased fifteenfold, which, like Dayton, he attributes to modernization. In contrast to Dayton's findings, however, Mann's data show a notable decline in litigation after $1740 . .^{335}$ As mentioned above, Mann attributes the particularly high litigation volume in 1740 to an unanticipated decline in farm prices and a resulting high rate of loan default. ${ }^{336}$ Mann does not, however, explain his statistical finding of a subsequent decline in debt litigation volume after 1740 . The decline in litigation volume would be consistent with Mann's theory only if the New England economy declined dramatically after $1740 .{ }^{337}$

\section{B. Currency Crises and Debt Litigation Volume}

As has been described in previous Parts of the Article, close examination of the economic implications of currency policies suggests the possibility of a direct correlation between currency crises and trends in the volume of debt litigation. This correlation is supported by contemporary accounts, which reveal a widespread concern about the substantial increases in litigation volume coinciding with times of fluctuating currency values. Contemporaries viewed currency policies as affecting litigation in two ways. First, depreciating currency (see Figure 2), in combination with legal tender rules permitting payment of the nominal sums of contract debts, provided an incentive for debtors to default on payment agreements. By postponing the judgment, debtors were able to benefit from the decrease in value of the monetary amount to be repaid. In a 1743 pamphlet, one writer claimed:

This [legal tender] Law ... habituat[ed] Debtors to suffer themselves to be sued for indisputable Debts, and to appeal from Judgments obtain'd against 'em upon their own Defaults to the Superior Court merely for Delay; and as the Fees of the Courts of Judicature were further lessen'd (during the Continuance of this Law) by the depreciating of the Bills, so this Sort of Actions

333. MANN, supra note 7 , at 33 n.48, 171 tbl.I.

334. Id. at 171 tbl.I.

335. Id.

336. See supra note 11.

337. Quite similarly, Rosen discovered that, in the Mayor's Court in New York in the late $1690 \mathrm{~s}$, there were 9.1 cases initiated for every thousand city residents, and in the mid-1750s, there were 15.9 cases per thousand people. Rosen, Courts and Commerce, supra note 7, at 147. Here, too, this increase in litigation is attributable to modernization. 
multiply'd in Proportion, to the great Hurt and Scandal of the Country; insomuch that the Number of such Suits within the Province was increas'd during this Administration, viz. between the Years 1730 and 1742 , to near double what it was before. ${ }^{338}$

Second, in times of currency scarcity, more debt contracts ended in litigation because debtors became unable to raise funds to pay their debts. A commentator in 1736, for example, claimed that if more bills of credit were circulating, "that would prevent hundreds of Law-suits which are brought into the Courts only through the scarcity of Money." 339

In order to test the hypothesis that litigation rates were affected by currency policies, I calculated the annual number of cases brought for repayment of goods and services in the Plymouth Inferior Court of Common Pleas over the period from 1718 to $1751 .^{340}$ Plymouth County, south of Boston, had a population of approximately 25,000 during the period examined. ${ }^{341}$ The county represented a mix of rural areas and towns with strong commercial ties to Boston. As indicated, paper money passed at par throughout the New England colonies, so currency crises were likely to affect neighboring counties and colonies similarly, although perhaps not simultaneously.

Figure 4 shows the total number of cases brought before the Plymouth Court of Common Pleas to reclaim either money or durable goods. This total includes suits based on credit instruments, such as notes, bonds, bills, and book accounts; suits for money or goods based on no instrument; cases for nondelivery of goods; and cases to collect wages. The total does not include cases regarding land (cases for past due rent or trespass and ejectment actions); cases for money owed by apprentices to their guardians; and cases based upon torts such as slander and intentional harms. ${ }^{342}$

The changes in the volume of debt cases illustrated in Figure 4 appear substantially inconsistent with the hypothesis that economic expansion and

338. ENQUIRY, supra note 190 , reprinted in 4 COLONIAL CURRENCY REPRINTS, supra note 20, at 162-63 (internal citation omitted). For a discussion of the impact of court fees on litigation timing during this period, see Priest, supra note 24, at 2424-39.

339. THE MELANCHOLY STATE, supra note 251 , reprinted in 3 COLONIAL CURRENCY REPRINTS, supra note 20 , at 144.

340. The jurisdiction of the Court is described supra note 77 . For a discussion of the publication of the court records and the representativeness of Plymouth County within New England, see William E. Nelson, Introduction to 1 PLYMOUTH COURT RECORDS, supra note 77, at 1 , passim. Nelson, for example, states that "throughout the period [1686 to 1859] the county had a pattern of economic growth and change that mirrored that of Massachusetts as a whole." Id. at 3.

341. See id. at 5.

342. My intention was to count the cases related to commercial debts of many kinds that would have been affected by economic conditions. Some of the cases excluded may have fallen into that category: Cases for past-due rent, for example, would be likely to increase in a time of economic depression and currency scarcity. I decided, however, to establish clear guidelines for inclusions and exclusions to obtain consistent, if not all-inclusive, results. 
legal formalization are highly correlated with an increasing litigation volume. Dayton's New Haven County data in Figure 3 show exponentially increasing debt litigation throughout the period from 1680 to 1750 . Mann's Hartford County data show a steady increase in litigation volume in the period from 1700 to $1740,{ }^{343}$ and then a steady decline, with litigation volumes in 1750 and 1760 lower than the volume in 1730. Mann and Dayton allude to a decline in agricultural prices in 1740 that may account for the substantial increase in debt cases in that year. ${ }^{344}$ Their arguments suggest, however, that these changes reflect only a single variation from the trend of increasing litigation volume paralleling economic expansion.

FiguRe 4. Debt Cases: Plymouth, 1718-1751

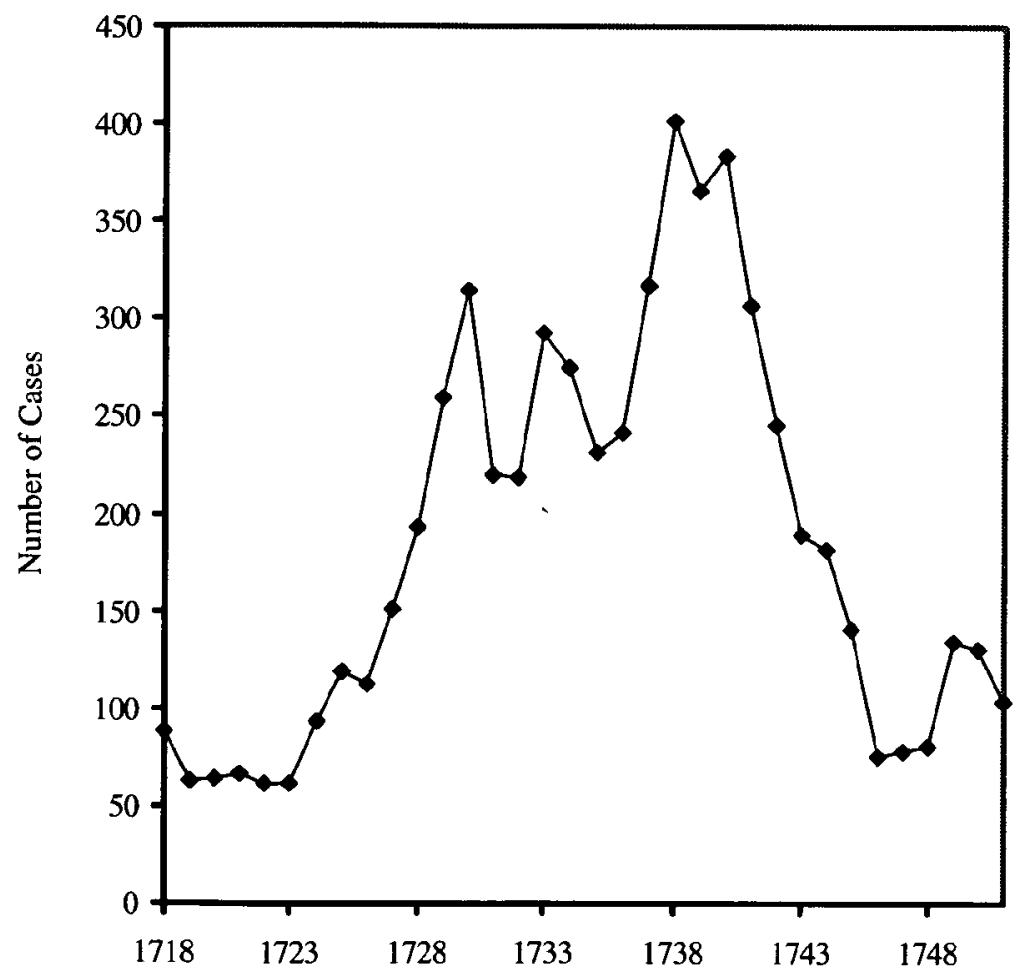

Source: 5-7 Plymouth COURT RECORDS, 1686-1859 (David Thomas Konig ed., 1978).

343. Indeed, according to Mann, greater commercialization led book account cases to increase by $600 \%$ during this period, despite the reduction in percentage in relation to cases on bonds and promissory notes. MANN, supra note 7, at 28.

344. See supra notes 11,336 and accompanying text. 
Figure 4 shows first that, while there is surely a rise in the volume of debt litigation after 1723, the growth does not demonstrate the steadiness predicted by the modernization hypothesis. Although the decade-end numbers of Figure 4 show, as Mann suggests, a "steady" increase to 1740 and decline thereafter, it seems evident that the "steady" growth in litigation found by Mann and Dayton is the result of counting cases in fiveyear and ten-year intervals, rather than annually. Mann's data and Dayton's data conceal substantial annual variation.

Second, Figure 4 confirms Mann's finding for Hartford of a sharp drop in debt litigation after 1740. Mann explains that after the recession of the 1740 s, "prosperity returned to farmers in Connecticut." ${ }^{345}$ A reduction in litigation during a time of economic prosperity, however, is inconsistent with the modernization interpretation. Figure 4 shows that litigation volume from 1746 through 1749 was roughly equivalent to the litigation from 1718 through 1724. The modernization theory cannot explain these relationships.

In contrast, Figure 4 shows a close relation between debt litigation and currency events. As explained in Part III, contemporary accounts suggest that scarcity of currency compelled the resort to barter at various points in the first half of the eighteenth century- 1720 to 1721,1733 to 1734 , and 1738 to 1741 . Figure 4 shows a low litigation volume through 1723. After 1723, the litigation volume began to increase sharply, with a peak in 1730 . In 1731 and 1732, the volume of litigation declined by approximately onethird, then increased and peaked again in 1733 and 1734. The final peak, more extreme than those preceding it, occurred in the period from 1738 to 1740. After 1740 , litigation volume declined steadily-still remaining at high levels until 1744, but falling to early 1720 s levels in 1746 .

As Figure 4 shows, the currency crisis of the period 1720 to 1721 had no visible impact on litigation. Prior to 1721, however, Massachusetts's bills of credit had been retired on schedule, with perhaps some minor exceptions, and had not yet substantially depreciated. ${ }^{346}$ Because the residents of Massachusetts had never experienced prolonged depreciation of the bills of credit, they might have had no expectation that the bills would decline in value in the future. ${ }^{347}$ Moreover, because there had been little currency depreciation, court fees were still high in real terms during this period. Debtors therefore had less incentive than in later years to use legal process to delay payment of their debts. This explanation is speculative. There may be other reasons that litigation volume did not increase; for example, the litigation data might more accurately reflect economic conditions, and the contemporary accounts exaggerate the crisis.

345. MANN, supra note 7, at 64.

346. See supra text accompanying note 212; Figure 2.

347. Ronald Michener suggested to me that in 1720 , creditors may have anticipated a deflation that would restore former price levels. 
With respect to each of the other periods of extreme barter and currency crisis, however, Figure 4 shows sharp increases in litigation consistent with depreciating currency and a widespread inability to pay creditors. Again, these litigation data are deeply inconsistent with modernization: Debt litigation increased when economic conditions were the most primitive and citizens were forced, because of the absence of a stable currency, to engage in barter. More precisely, the currency events of the period from 1726 to 1741 occurred in distinct stages. The first stage, in the period from 1726 to 1727, consisted, it may be recalled, of (1) a credit crisis in England that increased demand for specie among New England merchants, and (2) the impending retirement of a large number of bills loaned out by the Massachusetts government. The government responded to the resulting currency shortage by suspending the scheduled bill retirement, and by issuing a large volume of new bills. The currency began to depreciate steadily for the first time during this period.

In 1730, Belcher was appointed Governor and was presented with the Instructions to increase taxes in order to retire all outstanding bills of credit beyond $£ 30,000$. There was initially an expectation that the Instructions would be followed. Political tensions led to the closing of the treasury in 1731 and 1732, and Massachusetts experienced a severe currency shortage. Massachusetts's currency problems were exacerbated over the succeeding years because of (1) the government's failure to retire the bills of credit according to schedule; (2) the flooding of the Rhode Island bills of credit throughout New England; (3) the hoarding of the Merchant's Notes; and (4) the issuance of three years of public funds at one time. The government's position changed more dramatically in 1738 , when it began to redeem all outstanding bills of credit and to impose substantial general taxes on the population to accumulate the necessary redemption funds. The period from 1738 to 1741 was a time of extreme currency scarcity and economic stagnation.

As can be seen in Figure 4, the volume of debt litigation began increasing sharply in 1726, when the currency first began to depreciate steadily. The volume of debt cases reached an initial peak in 1730, the year the Instructions were announced. Litigation volume may have dropped in 1731 and 1732 because the Instructions were likely to have created the expectation that currency values would be restored: Debtors who anticipated a deflation would have wanted to avoid the delays and fees associated with litigation. In a deflation, delay will increase the cost in real terms of an outstanding debt. The number of cases rose sharply in 1733 and 1734. 1733 and 1734 were years of tremendous currency uncertainty: As mentioned, Rhode Island notes were flooding into the colony; the government routinely failed to retire its bills on schedule; the Merchant's 
notes were issued and then hoarded; and the government issued three years' worth of new bills of credit at one time. Moreover, the steady depreciation of this period would have lowered the cost of court fees in real terms. Litigation volume reached its highest level in 1738, when the government began to retire bills of credit through taxation in compliance with the Instructions. The volume of litigation remained high throughout the currency crisis of 1739 to 1740 , then dropped off dramatically after 1740 .

Governor Shirley's policies of 1742-requiring judgments to be adjusted to reflect currency values and increasing court fees-surely contributed to the drop in litigation. To the extent it was effective, the indexing statute prevented debtors from benefiting from depreciation by using legal process to delay payment of their debts. Increasing court fees also likely lowered the litigation volume. Court fees had declined in value in real terms with the depreciation of the currency. Increasing the fees increased the cost to debtors of allowing themselves to be sued and therefore reduced the incentive to litigate. The participation of Massachusetts residents in battles against France from 1744 to 1748 was likely to have further reduced the litigation volume. In 1750 , the colony returned to a hard-money system; gold and silver became the exclusive legal tender in Massachusetts. The return to an exclusively hard-money system led to a reduction in the litigation volume to that of 1720 . This is not to say that the New England economy was the same in 1750 as in 1720 , as the modernization hypothesis implies: Rather, only that levels of currency stability were similar.

Figures 5 and 6 extend the analysis. They break down the more general statistics in Figure 4 to show the volume of cases according to specific credit instruments-bonds, book accounts, and promissory notes. Figure 5 shows the volume of cases brought on bonds and book accounts. Again, one might expect from the modernization theory that litigation based on primitive book-account transaction methods would steadily decline over time. As is evident, however, the litigation trends here offer a sharper depiction of the general litigation trends shown in Figure 4: The volume of litigation relating to bonds and book accounts peaked in 1730, 1734, and 1738. In addition, as before, the volume of litigation dropped significantly after 1740 . Again, quite contrary to the predictions of the modernization hypothesis, the volume of this commercial litigation after 1744 was roughly equal to the volume from 1718 through 1724 .

Figure 6 illustrates the number of cases brought on promissory notes. This graph shows a steady increase in note litigation throughout the period. Figure 6 appears to provide the greatest support for the modernization hypothesis, at least in its simple form: The figure shows a relatively steady increase in litigation involving notes from a low in 1718 to a peak in 1740 . 
FIgure 5. BOND AND BOOK ACCOUNT CASES: PlyMOUTH, 1718-1751

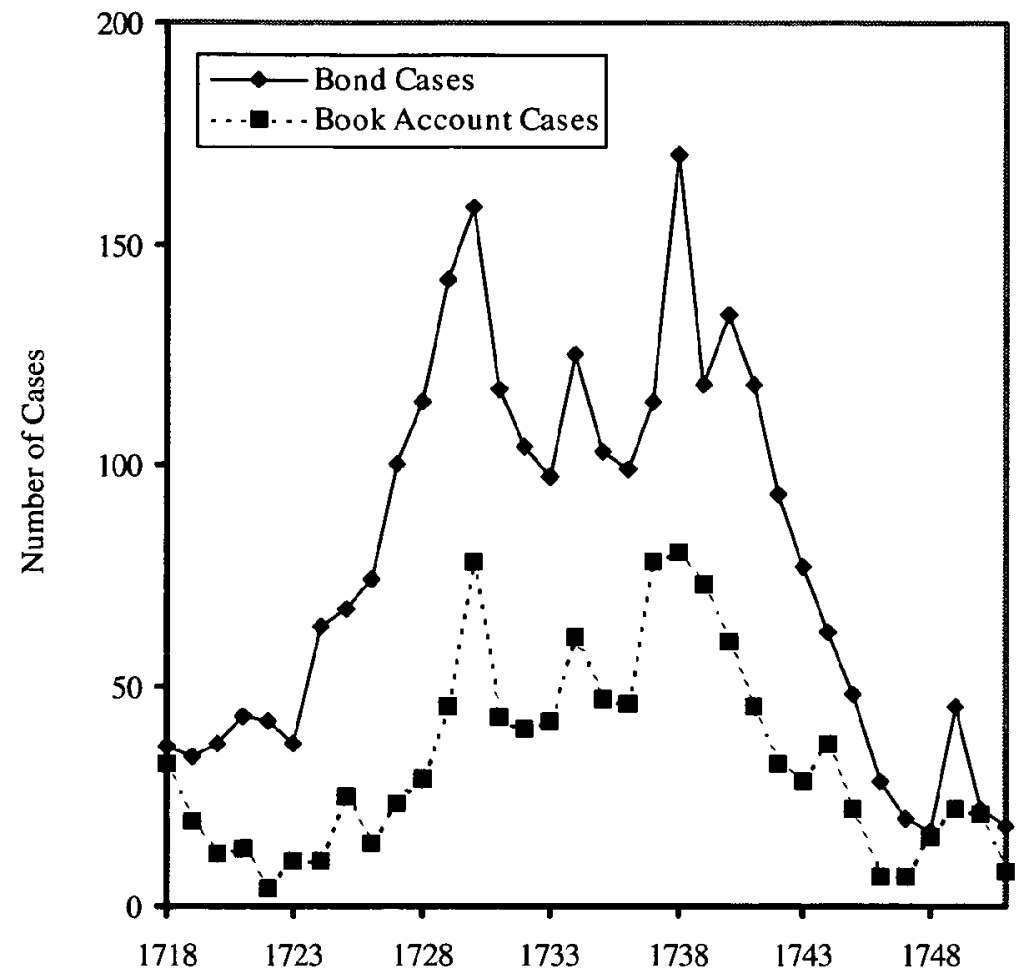

Source: 5-7 Plymouth Court ReCORdS, 1686-1859 (David Thomas Konig ed., 1978).

Figure 6, however, shows a sharp decline in litigation involving notes after 1740, a finding once again inconsistent with the modernization explanation, but consistent with the effects of currency stability.

The relatively steady growth in note litigation in the period preceding 1740 does not contradict the currency explanation. Promissory notes were short-term debts to be repaid in money. As described, they were assignable, and thus functioned as a medium of exchange in contexts in which the ability of the issuer to repay the debt could be monitored. ${ }^{348}$ Thus, their use increased during times of currency shortage when there was demand for short-term debt. Litigation on notes was generated when the holder of the note became uncertain about the ability of the issuer to uphold his or her promise. This was likely to be the case during the economic and litigation

348. See Neal, supra note 89 , at 162-63. 
FIGURE 6. NOTE CASES: Plymouth, 1718-1751

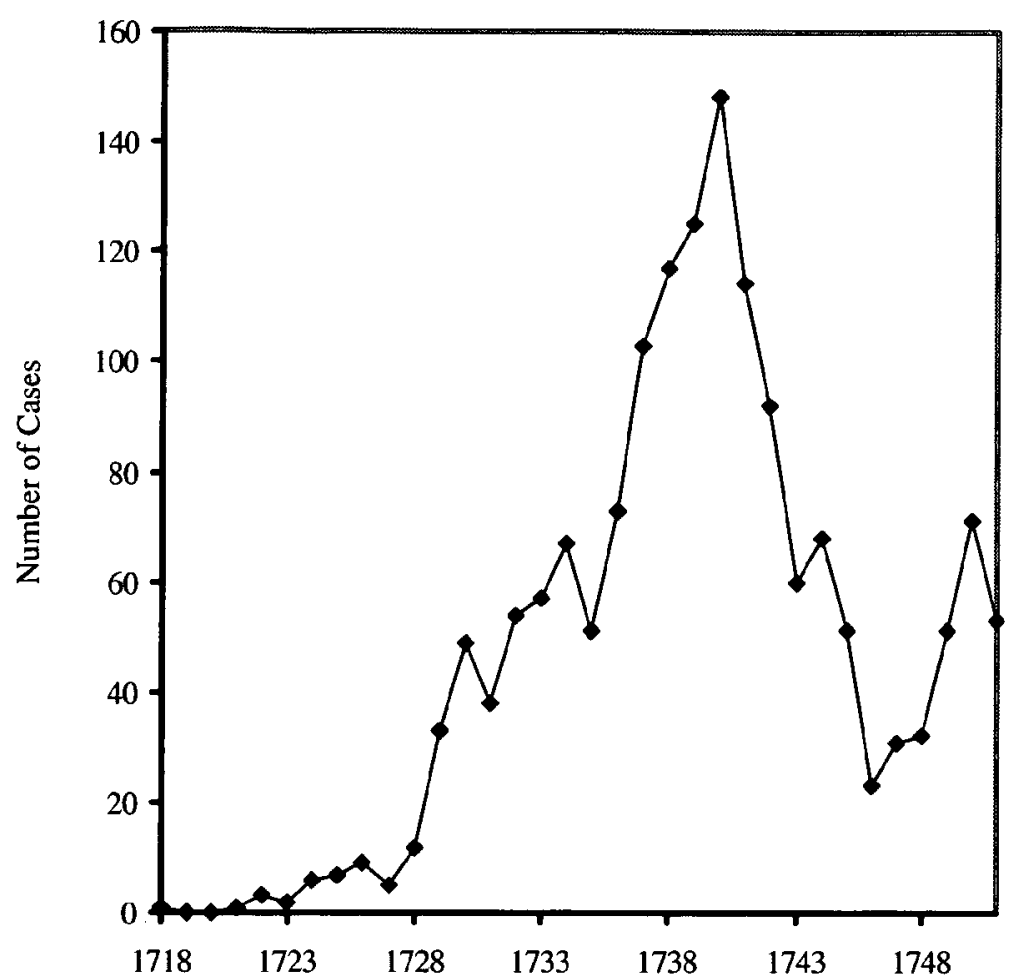

Source: 5-7 Plymouth Court ReCORdS, 1686-1859 (David Thomas Konig ed., 1978).

crises of 1726 to 1730,1733 to 1734 , and 1738 to 1741 , as debtors increasingly became unable to repay their debts. The principal difference between the trend in note litigation, shown in Figure 6, and the changes in bond and book account litigation, shown in Figure 5, is the absence of an increase in note litigation during the crisis of 1726 to 1730 . The peaks in 1734 and 1740 and the decline thereafter are otherwise quite similar.

Finally, Figure 7 shows the volume of litigation involving suits demanding repayment in goods rather than money, such as cases based on bonds or notes that promised payment in specific goods. The modernization historians have not specifically addressed suits of this nature. It is not obvious, however, why suits for repayment in goods would increase progressively with economic growth. Indeed, it is more plausible that economic growth would lead to a decline in such suits, as the colony became more generally commercialized. 
FIGURE 7. SUITS FOR GOODS: PLYMOUTH, 1718-1751

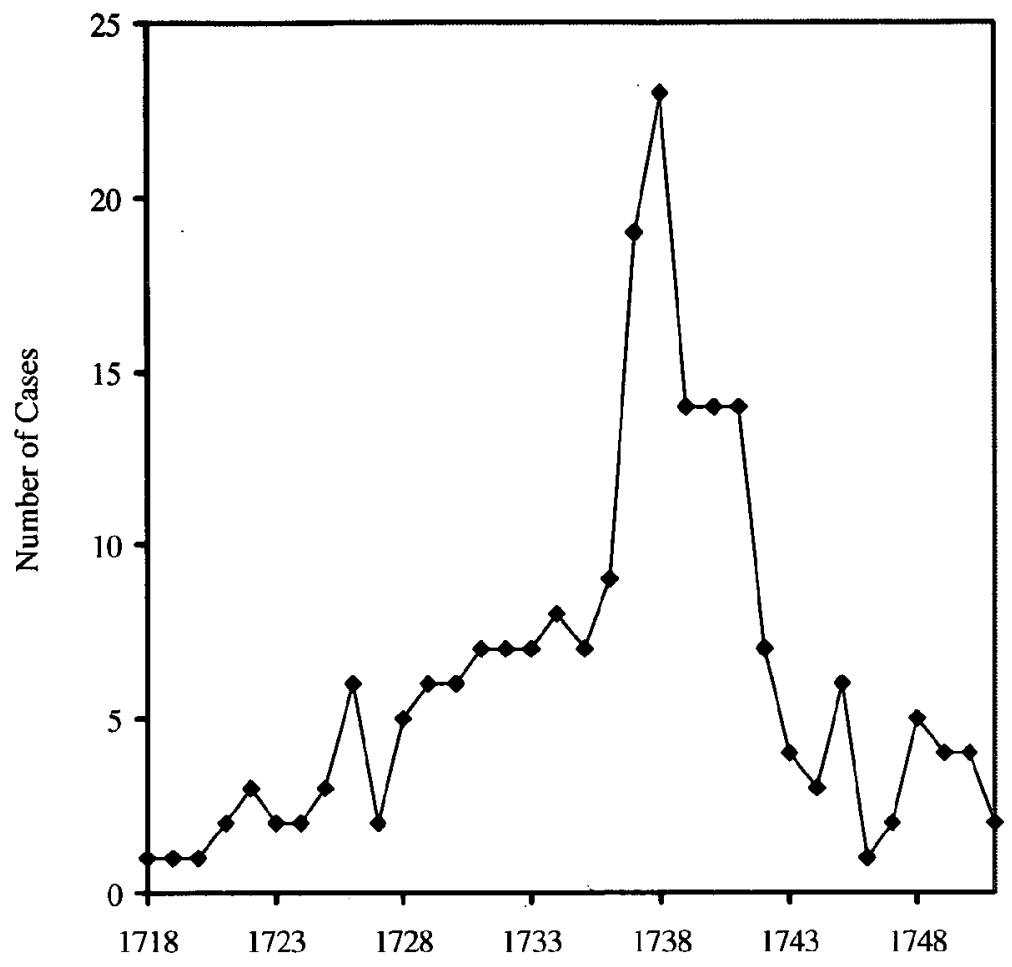

Source: 5-7 Plymouth Court ReCORDS, 1686-1859 (David Thomas Konig ed., 1978).

The volume of litigation regarding payment in goods as shown in Figure 7 tracks generally the trends observed in the more commercial litigation of the preceding Figures. Repayment in goods is more likely to be sought in times of currency scarcity, especially if the absence of currency makes a money judgment uncollectible. Here, litigation volume peaked in 1740. Again, consistent with the currency crisis explanation, litigation volume declined dramatically thereafter, remaining at very low levels after $1742 .^{349}$

These graphs suggest that the modernization argument that litigation rates reflected "economic expansion" or can be attributed to "growing commercialization" is inadequate. The fact that litigation rates increased

349. The small sample size of cases demanding repayment in goods makes the interpretation somewhat vulnerable. Contemporary accounts of the general reversion to barter during this period, however, suggest that a similar study with broader scope-one that included, for example, the Suffolk County Courts (Boston)-might reveal a result consistent with that presented here: fewer monetary damage awards during currency crises. 
exponentially during times of problems with Massachusetts currency, and then declined to very low levels following the adoption of indexing statutes and a hard money system, indicates that the volume of litigation was determined principally by the economic effects of uncertain currency policies, and not by (questionably) growing prosperity.

New England's litigation crises of the first half of the eighteenth century, thus, directly resulted from a combination of extreme depreciation of the currency; currency scarcity; legal tender laws permitting repayment in colonial bills of credit without regard for depreciation; and, particularly during the period between 1738 and 1741 , recession. When currency is scarce and there is reversion to barter, demand for consumer goods drops, interest rates rise, and prices decline, as those who need money are willing to sell their assets at lower prices. ${ }^{350}$ During such periods, more business deals fail to go forward and many lose money. In the recessions of the 1730 s and 1740 s, as currency policies led to an environment with an inadequate medium of exchange (either scarce or depreciating), creditors called in their existing debts to gain money to engage in trade. Because of the lack of money in circulation, however, their debtors were unable to pay, and were themselves required to call in their outstanding debts to avoid foreclosure on their property. Litigation volume increased as each sued down the "chain of debt" to get money to pay off his or her creditors. ${ }^{351}$

The correlation between currency events and litigation volume undermines the assertion of the modernization hypothesis that increases in the volume of litigation were principally caused by commercial expansion. The correlation does not, however, preclude the possibility that commercialization contributed to an increase in the volume of litigation during the currency crises. Indeed, it is highly likely that the initial issuance and circulation of currency increased the total number of outstanding contracts, because currency reduced the problems of a barter economy that had previously limited exchange and reduced profit-making opportunities. Thus, the litigation explosion attending each currency crisis was more dramatic than it would have been without paper money's positive impact on commercialization and market development.

The inadequacy of the modernization theory derives from its assumption of a-stable currency. If currency were entirely stable and circulated in an optimum quantity, and if no other legal rules distorted colonists' propensity to file lawsuits, one might expect litigation volume to

350. The author of $A$ Word of Comfort, for example, complained that when currency is scarce, "Moneyed Men higgle down every thing; and use many unfair Artifices to sink and lower the Price of what comes to the Market." A WORD OF COMFORT, supra note 214, reprinted in 1 COLONIAL CURRENCY REPRINTS, supra note 20, at 185.

351. See Chu, supra note 194, at 92 (describing creditor anxiety in the 1785 Massachusetts recession). 
rise proportionately with economic expansion: An increase in the absolute number of cases brought to trial might approximate the increase in number of contracts formed in response to economic and population growth (or decline). ${ }^{352}$ The chaotic state of New England's public currency during the first half of the eighteenth century, however, suggests that currency crisis is the more likely explanation of exponential increases in litigation volume during these periods. ${ }^{353}$

\section{COLONIAL LAW AND THE ECONOMY: A REINTERPRETATION}

The close correlation between currency crises and periods of exponentially increasing litigation volume reveals the need for a new

352. The modernization theorists, however, also claim that the law was becoming more predictable, a claim inconsistent with increased litigation rates. Litigation volume will rise with economic expansion only when the rate of economic expansion is greater than any diminution in the level of legal uncertainty. See supra text accompanying note 12 .

353. Legal scholars discovered various other changes in eighteenth-century civil litigation that they interpreted as deriving from modernization: During the period from 1710 to 1720 , formal credit instruments replaced book accounts as the form of debt agreement most commonly found in litigation, and pleadings became more technical and legal. During the 1730s and 1740s, defendants increasingly failed to contest debt cases or to avail themselves of jury trials. Mann argues that these changes, in combination, created a more rationalized legal system that promoted certainty and predictability over responsiveness to community norms. To Mann, each change represents a response to the new demands of an expanding economy. But given that the economy was not expanding, how can these changes be explained?

The timing of the transformation is revealing: As described by Mann, book account cases declined most dramatically between 1700 and 1720-the same period in which Mann found a radical decline in jury trials and pleadings on the merits, and a corresponding increase in the percentage of uncontested debt cases. See MANN, supra note 7, at 183 \& tbl.13 (jury trials); id. at $185 \&$ tbl. 15 (pleadings); id. at $172 \&$ tbl.2 (contestation levels). The fact that this legal transformation occurred between 1710 and 1720 strongly suggests that the widespread circulation of government paper money largely explains these changes. Paper money replaced coins as the principal medium of exchange in New England during the period from 1710 to 1715, supra text accompanying notes 169-172, the exact period when book accounts declined as a percentage of all cases. Thus, rather than resulting from legal modernization propelled by an expanding economy, the transformation to greater use of formal credit instruments is most plausibly a direct result of the widespread circulation of paper money: The availability of paper money allowed greater use of cash in exchanges and reduced the need for debt agreements, such as book accounts, to serve as "currency." Thus one can see an increase in the percentage of formal credit instruments, with all of the attendant changes-fewer jury trials, fewer pleas of the "general issue" and more default judgments-as deriving from the transition from an economy plagued by currency scarcity to a cash economy.

Mann explains some of the changes as resulting from an increase in cases represented by lawyers, see MANN, supra note 7, at 93-100, which, it may be argued, cannot possibly be related to currency circulation. There is currently substantial debate among legal historians concerning the extent to which lawyers influenced legal change during the first half of the eighteenth century. Gerard W. Gawalt argues that lawyers had little influence on legal change because there were, in fact, few lawyers practicing in New England during the period. GERARD W. GaWALT, THE Promise of POWER: THE EMERGENCE OF THE LEGAL PROFESSION IN MASSACHUSETTS, 17601840 , at $7-35$ (1979). He found, for example, that in 1740, Massachusetts had only fifteen practicing lawyers (one per 10,108 people). Id. at 14 tbl.1. Peter Hoffer follows Gawalt's analysis and argues that lawyers were a consequence, not a cause, of legal and economic development. Hoffer, supra note 7, at $305-06 \&$ n. 34 . 
interpretation of the relation of law to economic development in colonial New England. This Part reassesses two aspects of the relationship between law and the economy in this period. First, I propose that currency policy is central to the creation of law through decisionmaking by judges and juries. In the colonial period, currency policies were formulated within an institutional structure highly vulnerable to political tensions. ${ }^{354}$ The impact of currency policy on litigation therefore suggests a direct connection between political processes and the "law" generated within courthouses. Second, the fact that an escalation of litigation on debts occurred during times of recession and currency crises, rather than during periods of economic growth, suggests the need to reexamine the role of courts in the colonial economy. In light of the fact that an important function of the colonial court system was to manage litigation crises, how should its role in advancing economic development be reassessed? This Part analyzes the relationship between common-law litigation and a variable market economy during the first half of the eighteenth century.

\section{A. The Centrality of Currency Policy and Politics to Debt Litigation Trends}

Colonial legal historical scholarship has almost exclusively characterized the principal sources of court-made law either as judicial efforts to maintain community cohesion and consensus or as judicial responses to economic relationships emerging out of local social and market conditions. ${ }^{355}$ The importance of currency policies and macroeconomic conditions in propelling litigation during particular periods reveals that legal historians' narrow focus on highly localized sources of law has been misguided. To the extent currency policies affected litigation trends, "law" should not be characterized as created exclusively by endogenous processes. The influence of currency issuance and currency policies on civil litigation reveals that even litigation on book accountsthe most community-oriented form of economic relations-reflected colonial responses to conditions of barter generated by decisions made by Parliament and the English Board of Trade, decisions that occurred thousands of miles away. Local communities and the norms prevailing within them were irrelevant to the process of establishing and implementing currency policies. Indeed, as a source of law, currency policies were

354. As emphasized in Bray Hammond's classic work, Banks and Politics in America, supra note 48 , American banking and monetary policy was, in fact, highly susceptible to political tensions throughout the pre-Civil War period.

355. See the description of Morton Horwitz's view of colonial law, supra text accompanying notes 1-6, and the summary of Bruce Mann's and Cornelia Dayton's work, supra notes 7-11 and accompanying text. 
anything but sensitive to the moral climate of local communities. Neither were they driven by economic growth and local market conditions.

The problems generated by currency policies-including skyrocketing litigation-instead can largely be attributed to weaknesses in the institutional structure of colonial governments. The currency policies of each colony were determined by the decisions of elected assemblies, constituted by members representing the various interests of debtors, creditor groups, merchants and other sectors within the society. ${ }^{355}$ This in itself was likely to lead to greater uncertainty, for example, than the currency policies of the United States in recent years, which are determined by unelected officials, purposefully removed from the political process to the extent possible. ${ }^{357}$ Intracolony political dynamics, however, were only one aspect of the problem. As has been described, the policies were also the outcome of a struggle for authority between the English Parliament and Board of Trade on the one hand and the colonial legislatures, who resisted English authority on the currency issue long before the famous tensions of 1765 and onward, on the other. The English were principally focused on safeguarding profits for English merchants, and their goals often did not coincide with the interests of the colonies.

Each of these tensions, among the English and colonial governments and among various interests within the colonies, generated an instability that stood in the way of sound currency policy. The inability during this period of the government to develop a stable currency within the existing institutional structure was a principal reason why the Framers prohibited a government-issued medium of exchange in the U.S. Constitution. ${ }^{358}$ Private banks dominated the market for currency between the Revolution and the Civil War. Not until the widespread issuance of Greenbacks to finance the

356. For a discussion of the political tensions within the Massachusetts assembly during the currency crises of the 1730s and 1740s, see Billias, supra note 203.

357. Government paper money has a historically unprecedented stability today in the United States largely because currency policy has been removed from the realm of politics and determined within the Federal Reserve, a remarkably independent institution. The Federal Reserve has been able to generate tremendous confidence in the United States dollar in large part because it has committed itself not to use currency policy to achieve political ends. This approach is the result of lessons learned the hard way throughout the history of the country, most recently with the failings of monetary policy during the Great Depression of the 1930s.

358. It is uncontroversial that the Framers did not view the Constitution as giving Congress the power to issue paper money to be invested with the status of legal tender. Discussions of state and federal money powers at the 1787 Constitutional Convention are documented in detail in Kenneth W. Dam, The Legal Tender Cases, 1981 SUP. CT. REv. 367, 382-90. See U.S. CONST. art. I., $\S 10$, cl. 1 ("No State shall ... coin Money; emit Bills of Credit; make any Thing but gold and silver Coin a Tender in Payment of Debts; [or] pass any ... Law impairing the Obligation of Contracts ...."). Article I, Section 8 gives Congress the "Power To lay and collect Taxes, Duties, Imposts and Excises, to pay the Debts ... of the United States"; the power "To borrow Money on the credit of the United States"; and the power "To coin Money, regulate the Value thereof, and of foreign Coin, and fix the Standard of Weights and Measures." Id. art. I, \& 8. See also HAMMOND, supra note 48, at 95-103, for a discussion of the Framers' experiences with the paper money issue in the period between the end of the Revolution and the Constitutional Convention. 
Civil War and the subsequent enactment of Lincoln's National Banking Act of 1865 , which taxed private state bank notes out of existence, did the federal government assume the responsibility of managing a national paper money with legal tender status. ${ }^{359}$

In evaluating the relationship of law to economic growth and the development of markets, one might conclude that, while New England's paper money experiments represented an advance over the previous system, in which the need for a medium of exchange was never satisfied, the colonial institutional structure lacked the stability necessary for uniformly successful currency policies. Although a principal purpose of currency issuance was to promote economic growth and the development of markets, the results in New England were highly problematic. Moreover, through the policies adopted by colonial governments, this institutional structure had a profound impact on the creation of law in colonial courthouses.

\section{B. Reassessing the Role of Courts in Promoting Economic Growth}

Although this Article suggests the centrality of currency policy to trends in litigation within colonial courthouses, the question remains whether judges during the first half of the eighteenth century in New England promoted or limited the expansion of markets through their decisionmaking processes. As has been described, there were two principal reasons why exponential increases in litigation occurred during times of currency crisis. First, during times of inflation, debtors delayed payment in order to benefit from declining currency values, forcing their creditors to sue to reclaim their debts. Second, currency crises coincided with recession conditions, and there were greater rates of default by debtors who were unable to pay their debts. Recession conditions also created uncertainty about which debtors would remain solvent, giving all creditors an incentive to sue to secure a place in line to be paid in debtors' assets before they were claimed by other creditors. These two reasons for litigation are obviously quite different: The first represents a strategy on the part of debtors to benefit from declining currency values; the second is a strategy of creditors to beat other creditors to debtors' assets, as well as an expected response to recession conditions when people are unable to pay their debts on a widespread basis. Each relates to different aspects of the colonial legal system.

359. See Dam, supra note 358, passim, for a discussion of the issuance of Greenbacks and the Legal Tender Cases, which vested them (ultimately) with legal tender status. See also Veazie Bank v. Fenno, 75 U.S. (8 Wall.) 533 (1869) (upholding the constitutionality of the National Banking Act). 


\section{Nominalism}

As has been described, debtors' use of legal process to benefit from changes in currency value was a direct result of the consistent application of the nominalism doctrine throughout the currency crises of the 1730s and 1740s. Nominalism requires debtors to pay only the amount agreed upon, irrespective of changes in currency values. ${ }^{360}$ The strict nominalism applied in colonial courts was an inflexible approach to deciding cases. An alternative might have been more flexibility, such as by requiring judges to adjust the amount debtors owed based on changes in the real value of currency.

In analyzing the economic impact of nominalism, it must be recognized that contracting parties themselves were able to set the terms of the contract according to the changes in currency value they expected. If the parties predicted a future period of inflation, they were likely to increase the amount of the debt according to the expected decline in the value of currency. If they predicted a period of deflation, they would be likely to reduce the debt amount. In an environment of uncertainty about future currency values, creditors could require an increased payment to compensate for their incurred risk. During the currency crises described in this Article, however, there were clearly changes in currency policy that could not have been anticipated in advance. It can be assumed that all or most creditors were harmed by the unanticipated skyrocketing inflation depicted in Figure 2. It does not necessarily follow, however, that a default rule for contract interpretation other than nominalism would have led to a more equitable result for creditors and debtors.

The merits of the doctrine of nominalism might be analyzed according to the central question within contract law scholarship of asking how judges should design default rules to address the problem of unforeseen circumstances. If one assumes that a particular currency policy could not have been anticipated, one can view the contract as having a "gap" with respect to that policy. The parties neglected to incorporate the likelihood of that policy within the terms of their contract. The question, then, is what is the optimal policy response for the court system to take with respect to contract gaps of this nature. Should it have adopted a policy that adjusts contracts on an individual basis, to ensure an equitable result in all cases? Or, should it penalize one of the parties for not anticipating the occurrence and incorporating the likelihood of that occurrence within the contract? Ian Ayres and Robert Gertner have analyzed this question in detail ${ }^{361}$ and have

360. Supra text accompanying notes 187-190.

361. See Ian Ayres \& Robert Gertner, Filling the Gaps in Incomplete Contracts: An Economic Theory of Default Rules, 99 YALE L.J. 87 (1989). 
suggested that courts adopt "penalty" default rules_rules that penalize one or both parties for not incorporating an unforeseen condition within the contract terms-when it is efficient, that is, "when it is cheaper for the parties to negotiate a term ex ante than for the courts to estimate ex post what the parties would have wanted." 362

Here the cost to courts of adjusting debts according to an inflation schedule would not be high (since exchange rates with pounds Sterling, which were relatively stable, were well known). The problem with a purely individualized system, however, is that judges would have to determine whether the contracting parties had in fact already incorporated the expectation of inflation within the terms of the contract. When parties did incorporate expectations about inflation or deflation within the terms of the contract, ex post adjustment by judges would be unfair. The greatest cost to the court system of a flexible, individualized approach would be in determining which contracting parties anticipated which events. Nominalism places the burden on all contracting parties to incorporate changes in currency value within the terms of their contracts.

An additional problem, however, is that a simple application of Ayres and Gertner's analysis fails to account for the way legal process can impact debt amounts. The most common complaint among creditors, it may be recalled, was that debtors used the delay inherent to litigation to benefit at the expense of creditors. Debtors declined to pay their debts, requiring creditors to sue them. At trial, debtors defaulted (often even failing to appear in court). Then debtors appealed the decision, usually obtaining an affirmance of the original judgment against themselves. In a climate of constant depreciation, creditors' greatest losses were caused by the passage of time. It may be that some creditors protected themselves against losses within the terms of their contracts, but it is hard to imagine that creditors could fully protect themselves against the costs of both inflation and procedural delay during the unprecedented depreciation of the 1730s.

Contemporaries were largely against nominalism. As has been described, one of Governor William Shirley's first acts in office was to overturn the nominalism doctrine by statute in 1742, requiring all judges to adjust litigated debts based on changes in currency value. ${ }^{363}$ While, in theory, nominalism appears to be a classic example of an efficient use of penalty default rules, it is not clear that nominalism was the optimal approach in this particular case. Massachusetts during the period from 1710 to 1742 suffered extreme changes in currency value. Contracting parties were often not likely to have been able to anticipate these changes. Moreover, the changes may have affected all contracts litigated in the

362. Id. at 93 .

363. See supra notes 306-309 and accompanying text. 
courts differently. In sum, it cannot be concluded that nominalism worsened economic conditions, but the strict application of nominalism is also not an example of a judicial measure leading to positive economic growth.

\section{The Colonial Court System and Economic Recession}

Recession conditions led to a second category of litigation that contributed to exponential increases in litigation volume during the $1730 \mathrm{~s}$ and early 1740 s. During recessions, more debtors were simply unable to pay their debts. As debtors defaulted on their debts, their creditors were likely to have trouble paying their own debts, leading the creditors to liquidate their assets by instituting lawsuits to reclaim any money which was owed to them.

Debt litigation is likely to increase during times of recession during any time period, even today. There are, however, two principal reasons why litigation volume was likely to be more sensitive to economic conditions during the colonial period than during the nineteenth and twentieth centuries. First, banking institutions were prohibited by the English throughout the colonial period, and stock markets were highly undeveloped. In the absence of banks in which to place deposits and stock markets in which to invest money, many investments were negotiated by means of debt contracts. People with assets invested their money by lending it directly to borrowers. Banks today serve the function of "delegated monitor": They serve as an intermediary between investors and borrowers. In the colonial period, there were no banks to serve this intermediary role and therefore creditors often dealt with debtors directly. Thus, creditors liquidated their "savings" by means of lawsuits.

Colonial litigation crises might therefore be characterized as predecessors to nineteenth-century bank runs. In bank runs, individuals withdraw money from banks both because of the greater demand for money during recessions (liquidity crises) ${ }^{364}$ and because of uncertainty as to which banks will remain solvent after the recession. ${ }^{365}$ Banks are more likely to remain solvent if depositors leave money in the bank. During bank panics, however, depositors' uncertainty as to the soundness of their banks propels them to get in line to try to withdraw their deposits so as to avoid the risk that their banks will fail. Similarly, fearing the loss of their money, creditors in colonial New England instituted lawsuits in order to be first in line to reclaim a debtor's funds.

364. See Douglas W. Diamond \& Philip H. Dybvig, Bank Runs, Deposit Insurance, and Liquidity, 91 J. POL. ECON. 401, 401 (1983).

365. See Charles W. Calomiris \& Gary Gorton, The Origins of Banking Panics: Models, Facts, and Bank Regulation, in FINANCIAL MARKETS AND FINANCIAL CRISES 109, 111 (R. Glenn Hubbard ed., 1991). 
The second reason why litigation volume was more sensitive to economic conditions during the colonial period was that there was no outof-court priority lending scheme and no bankruptcy system to enforce rules such as an automatic stay on debt collection. Priority to a debtor's assets was established according to the chronological order of litigation. The principal way to ensure priority over a debtor's other creditors during the colonial period was to institute a lawsuit against the debtor before the other creditors had done so. As mentioned, recession conditions are associated with tremendous economic uncertainty. When it was not clear whether a debtor would remain solvent and whether a debtor's other creditors had information that would lead them to sue, creditors were more likely to institute a suit simply to secure a place in line. The accumulated effect was a swamping of the courts with lawsuits.

In reassessing the impact of the court system on economic development, one may ask whether the courts were institutionally set up to minimize the negative consequences of the colonial lending system. The lack of a priority lending scheme outside of the litigation context suggests that they were not. Indeed, litigation during economic recessions in the colonial period represents a textbook case of the prisoner's dilemma outcome used to justify the existence of a bankruptcy system. An underlying goal of bankruptcy procedures is to preserve firms when their going concern value exceeds their liquidation value. Modern bankruptcy law in the United States attempts to make this calculation by halting all collection efforts within ninety days after a firm files for bankruptcy, and then independently assessing the worth of the company. If the bankruptcy judge finds that the liquidation value is greater than the going concern value, the judge then distributes the firm's assets according to the law and to a priority lending scheme. If the going concern value exceeds the liquidation value, the bankruptcy judge approves a plan to get the firm back on its feet.

In the absence of the automatic stay and priority lending scheme, a firm (or a debtor) is likely to have its assets liquidated, even in the case of shortterm financial trouble. Bankruptcy textbooks refer to this as an example of a prisoner's dilemma because each creditor acting in his own interest will liquidate his debts upon a sign that a debtor is in financial trouble, even if creditors as a group are worse off as a result. The colonial court system encouraged this problem by systematically granting creditors default judgments against debtors and executing on their property-often selling a debtor's assets at auction. Each creditor had an incentive to sue to protect himself, even though the system itself was likely to lead to more creditors being worse off than if there had been no race to the courthouse. Debtors who might otherwise have survived the recessions described in this Article 
would find their estates sold off or otherwise liquidated under the colonial court system.

A priority lending scheme gives creditors security that they will be paid in a debtor's assets before creditors with lower priority. The existence of an out-of-court lending scheme in the colonial period, therefore, would have eliminated suits brought purely because of uncertainty and to establish priority. The absence of such a scheme is a second example of a policy of the colonial courts that was not likely to have promoted economic development. ${ }^{366}$

The overall assessment of the colonial court system's effect on promoting economic growth is therefore ambiguous. Certainly the existence of a stable court system that reliably enforces contracts is a great asset to any society. Whether the colonial courts adapted in a way to promote economic growth during the first half of the eighteenth century, however, is far less clear.

\section{CONCLUSION}

In his article Critical Legal Histories, Robert Gordon characterizes the principal feature of modernization accounts of legal history as the assumption that law fulfills society's needs and that, as those needs change, law adapts to fulfill newly created needs. ${ }^{367}$ Current colonial legal scholarship fits this description. According to the current consensus, law in the seventeenth century had adapted to fulfill the needs of a relatively insular society. Economic growth changed the law needed by the society, and legal institutions adapted to fulfill the society's new needs.

There is ample evidence that this interpretation of colonial legal development is in need of revision, and not only because economic growth was episodic and, in aggregate, modest. First, that the legal changes described as characterizing modernization largely occurred during times of recession and reversion to barter suggests that legal historians have not identified the right "needs" to which the legal system was to have been adapting.

366. For further discussion of the absence of a priority lending scheme in the New England colonies, see generally Priest, supra note 24.

367. Robert W. Gordon, Critical Legal Histories, 36 STAN. L. REV. 57, $59-67$ (1984). Gordon describes five features of what he terms the "evolutionary functionalism" approach that has dominated legal history: (1) "'Law' and 'society' are separate social categories, each describable independently from the other but related to each other through various mechanisms of causal linkage." (2) "Societies have needs." (3) "There is an objective, determined, progressive social evolutionary path." (4) "Legal systems should be described and explained in terms of their functional responsiveness to social needs." (5) "The legal system adapts to changing social needs." $l d$. at 59-64. 
Second, understanding the importance of currency events to legal developments suggests that colonial legal historians have not adequately interpreted the basic sources of colonial legal development. Current colonial legal scholarship derives from a large body of work emphasizing the centrality of New England communities, particularly New England towns, to the lives of colonists. The current modernization account assumes that law emerged from within those communities, adapting to their changing needs. These legal historians have overlooked the fact that litigation trends and changes in the types of contractual obligations litigated can largely be explained as a response to legislation formed in the struggle between the upper levels of colonial governments and English authorities.

Finally, the history of currency events in the first half of the eighteenth century suggests that legal institutions did not adapt optimally to changing societal needs as indicated by modernization narratives. During the period from 1710 to 1750, the English government, the Massachusetts legislature, and the courts each enacted policies that worsened an already unfortunate economic situation. The English government's decision to recall all but $£ 30,000$ in government bills of credit was excessively harsh, imposing deep costs on the colonies, however beneficial to English creditors. Moreover, the strict application of the nominalism doctrine was highly problematic, as was the absence of a priority lending scheme that might have reduced the volume of litigation propelled by uncertainty during times of severe recession. Although by reducing reliance on barter and money substitutes, the colonial currency experiments brought the colonial economy one step closer to the modern, New England colonial law can be characterized as having established, at best, an uncertain foundation for the later development of a more modern economy. 
$* * *$

HeinOnline -- 110 Yale L.J. 1406 2000-2001 